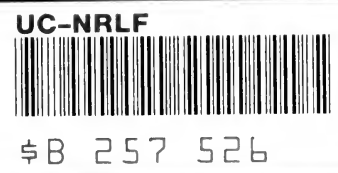



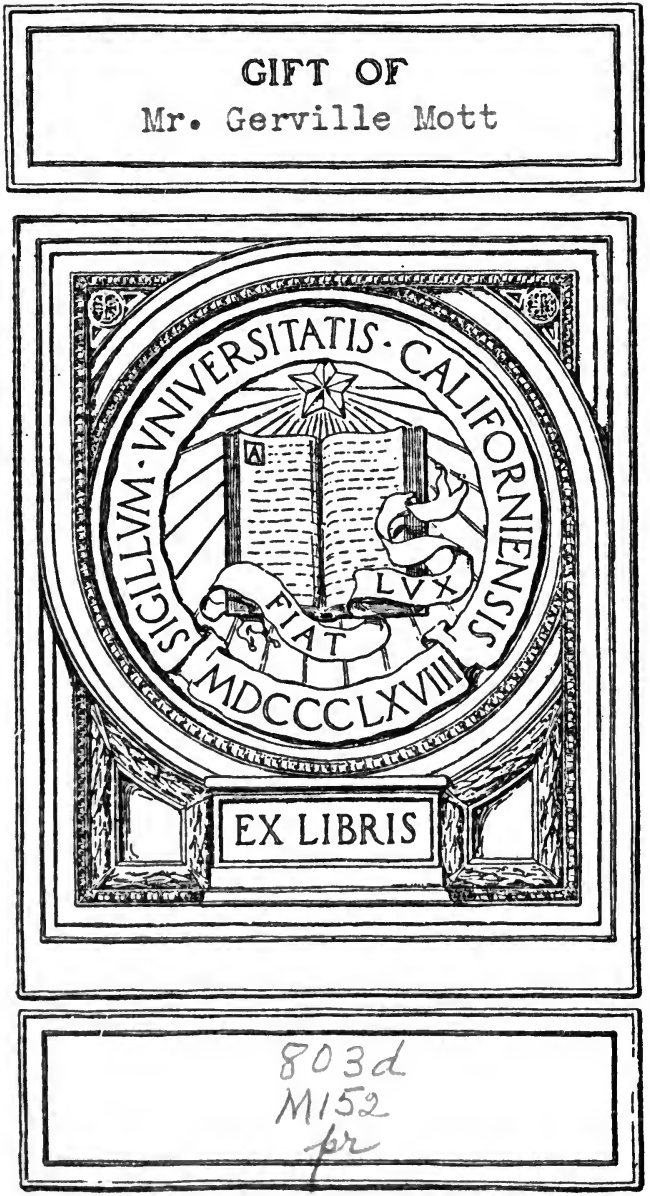
0,50 



\section{PRACTICAL \\ FRENCH PHONETICS}





\section{PRACTICAL}

\section{FRENCH PHONETICS}

\section{BY \\ T. MACIRONE}

PROFESSOR OF FRENCH PHONETICS IN THE FRANCO-ENGLISH GUILD, PARIS
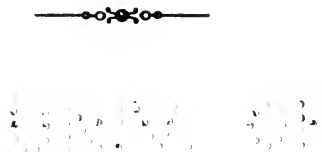

$\because \vdots \vdots \cdots \cdots \cdots$

ALLYN AND BACON

BOSTON NEW YORK

CHICAGO

ATLANTA

SAN FRANCISCO 
COPYRIGHT, 1921.

BY T. MACIRONE

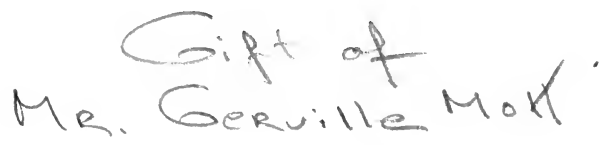

Normood 解ss

J. S. Cushing Co. - Berwick \& Smith Co.

Norwood, Mass., U.S.A. 


\section{PREFACE}

This book aims to help students of French to overcome the difficulties which confront them when they try to acquire a correct pronunciation of that language. It is the result of many years' successful experience in teaching phonetics to American students. The author is thoroughly familiar with the difficulties of pronunciation which they encounter, and understands how to lead them to acquire a good French accent.

The book discusses the principles of voice production, illustrates by means of two cuts the organs of speech, and gives the exact position of these organs in making each French sound.

It devotes a chapter to the vowels and one to consonants, giving the phonetic symbol for each sound with a paragraph explaining its use. One chapter is devoted entirely to daily exercises for the pupil's practice. Another is given to phonetic transcription of French stories and poems, the same piece of literature being presented in two columns, side by side, one in the regular Roman print and the other in the phonetic alphabet.

The vocabulary at the end furnishes the student with the meaning of every French word and idiom occurring in the chapter on phonetic transcription.

August 1, 1921.

\section{$\bar{M} 442$ iii 35}


Digitized by the Internet Archive in 2007 with funding from Microsoft Corporation 


\section{CONTENTS}

CHAPTER

PAGE

I. What Phonetics Does . . . . . 1

Advantages of Phonetics $\quad . \quad$. $\quad . \quad$. 1

Disadvantages of the Old Method . . 2

Physical Differences . . . . . 3

The Mouth . . . . . . . 4

Phoneties in Europe . . . . . . . 6

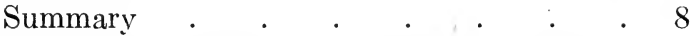

II. Formation of the Mouth and Throat. Speech

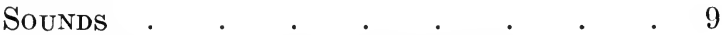

Distinctions in French and English $\quad . \quad 9$

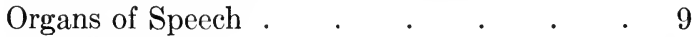

Speech Sounds

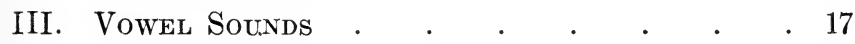

Variety of Vowel Sounds . . . . . 17

French Vowel Sounds . . . . . . 18

Nasal Vowels . . . . . . . . 30

Summary . . . . . . . . 34

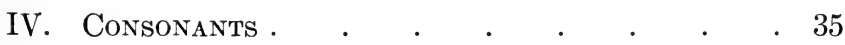

Voiced and Voiceless Consonants . . . . 35

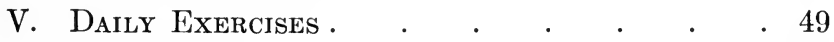

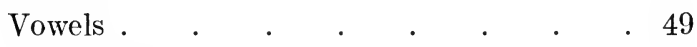

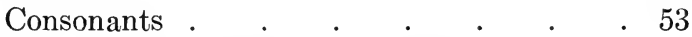

VI. Phonetic Transcription of French Stories and Poems . . . . . . . . $\quad . \quad 57$

La bonne femme et son biquet . . . 57 
Histoire du petit Chaperon Rouge . $\quad .59$ Le violon magique $\quad . \quad$. $\quad . \quad$. $\quad .62$ Les braves gens . . . . . . 70

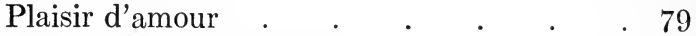
Le bon Dieu de Chemillé . . . . 87 La tarte à la crème $\quad$. $\quad$. $\quad$. $\quad$. $\quad .92$ Jeanne au pain sec $\quad . \quad . \quad . \quad . \quad 505$

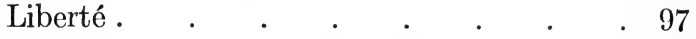

Vocabulary of Phonetic Transcription . . . . 99 


\section{PRACTICAL \\ FRENCH PHONETICS}





\section{PRACTICAL \\ FRENCH PHONETICS}

CHAPTER I

\section{WHAT PHONETICS DOES}

Advantages of Phonetics. - What are phonetic principles and what is the use of them in learning how to speak French? Phonetics teaches us exactly how we all make the sounds we utter when speaking.

It treats of sounds, not letters. It splits up every word into the sounds it is composed of and studies these sounds, one by one. Every language has a limited number of sounds, just as it has a limited number of letters, and the first thing we have to do in studying phonetics is to learn to differentiate between sounds and letters. In phonetics we study sounds for the sake of learning to speak the language of a country as the natives speak it, and we get into the habit of thinking of a word by the sounds it contains and not by the letters that represent it.

When you learn to speak a new language the sound is the unit; to try to teach a foreigner to pronounce a whole word correctly, without explaining the sounds 
it is composed of . is like trying to teach a child to do a sum in additión withou firsi teaching him his figures.

When we learn to speak French we have to learn French sounds; when we study Spanish, Spanish sounds, and so on. Very often the same sound occurs in many languages, but there are always a few unfamiliar sounds to learn in every new language we study.

Disadvantages of the Old Method. - Heretofore, the only way a foreigner had of trying to teach you how to speak his language was by repeating the word over and over again, and trusting to your ear to guide your tongue and lips into making the right sounds. But for the majority of people who have not a particularly good ear it was waste of time. The French master for instance repeated over and over again, "say tu" (thou), and the poor American student repeated "tou," and so it went on: Frenchman "tu," American "tou," or even "tjou," generally with no result whatever except. a growing indignation on the part of the Frenchman, who could not understand that the American was not purposely pronouncing it badly, and a growing despair and weariness on the part of the American.

Or take another very difficult French word, "puis" (then). How many of us have not tried in vain to satisfy a French ear with our pronunciation of the sound in the middle of that word? It should be "puis," and the American, simply because no one has 
ever explained the real difference to him phonetically, keeps on saying "pouis."

Or âgain the French $r$. You know that the letter $r$ in French must always be pronounced. Only a very small percentage of Americans pronounce all their $r$ 's, so this is always a difficulty, when you begin to speak French. We do not generally pronounce the $r$, for instance, in the word "bark," very few people say "barrk" ; and we do not pronounce it in" father." Only a very few people say "fatherrr."

Many Americans know that in French every $r$ must be pronounced, and they take endless pains to pronounce every $r$ when they are speaking French. But in English there are certain ways of pronouncing the $r$, which are so foreign to a Frenchman, that he does not even recognize it for an $r$ ! And it is so perfectly easy to pronounce the real French northern $r$, the $r$ of the cultured people in Paris, if only we know how.

That is what phonetics will teach you.

Physical Differences. - After all, there is nothing miraculous about the fact that a Frenchman utters certain sounds quite easily and that we try in vain to imitate him. He has exactly the same difficulty when he tries to imitate our sounds. The reason simply is that all his life his mouth muscles have been exercising themselves in expressing certain sounds that we have never uttered, and all our lives we have been 
uttering certain sounds that he has never expressed. So when we try to imitate his sounds, we are not only hampered by our absolute ignorance of how to pronounce them, but even if by accident, or because we have a very good ear, we do hit on the right way of pronouncing them, our muscles are stiff, and do not at first respond quickly enough to the effort we demand of them. We think we cannot do it, and give it up, when, if we had only persevered, our muscles would gradually have become exercised and would have produced the required sound correctly.

There is another thing that must often have struck you among the people by whom you are surrounded in your daily life: that they do not all pronounce English words in the same way as you. Sometimes this is because they come from a different part of the country and their accent is different from yours. Sometimes it is because they have some slight defect in their speech. This defect could be overcome by a knowledge of phonetics. It probably comes from some slight difficulty the speaker had as a child in pronouncing certain sounds, and this difficulty can in nearly every case be overcome. We need only to study sufficiently how we ourselves pronounce the sound, and how it should be pronounced.

The Mouth. - You must get into the way of studying the inside of your mouth and throat, of trying to feel, when you cannot see in the glass, exactly where 
you put your tongue to utter certain sounds: whether it touches your teeth or your palate, and where it touches them, or if it touches nothing at all, what its position is in your mouth.

If you wish to do this very thoroughly, for instance for learning several foreign languages, Spanish perhaps as well as French, or for correcting some mistake in your own pronunciation, it is a good plan to use an artificial palate for your investigations. You place it in your mouth, as a test, when you wish to know if you are putting your tongue in the right position; for the greater number of the consonants are pronounced with the tongue touching the palate more or less. The artificial palate shows you exactly where your tongue touches it, and if your position is wrong, you correct it. ${ }^{1}$

${ }^{1}$ Mr. Dumville in his admirable book, "Elements of French Pronunciation and Diction," published by Dent, London, explains how this can be done. He says: "The student who takes interest in the examination and comparison of different sounds would do well to get an artificial palate made; by its means many interesting experiments can be performed. This useful piece of apparatus can be cheaply constructed by a dentist, or a person of an ingenious turn of mind can make one himself. The following directions may be useful :

"Get a few cents worth of beeswax. Place it in a small pot, and put the pot in warm water until the wax is just soft. Remove it and place it on an oval piece of wood or a large spoon, of a sufficient size to cover the breadth of the teeth. Place the spoon in the mouth, and bite down hard on the wax. Then remove carefully from the mouth, and allow the molding to cool and harden. Place it in a small round tin box, the sides of which are a little higher than the molding, and having greased the inside of the box, pour on plaster of Paris. Leave for a few hours, then remove the wax carefully 
Phonetics in Europe. - Phonetics has been very much used for years in many European countries, with the best results. There are many schools in England where the children do not see French written in ordinary spelling for a whole year after they begin to study it. They do systematic phonetic exercises every day from the outset, and so their muscles are trained while they are young and supple; and they are very quickly able to pronounce the French sounds as well as the English. This is the case in a constantly growing number of English schools. ${ }^{1}$

from the plaster. A good impression of the inside of the mouth should appear.

"On this an artificial palate can be made by first greasing it and laying on strips of filter paper (or thin blotting paper) soaked in gum. The addition of a little powdered chalk will help to give solidity, though it is not desirable to make the palate thick. Allow the gum to dry and then after cutting off unnecessary corners and seeing that the artificial palate does not extend any farther back than the hard palate of the mouth, it can be covered with several thin coats of black enamel or Japan black. It is now ready for use. By covering the lower side with powdered chalk and placing it in the mouth, it is possible to see where the tongue touches for any articulation, for the powder will be removed by the moisture of the tongue."

1 If ever you have the opportunity, go and see for yourself at the Perse School, Cambridge. The boys there have been trained in phonetics for many years, and their pronunciation is remarkable. During the entire first year they read and write in phonetics. This prevents them from ever being led astray by the letters that are not pronounced in ordinary spelling. The sounds are explained to them in detail; they sing and say them every day. They write the words they learn in phonetics, so that they are never tempted to pronounce them badly. Because in phonetics we write only the sounds we pronounce, spelling becomes written speech, which it never is in any language now. 
Spelling in every tongue has become conventional, letters are pronounced in many different ways, and it is only custom that teaches you how to pronounce them. In phonetics every sound has its own sign, and every sign is pronounced in one single way, so that it is not possible to make a mistake. But still, even for people who have not been so fortunate as to have been taught in this way from the beginning, much can be done by phonetics. ${ }^{1}$

When the American army went to France, the men had all kinds of trouble with the language. Many soldiers will tell you how difficult they found it to make themselves understood. They knew the words, they could readthe papers, but when it came to pronouncing the yords, no one knew what they meant. They had never learned French pronunciation, except in the way it is spoken of at the beginning of this chapter ; that is to say, they had tried to imitate their teacher. And as we have said, in the majority of cases this leads practically nowhere.

Just think for a minute what a drawback a bad accent is. It puts you at an immediate disadvantage with a foreigner. He listens to you with something

1 The author once had an Italian pupil at the phonetics class of the Versailles Holiday Course for Foreigners, who had for many years pronounced the French nasal vowels (bon, en, etc.) like an English $n g$, in sing for instance. When it was explained to her phonetically how they ought to be pronounced, she corrected herself in a week. It made a great difference, as the nasal sounds are constantly occurring in French, and when wrongly uttered they made her accent very disagreeable. 
very much like contempt. You seem to him to be talking either like an ignorant man or like a child, and the association of ideas between a bad accent and ignorance or childishness is so close that he finds it practically impossible to treat you as he would an equal. Think what a pity this is, when it merely needs a thorough mastery of phonetics to put our children on an equal footing with the foreigner whost language they are learning.

Summary. - To sum up the ideas contained in this opening chapter: the new light that the study of phonetics has brought to the teaching of a foreign language is that we must begin by studying the sounds of which that language is composed before we try to join those sounds together into words. We must begin at the beginning as a baby does. We must learn to think in sounds.

This new faculty of studying sounds may be a material help to us in other ways, for instance, in correcting any mistakes we may make in our own language. No one is too old to study phonetics. It is a very simple new science which clears away the old difficulties of understanding between men of different tongues.

A bad accent in a foreign language puts you immediately in a false position with regard to the foreigner. He treats you like a child, because you sound to him like a child. He cannot realize that you have the same education and attainments as himself. 


\section{CHAPTER II}

\section{FORMATION OF THE MOUTH AND THROAT.}

SPEECH SOUNDS

Distinctions in French and English. - When you learn to speak French, the first thing to be clearly understood is that hardly one single sound is to be pronounced exactly the same as in English. Each consonant and each vowel has its own peculiar pronunciation, and this pronunciation is not the same as for the corresponding consonants and vowels in English. To take a common example: the letter $a$ in French is never pronounced as in "cat," or as in "wall," or as in "hate," and never quite the same as in "father." It is perhaps this last category which is the most likely to lead you into error, as the French $a$ in "pas" (not), for instance, will seem to you, until you have had your ear trained a little, the same as in father; but it is not so.

Organs of Speech. - Now in order to understand how to pronounce these new French sounds, we must first realize how we pronounce our own English sounds, and study the formation of the inside of our mouths and throats. We all know, of course, in a superficial way, what they are like, and we probably all know the 
few things about to be mentioned here, but everything depends on these ideas being perfectly clear and quite present in our memories.

Begin by taking a pocket mirror and looking at the inside of your mouth and throat, standing with your

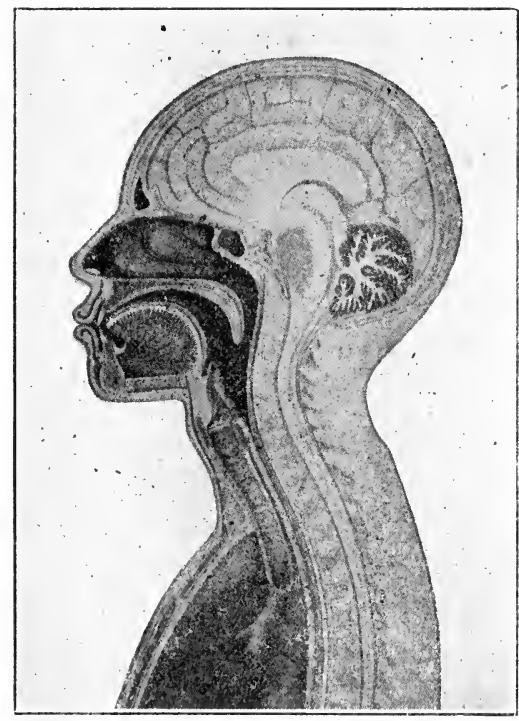

Cross Section of Head and Throat. back to the light, so that the rays of light may strike the mirror and light up your throat. What do you see? Here is a diagram to help you.

Look at the illustration for a few minutes to get quite accustomed to it. You must imagine that your head has been cut in two from top to bottom, and that you are looking at one half of it, from the side. This gives you a much more definite idea of your organs than you can have by looking at them from the front, because then you see only the end of your tongue, the surface of your palate, etc.

Now notice the things with which you are most familiar, the outlines of the head and face, the nose, 
the lips, and then begin to examine the inside of all these. Do you recognize the tongue, the large muscle

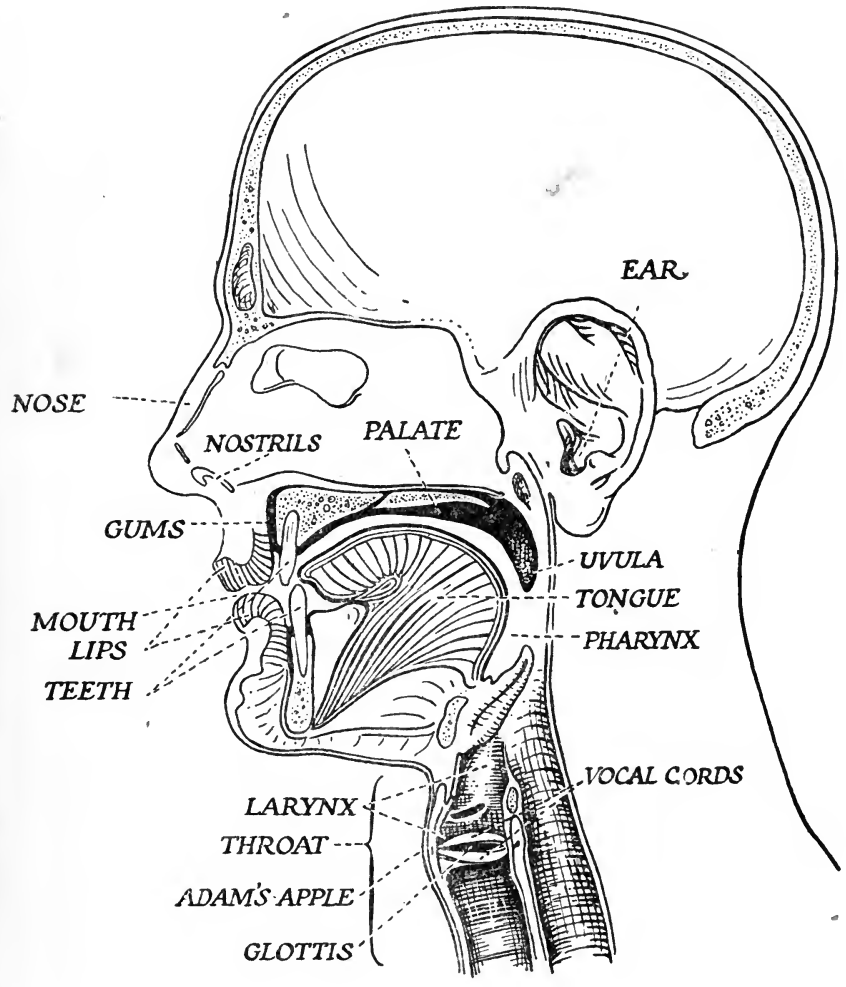

curled up in the front of the mouth? Do you see that it is joined to the bottom of your mouth for a long way? It is not simply a kind of finger, joined at one end, as we so often imagine. It can take many, many 
different shapes in your mouth. Move it about with your fingers, backwards and forwards, and from side to side, so as to be quite sure of this. Put it as far back as you can, touch your palate all over its surface with your tongue. For all these investigations, it is best to go into a room alone, where you will not mind making faces, and where you will be free to pronounce any sounds you like without being laughed at.

Now do you see the palate in the illustration? Do you see that it is a kind of wall, separating your mouth from your nose? It is the floor of the nose, and the roof of the mouth at the same time. Do you see that it has a hard bone inside in front, near your lips, but that at the back it has no bone; the bone comes to an end? Run your finger along it inside your mouth to make sure of this, and then try to touch the soft part at the back. You will find you can't, as it is too sensitive, and touching it will tend to make you feel queer.

This soft end of the palate is called the soft palate or uvula, and you can see it very easily in the looking glass. Stand with your back to the light, open your mouth very wide, as wide as you can, and say "Ah!" several times. You will see the soft end of the palate hanging down at the back of your mouth. When you say "Ah!" your tongue will lie at the bottom of your mouth, and will allow you to see the back very clearly.

Now, when you say "Ah!", exactly what do you do? Have you ever thought that your mouth and 
throat are a most wonderful musical instrument? You do instinctively without any effort what men have had great trouble to produce in a musical instrument. The breath comes out of your lungs up the windpipe, passes through the larynx, between the vocal cords, and so out through your mouth or through your nose, or through both. Your nose or your mouth are like the body of a musical instrument, of a trumpet, for instance, or a horn. It is there that the air circulates before passing out between your lips or through your nostrils.

Think of all this for a minute. Look at the illustration; find the windpipe and the larynx, with the vocal cords stretched across it, looking like a little mouth. See how the air is able to pass either through the mouth or through the nose or through both. This is because of the flexibility of the uvula, that soft end of the palate which we were talking about just now. You can move it tight against the back of your throat, and so force the air out through your mouth, or you can bring it down and allow the air to go out wholly or partly through your nose. If we make all the air pass out through the nose, we bring the uvula right down to meet the tongue behind; but we do not often do this.

We are so used to moving the uvula up and down like this, that we do not notice it, but in studying French sounds, we must notice it. We must try to become conscious of its movements, to know without 
looking in the glass when the uvula is up, pressed against the back of the passage leading into the nose (the pharynx), and when it is down, allowing the air to rise into the nasal cavity. Also, we must learn how to raise and lower it at will. It is quite easy after a little practice to feel it moving, and to control its movements.

Now we must think for a few minutes about the vocal cords. You can see them in the picture, and you must try to locate them in your own throat. They are fibers of elastic ssue stretched across the larynx. At certain times, as the air comes out between them, it makes them vibrate. If we sing, they vibrate very much. When we are at rest, breathing quietly, they lie quite loose, and the breath passes out between them with hardly any sound at all. Listen to yourself breathing for a minute: breathe harder, as when you have run a long way, and you will hear a louder sound.

The top of the windpipe, which contains the vocal cords, is a little larger than the pipe itself. Feel it by rubbing your hand against the front of your neck, where your Adam's apple is.

Keep your finger against the larynx, sing a few notes, and let your ear convince you that the sounds you produce originate exactly at that spot. Sing them softly and locate the sound. Do this several times, then speak a few sentences, and see if you can notice that certain sounds cause this vibration in the throat, and certain others do not. Pronounce, for instance, the 
word "bake." Say it very slowly in two syllables, $b a-k e, b a-k e, b a-k e$. Say it several times, and notice how the vibration in your throat stops before the $k$. Put your fingers over your ears, while you are doing this, and you will hear it better. Now you have found out that you make two different kinds of sounds when you speak, some with vibration of the vocal cords, and some without vibration. We shall examine this more closely presently (page 35 ).

Speech Sounds. - Remember that we are speaking of speech sounds, and not of letters. These are two very different things.

Very often a single sound is not represented by a single letter ; for instance, in the word " cough" there are five letters, and only three sounds, a $k$, a sort of $o$, and an $f$, kof. You may say, if you like, that ou represents the sound $o$, and $g h$ the sound $f$. In each case two letters represent one single sound.

And again a single letter may represent two sounds, and not always the same two sounds; for instance, $x$ in " box" represents a $k$ and an $s$, boks; and $x$ in " examine" represents a $g$ and a $z$, egzamine.

It is well here to spend a little time getting used to the idea of the difference between the sounds and letters in words. Take a number of ordinary words, and count the number of sounds they contain, and compare this with the number of letters they contain.

French is like the English in this respect: words are 
no longer pronounced as they are spelled. Spelling is one thing and pronunciation is another, and here we are studying pronunciation. In the exercises at the end of the book (page 49), you will pronounce every single sound you see represented. The signs and letters we are going to use represent sounds.

Let us first examine the difference between the vowel sounds and the consonants. When we pronounce a vowel sound, for instance, a as in "father," the breath passes out without meeting any obstacle in its way. When we pronounce a consonant sound such as $b, d, g, v$, our breath no longer passes out freely; it is hampered in its passage through the mouth; as in be, do, go, vie. Sometimes it is the lips that prevent the breath passing out for a minute, as in be, or it is the tongue pressing behind the teeth, as in $d o$, or the tongue presses farther back against the palate, as in go, or it is the teeth pressing against the lip, as in vie. But in each case one of the organs of the mouth intervenes to prevent the breath passing out freely. 


\section{CHAPTER III}

\section{VOWEL SOUNDS}

Variety of Vowel Sounds. - We are going to study the vowel sounds first. Pronounce all the ones you know, $a$ as in cat, wall, father, hate; $e$ as in hen, there, women; $i$ as in in (which is the same sound as that of $e$ in women), and in bite, etc. How is it that these vowel sounds differ so much, and how is it that we can make so many of them? In other languages there are many, many more. In fact there is no reason why there should not be an unlimited number of them. Have you heard people speak who come from many different states, and have you noticed how very differently they pronounce their vowel sounds? If there is such diversity of sounds in English alone, how many do you imagine you would hear all over the world?

What is the secret of this? We have only to vary the shape of our mouths ever so little to vary the sound produced. And as the mouth with the lips and cheeks is very elastic, we can imagine them taking an indefinite number of shapes and therefore forming an indefinite number of sounds.

Now let us prove this. Open your mouth wide, lay your tongue flat, and say "Ah!" Then without 
moving your tongue, begin to push your lips out, and go on trying to say "Ah!" and you will find that the sound will gradually resolve itself into "ou," without any wish of yours. That is to say, the sound changes as soon as you change the shape of your mouth. Pull the corners of your lips back as you do when you smile, put your lips together without closing them, and raise your tongue in the front of your mouth, and the sound will become ee, as in the word "feet." Now try to let some of the air get into your nose, that is, bring down the uvula a little, and you will hear a nasal sound in your vowel. Perhaps you will not be able to do this at first, or perhaps you habitually do it in the pronunciation of all your vowels. This is a very common mistake to make. In English the nasal is regarded as a disagreeable tone. If you are in the habit of speaking with a nasal tone, you will not at first be able to produce a pure mouth vowel, as you must learn to do in French.

French Vowel Sounds. - In America we very often pronounce two or three vowel sounds very rapidly, one after the other, producing what is called a diphthongal sound ; for instance, when you say " hate," you really say hay-eat, very rapidly. When you say "boy," you really say baw-ee, very rapidly. When you say "light," you really say lah-eat, very rapidly. In French you must never do this. All the vowel sounds consist of one single sound. Be very careful of this. 
We are going to give each French sound a sign to represent it, so that when reference is made to any particular sound you may be quite sure exactly which one is meant. We shall put after the explanation of each sound the different ways in which it is spelled.

We are going to take the vowels in a certain definite order, beginning with those that are pronounced in the front of the mouth, with the tongue in front, ano ending with those that are pronounced at the back of the mouth, with the tongue drawn up behind.

i. - The first vowel sound is i. Put your mouth in a smiling position almost closed; tighten all the muscles of your cheeks, somewhat as if you were going to. bite very hard; put your tongue in the front of your mouth and raise the tip of it a little, pressing it firmly against your teeth. As you are pronouncing i, be sure that all your muscles are quite still. If they move ever so little, as they often do in speaking English, in pronouncing the kindred sound $e e$ in "feet," you will have a diphthongal sound such as was spoken of just now. These diphthongal sounds are not French, and are extremely disagreeable to a French ear.

This $\mathbf{i}$ is the regular sound of $i, \hat{\imath}$, or $y$, as in $\operatorname{hardi}(s),{ }^{1}$ bold; île, island; lycée, high school.

1 Many of these different spellings of the vowel sounds may be followed by an $s$ as a sign of the plural; this $s$ is only occasionally sounded for the salie of euphony before a vowel. 
It is also the sound of $i$ in various combinations, such as $i e, i s, i t$, ient, $i x$.

comédie(s), comedy. $i l$ finit, he finishes. $t u$ finis, thou finishest. ils scient, they saw.

dix, ten (when the $x$ is not sounded).

The exercises on this sound and all the following ones will be found beginning on page 49. They should all be pronounced every day, as many times as possible. At first the jaws and muscles should ache after each exercise.

e. - This sound is very like the last. Put your mouth in the same smiling position, tighten all the muscles of your cheeks, put your tongue in the front of your mouth, with the tip raised a little and pressed against your teeth, opening your mouth a little more. This is the sound that most Americans have great difficulty in pronouncing, so great pains must be taken with it. It is very much tighter, firmer, and sharper than the kindred English sound of $e$ in " pen."

This e is the regular sound of é, as in église, church; fumée, smoke. It is also the sound: (1) of $e$ alone and in various combinations, such as $e d(s), e s, e f(s), \propto, e r$ in the infinitive of many verbs, $e z$ in the second person plural of the present indicative of nearly all verbs, et in the conjunction and (but not at the end of a great many words, like garçonnet, where the $e t$ is pronounced differently); and (2) sometimes of $a i$, for instance in the 
present indicative of avoir, in the first person singular of the past of many verbs, in the future of all verbs, and ais and ait in the present indicative of the verb savoir (this is quite exceptional).

effort, effort.

$\operatorname{pied}(\mathbf{s})$, foot.

mes, my.

clef(s); key.

Edipe, Edipus.

clocher(s), church tower.

aller, to go. (vous) allez, (you) go. et, and.

(j)'ai, (I) have.

(j)'allai, (I) went.

(j)'irai, (I) shall go.

(je) sais, (I) know.

(il) sait, (he) knows.

$\varepsilon$. - This Greek $e$ represents the sound which is generally spelled $\grave{e}$. Open your mouth fairly wide, about half as wide as you can, let your cheek muscles relax, put your tongue a little farther back than for e, and not so high in the mouth; think of a sheep bleating. This is perhaps the French vowel which comes closest to having a corresponding sound in English. It is not unlike the first vowel sound in there. Most people pronounce that vowel with two vowel sounds, that is, with a diphthongal vowel, and in French, as we have said, you must never do that. Instead try to isolate the first vowel sound in "there" and you will have a vowel very close to the French.

This $\varepsilon$ is the regular sound of $\dot{e}$ and $\hat{e}$, as in frère, brother; trè $s$, very; bê $c h e$, spade.

It is also one of the sounds of $e$ alone and: (1) of $e$, $\grave{e}$, and $\hat{e}$ in various combinations, such as et $(s)$ (except 
the conjunction $e t)$, êt(s), ect(s), es, est, ei ; and (2) sometimes of ai, â, and of ais, ait, and aient in the imperfect and conditional of all verbs.

miel, honey.

saison, season.

bouquet(s), bunch of flowers. aîné, eldest.

forêt(s), forest.

aspect(s), aspect.

(tu) es, (thou) art.

(il) est, (he) is.

neige, snow. (j)'allais, (I) was going.

(il) allait, (he) was going.

(j)'irais, (I) should ge.

(il) irait, (he) would go.

(ils) iraient, (they) would go.

a. - This is the easiest sound of all to produce, as it is the sound we all make instinctively when we open the mouth and vocalize, letting the tongue lie flat in the bottom of the mouth. It is the sound that a baby of any nationality pronounces when it begins to talk, for this reason: it does not make any effert, it just talks, and $\mathbf{a}$ is the sound that comes. If the child is angry and screaming, it makes quite a different sound, because then it tightens its muscles and says something like i. For a the muscles are lax, the tongue is lying flat, and the vocal cords vibrate. It is not at all like $a$ in hat, which sound does not exist in French and is a sound made with the tongue fairly high in the front of the mouth, and the muscles tight. On the contrary the French a (in papa for instance), is pronounced with the tongue flat and the muscles quite loose. 
This $\mathbf{a}$ is the most usual sound of $a$ or $\hat{a}$, in papa, papa; nous allâmes, we went.

It is also generally the sound: (1) of $a$ in such combinations as as, at $(s)$; (2) of $i, \hat{\imath}, i s, i t$, ient, following $o$ in moi, etc.; and (3) occasionally of $e$. Be very careful as to this word, moi, and of other's like it, toi, roit, etc., as so many people pronounce them with a "back a" (the next sound to be considered), which is quite wrong and very unpleasant to the French ear.

(tuc) as, (thou) hast.

$\operatorname{chat}(\mathbf{s})$, cat.

femme, woman.

moi, me, I. boîte, box.

(je) vois, (I) see.

(il) voit, (he) sees.

(ils) voient, (they) see.

a. - This sound is somewhat like $a$ in "father," but it is more hollow. It is the sound spoken of just now as the "back a." Do not confuse its sign a with a that we have just had. Open your mouth very wide, as wide as you can, and draw your tongue back a little.

This $\alpha$ is the sound occasionally given to $a$, especially in nation, nation; and in all French words ending in ation.

It is also sometimes the sound: (1) of $\hat{a} ;(2)$ of $a$ in such combinations as as, at, ea; and (3) of $i$, is, ie, ids, $\hat{e}$, following $o$.

mâtin, mastiff.

bas, stocking.

climat, climate.
Jeanne, Jane.

foi, faith.

trois, three. voie, way. poids, weight. poêle, stove. 
ग. - This is what is called the "open o." On pronouncing this sound after a, the last sound treated, draw back your tongue still more, push your lips out a little, and make the whole of your mouth round, but keep it open. It is very different from the English sound of $o$ in not, for instance. The French sound must be round.

This $\mathrm{o}$ is one of the pronunciations of $o, a u$, and quite exceptionally of $u$.
col, collar.
Paul, Paul.
rhum, rum.

o. - Be particularly careful how you pronounce this sound. There are very few people in America who do not give it a diphthongal form. Look at your mouth in the mirror while you are pronouncing " boat," for instance, and see how the lower jaw moves. Say it very slowly, so as to divide your diphthong into two parts. You will find that you begin with your mouth fairly open, and end with it almost closed. There are many different ways of pronouncing " boat," varying from "ba-out," to "bo-oot," passing sometimes through other vowels on the way from the first of these sounds to the second. But that vowel is never really pure in English. That is to say, it is never a single sound from the beginning to the end; it is always a diphthong.

In French it is a pure sound, a single vowel, the vowel o. Scotch people generally pronounce it easily. Push your lips out, tighten your checks and jaw muscles, draw your tongue still farther back than for 0 , and 
utter a sound which to you will seem to be almost "oo." Sing it as often as possible. Think of your tongue. Be sure that it is quite still. You must practice this sound very often at first, because when we have to pronounce a sound that we have perhaps never pronounced before, our muscles soon get tired and relax.

This $o$ is the other pronunciation of $o$ and $a u$, as in chose, thing; sauver, to save.

It is also sometimes the sound: (1) of $\hat{o}$ and $o$ in such combinations as $o s$, ot $(s)$; and (2) of $a u$ in such combinations as $\operatorname{au}(x), \operatorname{aut}(s), \operatorname{aud}(s), \operatorname{eau}(x)$.

gros, big.

côte, hill.

$\operatorname{pot}(\mathbf{s})$, pot.

chevaux, horses. $\operatorname{artichaut(s),~artichoke.~}$ $\operatorname{chaud}(\mathbf{s})$, warm. eau $(x)$, water.

u. - This is the last of the eight elementary French vowels. Keep your muscles tight, push your lips still farther out than for o, draw your tongue a little farther back, and you will say u. (Do not think that this is the sound which is written or printed " $\mathrm{u}$ " in French; it is written "ou.") Think of the vowel in the English word "boot," and make it with lips fully rounded and face muscles tight. For $\mathfrak{u}$ the lips should be pushed out as far as possible, and the tongue drawn back as far as possible. There is very little difference between this sound and the last. The round opening between the lips should be large enough to admit the 
end and a little of the wood of a lead pencil when you pronounce $\mathbf{o}$, but only the lead when you pronounce $\mathbf{u}$.

This $\mathbf{u}$ is the regular sound for ou in such combinations as ou(s), ôu, oue $(s)$, out, oux, oup $(s)$, aoul.

$\operatorname{cou}(\mathbf{s})$, neck.

où, where.

roue(s), wheel.

tout, all. doux, sweet. $\operatorname{coup}(\mathbf{s})$, blow. saoul, drunk.

These eight elementary vowels should be pronounced every day one after the other, in the order in which they are given here. Sing them up the scale, and then sing in the reverse order down the scale. Do this several times. This will help you to vocalize more than you generally do perhaps, which is the very thing needed in French. It will also help you to keep your muscles still, while you are singing each sound, and prevent you from pronouncing a diphthong. Hold cach note as long as you can. You will find the o the most difficult to keep steady.

Another good way to keep the lips and lower jaw steady, thus preventing the pure sounds from becoming diphthongs is to put a pencil between the teeth.

Another good way is to sing each sound twice: first short, to see whether the mouth is properly shaped for it, and then long, prolonging the sound as much as possible. The more you prolong the sound without altering it, the more quickly will you train your muscles to pronounce it correctly and to find their proper 
position at an instant's notice. See page 49 for daily exercises.

Now besides these eight fundamental vowels there are four other pure mouth vowels, which are difficult to pronounce. One is the sound that in French is generally spelled "u." We have already referred to it. We shall give it the sign y. Two of the other three are spelled "eu," and the third "e." Two of them are particularly hard for Americans to pronounce correctly.

y. - This sound, in spite of its great difficulty, can be found quite mechanically in the following way. Put your mouth in the right position for $\mathbf{i}$, the first of the eight fundamental vowels; that is, draw the corners of your lips back, as if you were going to smile, tighten all your muscles, press the tip of your tongue against the teeth. Then pronounce i, slowly pushing your lips as far out as you can without changing the position of your tongue. If you follow these directions exactly, you cannot go wrong.

Put your tongue in the right position for $\mathbf{i}$, then push out your lips. You should practice many times, pronouncing $\mathrm{i}--\mathrm{y}, \mathrm{i}--\mathrm{y}, \mathrm{i}-\cdots \mathrm{y}$, and then backwards y - - - i, y - - - i, y - - - i. Keep up the vocalization without a break; do not stop your voice; do not say i, y, but i - - y, and you will hear the sound gradually passing from $\mathrm{i}$ to $\mathrm{y}$. Do it very slowly at first, so as to be sure to keep your tongue in exactly the same position. 
Another trick which will perhaps help you to find this sound is to whistle the highest note you can, the very highest, then stop whistling and pronounce y. Keep your tongue and lips quite firm. When you were whistling your highest note they were exactly in the right position for pronouncing $\mathrm{y}$.

Practice $\mathbf{i}---\mathbf{y}---\mathbf{u} . \quad \mathbf{u}---\mathbf{y}--\mathbf{-}$. See exercises on page 50 .

This $\mathrm{y}$ is the regular sound for $u$ in such combinations as $u(s), \hat{u}(s), \hat{u} t, u e(s)$, and exceptionally of $e u$, eus, eut, êt, in the past tense of the verb avoir.

$t \mathbf{u}$, thou.

(tu) fus, (thou) wast. $d \hat{\mathbf{u}}(\mathbf{s})$, due.

fût, cask.

aiguë(s), sharp. eu, had.

(j)'eus, (I) had.

(il) eut, (he) had.

(nous) eûmes, (we) had.

$\varnothing$. - This sound, which is generally spelled "eux," bears the same relation to the sound $\mathrm{e}$, that $\mathrm{y}$ does to $\mathrm{i}$. Put your mouth in the right position for e, remembering that it is almost the same as for $i$, only a little less closed; but the muscles are jus: as tight, and the tongue is still pressed against the teeth. Now push out your lips, and you will pronounce $\phi$. This sound must have a great deal of resonance. Be sure to push your lips well out. Sing it at first. Some Americans pronounce it almost correctly, but do not push their lips out far enough, so that there is not sufficient resonance. The French pronounce the sound with a great 
deal of resonance, formed in the little hollow chamber between the lips and tongue, when the lips are pushed out far enough. Sing it many times and then try again to give it as much resonance when you speak it.

Practice e-- $\phi--0,0--\phi--$ e. See exercises on page 50 .

This $\phi$ is one of the sounds for eu in such combinations as $e u(s), \propto u(x), e \hat{u}, e u t, e u x$, and occasionally eur, and oeufs.

Dieu, God.

bleus, blue (pl.).

$v œ u(\mathbf{x})$, wish.

jeûner, to fast. (il) veut, (he) wishes.

(je) veux, (I) wish.

monsieur, Sir, Mr.

œufs, eggs.

œ. - This is the other sound of "eu," the open sound. You hear it especially in the syllable "eur." It bears the same relation to $\varepsilon$ that $\emptyset$ does to e and that $\mathrm{y}$ does to $\mathrm{i}$. That is to say, if you pronounce a good $\varepsilon$ with the mouth fairly wide open, your cheek and jaw muscles loose, and then push out your lips, in a round position, you will hear œ. A great many Americans pronounce this sound quite easily. It is not very different from the vowel sound in her, only the lips must be pushed out a little and rounded. The mistake that many Americans make is to confuse this sound with the previous one, which is far more difficult to produce correctly. In that case they pronounce every " eu" œ, instead of distinguishing between them and pronouncing some œ and some $\varnothing$. 
Practice $\varepsilon---œ---$ o. $0---œ--\varepsilon$. See exercises on page 51

This $œ$ is the other sound for the combinations $e u$, cu, ue, œ.

demeure, dwelling. œuf, egg. cercueil, coffin.

$œ i l$, eye.

ə. - This sound is intermediate between $\varnothing$ and $œ$. It is more closed than œ and less firm than $\phi$. It is the sound that is habitually spelled " $\mathrm{e}$ " at the end of many French monosyllables of two letters like me, te, se, and in prefixes, às in devenir. It is practically always a short sound. Be careful to notice when " $\mathrm{e}$ " must be pronounced like this, and when it must be pronounced e.

This $\boldsymbol{\partial}$ is one of the sounds for $e$, spelled also on in monsieur, and sometimes ai.

me, me.

premier, first. monsieur, Sir, Mr.

faisant, doing.

Nasal Vowels. - We shall now speak of vowel sounds which are peculiar to French and a few other Latin tongues, namely the nasal vowels; that is, vowel sounds that have their resonance in the nose. We know (page 13) that in order to make these sounds we have to lower the uvula, that soft back part of the palate. That is why we said at the beginning that it was so important to be able to do this at will when speaking French. 
There are no nasal vowels in English. All the vowels are pure mouth vowels. That is to say, in pronouncing English vowels, the uvula is always raised against the back of the throat, and all the air resonates in the mouth. This has also been the case with all the French vowels we have studied so far.

But in the case of the next four vowels we shall study, the nasal vowels, part of the air rises into the nose, and vibrates there. This is what gives the peculiar nasal sound to these vowels. A great many people do not realize that these sounds are vowels, pure vowels, and they pronounce them with some consonantal friction in the mouth, thus bringing in the sound of $n$ or $n q$. Be careful to avoid this.

They are represented in phonetics by the sign that signifies the corresponding pure mouth vowel, with a little curve placed over the vowel.

a. - This is the nasal form of a. Open your mouth wide, draw your tongue back, and say a. Then gradually let down the uvula, till the sound becomes $\tilde{\mathbf{a}}$.

Practice $\alpha---\tilde{\mathbf{a}}, \mathbf{\alpha}---\tilde{\mathbf{a}}, \boldsymbol{\alpha}---\tilde{\mathbf{a}}$.

Continue vocalizing as when practicing $\mathbf{i}---\mathrm{y}$, and $\mathrm{y}---\mathrm{i}$. You may give a good deal of nasal resonance to this vowel. You must not raise the tongue, while lowering the uvula; you will do so, if you are not careful. Keep your tongue quite steady, and bring the uvula down towards it. The uvula must not touch the tongue, or the sound will become a con- 
sonant, like the consonant $n g$ in English. The French sound is a vowel. The organs of the mouth do not touch each other. There is no friction anywhere.

This $\tilde{\boldsymbol{\alpha}}$ is the regular sound: (1) for $a$ in such combinations as an $(s)$, anc $(s)$, and $(s)$, ang $(s)$, ant $(s)$, ean, $\operatorname{amp}(s), a m, \operatorname{aon}(s)$; and (2) for $e$ in such combinations as en, eng (s), ent(s), em, emps.

an $(\mathbf{s})$, year.

blanc(s), white.

$\operatorname{grand}(\mathbf{s})$, big.

étang(s), pond.

chant(s), song.

Jean, John.

$\operatorname{champ}(\mathbf{s})$, field. ambre, amber.

enfant, child.

hareng(s), herring.

parent(s), parent.

embaumer, to perfume.

temps, time.

paon(s), peacock.

ว. - This is the nasal form of an $o$ vowel; but it is not exactly the nasal form of $ว$, or of 0 , although it is undoubtedly nearer the latter than the former. In the

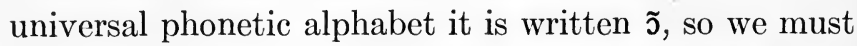
keep that sign. But do not try to nasalize an ग, nasalize an $\mathbf{0}$. Pronounce $\mathbf{0}$, and then lower your uvula, as you did to pronounce ã. Perhaps you will not find this very easy. It is a little more difficult than $\tilde{\mathbf{a}}$, because your mouth is so nearly closed that you cannot possibly see your uvula in the glass. You must try to feel it coming down. Try to pronounce $\tilde{\mathbf{a}}$, and then push out your lips, to the same position as for 0 .

Practice this $\mathbf{a}---\tilde{\mathbf{a}}---\tilde{\mathrm{\jmath}}, \tilde{\jmath}---\tilde{\mathbf{a}}---\alpha$, without 
ceasing to vocalize. When you get back to $a$, be sure you raise the uvula completely, so that there is no more nasal sound at all.

This $\tilde{\jmath}$ is the regular sound for on in such combinations as on $(s)$, ont $(s)$, ong $(s)$, ond $(s)$, om $(s)$, omp, omb $(s)$.

$\operatorname{garçon}(\mathbf{s}), \operatorname{boy}(\mathrm{s})$. pont $(\mathrm{s})$, bridge(s). long(s), long $(p l$.). nom(s), name.

compter, to count. plomb(s), lead (s).

fond $(\mathrm{s})$, bottom(s).

Be exceedingly careful to keep this a vowel sound. Do not let your tongue touch your palate at all. If you do, it. will make the sound a consonant, not a vowel.

$\tilde{\varepsilon}$. - Again this is not the nasal form of $\varepsilon$, but of the English vowel in "cat," "Ma'cm." That is to say, the mouth must be more open than for the sound $\varepsilon$. Pronounce the vowel sound in "cat," and then lower the uvula. This sound needs to be less nasalized than the two preceding ones. Do not lower the uvula so much. Do not let so much air vibrate in the nasal passages. This vowel needs to be only slightly nasalized.

Practice $\varepsilon---\tilde{\varepsilon}$, being careful to open the mouth wider in passing from $\varepsilon$ to $\tilde{\varepsilon}$.

This sound, $\tilde{\varepsilon}$, is spelled in a great many ways : in $(s)$, inq, $\operatorname{ingt}(s)$, im, yn, ym, ain(s), $\operatorname{aint}(s)$, $\operatorname{aim}(s)$, ang, $\operatorname{ein}(s), \operatorname{eint}(s)$, en $(s)$, etc. 
$\operatorname{chemin}(\mathrm{s})$, way $(\mathrm{s})$. cinq, five (when the $q$ is not sounded). $v$ ingt(s), twenty ( $p l$.$) .$ simple, simple: syntax, syntax. nymphe, nymph. main(s), hand. saint(s), saint. daim(s), deer. seing, signature. plein, full. teint(s), complexion. $\operatorname{chien}(\mathbf{s}), \log$.

œ. - This is the nasalized form of œ. All you need .to do is to pronounce $œ$ and then lower the uvula. Some phoneticians say that for œ the mouth is a little more open than for $œ$. You can do the same kind of exercises that you did for $\tilde{\jmath}$ and $\tilde{a}$; that is, pronounce $\tilde{\varepsilon}$, and then round out the lips, and you will say $\tilde{\text {. }}$.

Practice $\varepsilon---\tilde{\varepsilon}---\tilde{e}$, $\tilde{\mathrm{e}}---\tilde{\varepsilon}---\varepsilon$, being careful always to open the mouth considerably wider for $\tilde{\mathcal{\varepsilon}}$ than for $\varepsilon$. See exercises on page 53 .

This sound is spelled $u n(s), u m(s)$, eun.

$\operatorname{Hun}(\mathbf{s})$, Hun.

$\operatorname{parfum}(\mathbf{s})$, scent

jeun, fasting.

Summary. - Notice that French vowels form a series from $\mathbf{i}$ to $\mathbf{u}$. Pronounce $\mathbf{i}-\mathbf{e}-\boldsymbol{\varepsilon}-\mathbf{a}-\mathbf{a}-\mathbf{\jmath}-\mathbf{o}-\mathbf{u}$, and notice: (1) that the tongue starts in the front of the mouth and is gradually drawn back; and (2) that the lips are at first drawn back as in a smile and then are gradually pushed farther forward, till for the sound of $\boldsymbol{u}$ they are in a pouting position. 


\section{CHAPTER IV}

\section{CONSONANTS}

Voiced and Voiceless Consonants. - When we were speaking of the vocal cords (page 14), we said that certain sounds we pronounce make them vibrate, while certain others do not. We took as an example the word "ba-ke," and we noticed. that when we pronounced the first syllable $b a$ the vocal cords vibrated, but not so when we pronounced the second syllable $k e$. Why is this?

There are two groups of speech sounds; the voiced sounds and the voiceless sounds. By voiced sounds are meant those which are pronounced with vibration of the vocal cords; and by voiceless sounds, those which are pronounced without vibration of the vocal cords. All the vowels are pronounced with vibration of the vocal cords. Therefore, they are all voiced sounds. But the consonants are sometimes voiced and sometimes voiceless.

A consonant is always pronounced with a sound of friction in the mouth. When the sound of friction is accompanied by vibration of the vocal cords, it is said to be voiced; when it is not accompanied by vibration of the vocal cords, it is said to be voiceless. Vowels, on the other hand, are necessarily always ac- 
companied by vibration of the vocal cords, as they depend on the vibration for their sound ; they have no other sound, as they are not accompanied by a sound of friction.

For instance, pronounce the consonant "b." Try to pronounce it unaccompanied by any vowel sound. Do not say " be," or " bi," as in the alphabet. Isolate the sound "b." Now pronounce "p" in the same way. What is the difference between the two? In both sounds the consonant consists of a little explosion, as the lips, after being pressed closely together, are forced apart by the air escaping from the mouth. In the case of "b," the explosion is accompanied by vibration of the vocal cords. In the case of " $p$," the vocal cords do not vibrate. This is the only difference between these two consonants. Pronounce " $b$ " without vibration of the vocal cords, and you have "p"; pronounce " $p$ " with vibration of the vocal cords, and you have "b."

Take another example: the second consonant of the word "ba-ke," of which we spoke above. Is " $\mathrm{k}$ " a voiced consonant or a voiceless? Pronounce it without any vowel after it, and listen carefully. Put your finger on your larynx, in the front of the throat, as we suggested on page 14, and see if you can feel any vibration. Better still, pronounce a "k," put your hands over your ears, and listen for vibration. There is none. What is the friction that causes this consonant sound? Your tongue touches your palate almost at 
the place where the hard bone leaves off, and as the breath forees its way through between the tongue and the palate the sound " $\mathrm{k}$ " is heard. Some people pronounce it a little farther back and some a little farther forward. Pronounce the same sound with vibration of the vocal cords, and you will hear a hard "g." " $\mathrm{K}$ " and " $\mathrm{g}$ " are two forms of the same consonant; the voiceless form and the voiced.

There are other pairs of consonants, " $\mathrm{d}$ " and " $\mathrm{t}$," "v" and "f," " $\mathrm{z}$ " and "s," the soft " $\mathrm{g}$ " and "sh." In English there are also two forms of the sound "th," the sound in "there" and "thin."

We are going to take the French forms of these consonants one by one, as we have done for the vowels. First, however, let us consider a general principle which applies to all French consonants as compared with all English consonants.

All French voiced consonants, $b, d, g$ (hard), $m, n, v, z$, etc., are pronounced with much more voice than the corresponding English consonants. And the French voiceless consonants, $p, t, k, f$, s, etc., are pronounced with far less breath than the corresponding English consonants. You should practice constantly to acquire the ability to make this distinction.

To make your voiced consonants more'voiced, put your tongue and lips in the right position for forming the consonant. and then try to make your vocal cords vibrate before actually forming the sound. When your tongue and lips are in the right position, try to 
pronounce a kind of " $\mathrm{m}$ " or " $\mathrm{n}$," before " $\mathrm{b}$ " or " d," etc. You will hear a kind of nasal sound, formed by the breath vibrating in the nasal passages since it cannot circulate freely in the mouth because your organs are in position to pronounce the consonant. Put a great deal of energy into these exercises. Do not be satisfied until your voiced consonants have as much tone in them as a Frenchman's. It is only a matter of exercise and perseverance.

Then to make your voiceless consonants smoother, to pronounce them with less escape of breath, you should try to pronounce the corresponding English voiced consonants without voice. This seems a contradiction of terms. So it is, but the effort gives the required result. For instance, pronounce an English " $\mathrm{b}$," that is a " $\mathrm{b}$ " with very little voice, and gradually eliminate the voice, but without adding more breath, and you will pronounce the French " p."

We shall next take up the different French consonants in order.

p. - As we have just explained, this is a voiceless consonant, and therefore it must be pronounced in French with much less escape of breath than in English. When you have done what is advised above, that is to say, when you have pronounced an English "b" without voice, try putting a sheet of thin paper in front of your mouth, to see how much breath escapes. Pronounce first an English " p," and then a French p, and 
see if the paper moves considerably less for the French p than for the English; or, better still, light a very small candle, like those used on a Christmas tree, and hold the flame immediately in front of your lips. If you pronounce a vigorous English "p," the flame will probably go out; whereas, if you pronounce a good French p, that is, a very gentle one, the flame will move only very slightly. Make all the difference you can between the English "pa" and the French "papa."

b. - This is the voiced form of "p." Put your lips together as if you were going to pronounce "b," and before pronouncing it, try to pronounce an " $\mathrm{m}$ " with your lips closed, then bring them apart for $\mathbf{b}$. What you have to do is to make your vocal cords vibrate before allowing your lips to separate for the b. Your vocal cords must vibrate much more for this sound than in pronouncing English "b."

t. - Apply the same method here that we suggested for the $\mathbf{p}$. The " $t$ " is a voiceless consonant like $\mathbf{p}$. Therefore you must pronounce it with far less breath in French than in English. Pronounce an English "d " with the tongue touching the palate just behind the teeth. This is the correct position for French $t$. So pronounce an English "d" and then gradually stop vibrating your vocal cords. In English the pronunciation of " $t$ " causes quite a large puff of breath from the mouth. For the French $t$, there must be little 
of this. If you pronounce it correctly, you should feel hardly any escape of breath.

d. - This is the voiced form of t. Try the same method as for $b$. Put your tongue in the right position for English "d," and then vibrate your vocal cords as if you were going to pronounce " $n$ " before actually drawing your tongue away from the palate to pronounce $d$. That is, allow your vocal cords to vibrate as much as possible, much more than for the English "d."

k. - The same principles apply here. This is a voiceless consonant (it is generally written "c" or "qu" in French) pronounced with the middle of the tongue raised against the middle of the palate, about where the hard bone ends (see page 12). Again here there must be little escape of breath when pronouncing the French k. Pronounce an English hard "g," and then stop vibrating the vocal cords. The sound must be perfectly soft and gentle. Place your hand against your lower lip and, if you pronounce the French $\mathbf{k}$ properly, you will feel practically no escape of breath.

g. - This is the voiced form of $\mathbf{k}$. Put your tongue in the right position and try to produce a sound like the English "ng" in "sing," before letting your tongue go. That is to say, make your vocal cords vibrate as much as possible before you actually utter the sound. 
m, n. - These are of course nasal consonants, and the nasal consonants have much more resonance in French than in English.

They are of course voiced. Practice them with much energy ; make as much noise as you can. Let them vibrate in your nose. Practice them with as much reverberation as possible. Then you will gradually acquire the habit of giving them resonance as French people do.

n. - This is the third French voiced nasal consonant sound. We have one something like it in English, " ng" in words like "sing." But this is of course not pronounced like " $\mathrm{n}$ " followed by "g." It is quite a different sound, pronounced by touching the soft palate with the tongue. The French sound is not the same as this English one. It is the sound that is habitually written "gn," in words like " montagne," "agneau," etc. It is pronounced by touching the palate with the tongue but farther forward than in English. The tongue must touch the hard palate, and above all, the point of the tongue must be kept well behind the lower teeth.

Many foreigners and not a few provincial French people pronounce it $\mathbf{n j}$ instead of $\mathbf{n}$, but this is of course a mistake. You get nj in words like "opinion" and "panier." The second sound in $\mathrm{nj}$ is pronounced with the tip of the tongue raised (see page 45). That is why, in pronouncing $\mathbf{n}$ it is well to keep the tip of the 
tongue down behind the lower teeth, so as to be sure not to pronounce $\mathbf{n j}$. Also in $\mathrm{nj}$ the palate is touched farther forward, that is to say, $\mathrm{n}$ is pronounced farther forward in the mouth than $\mathrm{n}$.

w. - This is practically the same consonant as in English. It is the consonant form of $\mathbf{u}$ (see vowels). Pronounce $\mathbf{u}$ with the lips well forward, and the tongue well back, bringing your lips a little closer together, and you will have the consonant w. It is spelled $o$ in many French words ending in $o i$, for instance moi, toi, $s o i$, loi, roi, where the " $\mathrm{i}$ " is pronounced a after it. Be careful not to pronounce this " $i$ " like a after the sound w, as so many Americans do. Practice m - w - a, moi (me); $\mathbf{t}-\mathbf{w}-\mathbf{a}$, toi (thee).

ч. - This sound does not exist in English, and is very difficult to pronounce. It is written $\mathrm{u}$ because it is the consonant form of $\mathrm{y}$. It is the consonant that $\mathrm{y}$ becomes when it is followed by certain vowels, especially i. You must follow the same process as for w. That is to say, pronounce $\mathrm{y}$, the tongue and lips as far forward as possible. Bring the lips together, so that they touch lightly, and you will have the consonant $\mathbf{u}$. It is best, however, to practice the sound in another way. It is constantly followed by the vowel $\mathbf{i}$, and in this connection gives endless trouble to Americans. So practice pronouncing first the vowel $\mathrm{y}$, then the consonant $\mathrm{u}$, and then the vowel $\mathbf{i}$. The

$$
\mathrm{y}-\mathrm{u}-\mathrm{i}, \mathrm{y}-\mathrm{u}-\mathrm{i}
$$


three will glide insensibly into one another. Then prefix a consonant, for instance p.

$$
\mathrm{p}-\mathrm{y}-\mathrm{u}-\mathrm{i}, \mathrm{p}-\mathrm{y}-\mathrm{u}-\mathrm{i} \text {, etc. }
$$

Be careful to pronounce four sounds. Little by little you will eliminate the vowel $\mathrm{y}$ and pronounce the word "puis" as it should be pronounced $\mathbf{p}-\mathbf{u}-\mathbf{i}$ without any vowel between the $\mathbf{p}$ and the $\mathbf{u}$. But it is useless at first to attempt to pronounce the consonant, without beginning with the vowel that leads to it. It is a consonant that we are totally unused to pronouncing. Therefore, start by pronouncing the vowel y before attempting the consonant $\mathrm{u}$.

Practice in this way all the words in $u i$, for instance:

$$
\begin{aligned}
& \text { y - ч - i - t (huit, eight). } \\
& \text { y - ч - i - } 1 \text { (huile, oil). } \\
& \text { 1 - y - y - i (lui, he). } \\
& \mathrm{n}-\mathrm{y}-\mathrm{u}-\mathbf{i} \text { (nuit, night). } \\
& \tilde{\mathbf{a}}-\mathbf{n}-\mathbf{y}-\mathbf{u}-\mathbf{i} \text { (ennui, worry). } \\
& \mathbf{s}-\mathbf{y}-\mathbf{u}-\mathbf{i} \text { (suis, (I) am). } \\
& \mathrm{b}-\mathrm{r}-\mathrm{y}-\mathrm{u}-\mathrm{i} \text { (bruit, noise). } \\
& \mathrm{r}-\mathrm{y}-\mathrm{u}-\mathbf{i}-\mathbf{s}-\mathbf{o} \text { (ruisseau, stream). }
\end{aligned}
$$

Then leave out the vowel $\mathrm{y}$ and pronounce:
$\mathrm{u}-\mathrm{i}-\mathrm{t}$
$1-\mathrm{u}-\mathrm{i}$
$\tilde{\mathbf{a}}-\mathrm{n}-\mathrm{u}-\mathbf{i}$
$\mathrm{b}-\mathrm{r}-\mathrm{u}-\mathrm{i}$
q $-\mathrm{i}-1$
$\mathrm{n}-\mathrm{u}-\mathrm{i}$
$\mathrm{s}-\mathrm{u}-\mathrm{i}$
$\mathrm{r}-\mathrm{u}-\mathrm{i}-\mathrm{s}-\mathrm{o}$

Hyphens have been purposely left between the sounds to show you that the best way to practice the sounds is always to prolong each one before pronouncing the 
next. This insures more care and better training for the ear.

f. - There is very little to be said about $\mathrm{f}$. It is a voiceless consonant, so pronounce it gently in French.

v. - This is a voiced consonant. Pronounce it with plenty of voice. If you do not, it will sound like an $\mathbf{f}$ to a French ear. Do the same exercises as for $b, d, g$, etc. Try to vocalize, to make your vocal cords vibrate, before you take your upper teeth from your lower lip and then pronounce $\mathbf{v}$ with a great deal of energy.

s. - This is a voiceless sound. Do not hiss it so much as in English and remember that unlike the English it is generally not pronounced at the end of words in French. But there are of course exceptions to this rule.

z. - This is the corresponding voiced consonant. Vocalize it well. Do as you did for the nasal consonants. Pronounce it with a great deal of energy. It should tire you at first, if you do it with enough force. Little by little you should be able to do it with just as much energy, but without its tiring you.

S. - This is the voiceless sh sound, usually spelled "ch" in French. Pronounce it less energetically than in English, and notice that in English it is habitually preceded by the sound of " $t$ "; for instance, " (t)child," "(t)change," etc. In French this is not so. 
3. - This is the corresponding voiced consonant generally spelled " $\mathrm{j}$ " in French. In English it is the sound that is spelled " $\mathrm{g}$ " (soft) or " $\mathrm{j}$," except that in English a " $d$ " is always sounded before it ; as for example, "(d)George," " (d)James," etc. It is pronounced without the " $d$ " in the English word "leisure." Give it plenty of voice in French, or it will sound to a French ear too much like the $\int$ referred to above.

j. - This is the voiced consonant which is written " y," in English, as in "you," "yet," etc. In French it most frequently occurs to indicate the pronunciation of what is called the liquid "l" (1 mouillée). Words like "fille," "briller," must be pronounced fij, brije. This sound is also often given to " $i$," as, for instance, in "bien" = bj $\tilde{\varepsilon}$. It is the consonantal form of $\mathbf{i}$, just as $\mathbf{w}$ is the consonantal form of $\mathbf{u}$, and $\mathbf{u}$ of $\mathbf{y}$. When you pronounce $i$, your tongue is very high in the front of your mouth. If you raise it a little higher, you hear first of all a slight whistling sound, as the air forces its way between the tongue and the gums. If you raise it a very little more, you hear the consonant $j$. You must be very careful to pronounce it distinctly at the end of words ending in eil or ail. You must pronounce "soleil," solej and not simply sole, as so many Americans do.

r. - We come now to the important sound of $r$. There are in fact two r's in French: a dental conso- 
nant $\mathbf{r}$, and a uvula consonant $\mathbf{R}$. They differ from English " $\mathrm{r}$ " in that they are always distinctly pronounced.

The dental $\mathbf{r}$ is the easier to acquire. It is trilled on the tip of the tongue directly behind the upper teeth.

But the uvula $\mathbf{R}$ is more typically French. It is pronounced by trilling the uvula instead of the tip of the tongue. This is the $\mathbf{R}$ that is heard in Paris among educated people, and in most of the big towns. It is taking the place of the front $\mathbf{r}$, which is still heard in the south and in country districts. You must not confuse this $\mathbf{R}$ with the $r$ grasseyé, as it is called, by which is generally meant a disagreeable scraping of the throat substituted by vulgar people in Paris for the uvula $\mathbf{R}$.

To pronounce the uvula $\mathbf{R}$, all you have to do is to try to make the uvula more supple. Put water in your mouth and gargle frequently. You will be able to make the uvula vibrate at once in this way. Then gradually try it without water: Once you have learned how to make your uvula vibrate at will, you will easily learn how to pronounce all the different vowels and consonants coming both before and after $\mathbf{R}$.

If you find that you cannot pronounce the uvula $\mathbf{R}$ after several days of constant practice, it is best to give it up and content yourself with trilling the tongue. Both these ways of pronouncing the $r$ are French. Provided you succeed in producing a trill, it does not 
matter whether it is on the end of the tongue or at the uvula. Certain students, who persist in trying to make the uvula vibrate when they have great difficulty in doing so, succeed only in making a very disagreeable sound. But this is true of only a very small proportion of pupils. Most people find it quite easy after a little practice. Practice the uvula $\mathbf{R}$, first before the vowel $a$; then prefix the consonant $g$ to it, like this:

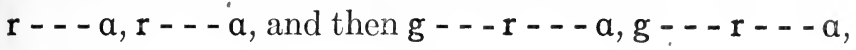
etc.

Practice the front $\mathbf{r}$, first before the vowel $\mathbf{i}$; and then after the consonant $\mathbf{d}$, thus: $\mathbf{r}--\mathbf{i}, \mathbf{r - - - i}$, d - - - r - - - i, d - - - r - - - i.

1. - This is the last consonant and it is almost as important as r. In America it is often pronounced with a good deal of the front of the tongue touching the palate, which gives a very thick sound. It should be pronounced in French with only the tip of the tongue touching the palate. If you have the artificial palate that we spoke of on page 5, Chapter I, use it freely for the practice of this sound.

In English also the tip of the tongue is curled up, and back. In French the tip of the tongue retains its natural position, downwards, and just touches the palate behind the teeth.

Begin by practicing words that commence with 1 in French: "lèvre," "liquide," "livre," and then practice, "il," " elle," "aile," etc., with 1 as the final 
sound, and try to give exactly the same sound as for initial 1. Then, little by little, introduce words that have 1 in the middle. Some of these you will find very difficult. Begin with the ones that have 1 after a vowel that is clearly pronounced, as, for instance, "balcon," "sellier," "Malvy," etc. Then come to words like "matelas" which you will find the most difficult, because in English, 1 after $t$ is almost a new consonant, as it is pronounced by many people. And in words like "matelas" in French the vowel " $\mathrm{e}$ " is so little pronounced that the 1 comes almost immediately after the $t$.

Begin by pronouncing "ma-te-las," "ma-te-lot," " cou-te-las," etc., in three distinct syllables. Little by little you will be able to pronounce them with hardly any " $\mathrm{e}$ " in the middle, as French people do, without at the same time spoiling your 1 . 


\section{CHAPTER V}

\section{DAILY EXERCISES}

\section{VOWELS}

Sing up the scale :

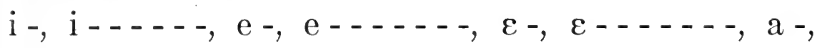
a - - - - , a -, a-- - - , $\mathrm{u}-, \mathrm{u}-\cdots-\cdots$.

Sing down the scale:

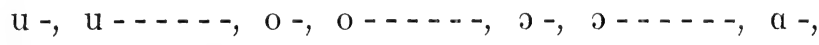

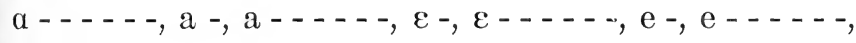
$\mathrm{i}-, \mathrm{i}-\cdots---$.

Repeat each of these two exercises at least twice.

Say, or sing on one note, the five following exercises, repeating each one at least twice:

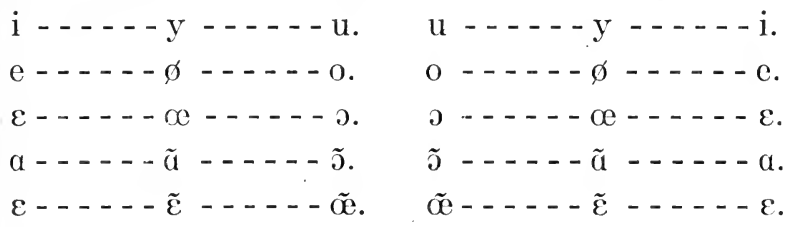

These exercises should all be pronounced carefully two or three times.

After these vowel exercises pronounce daily as many of the following sentences as you can, carrying out the 
instructions on the pronunciation of consonants given in Chapter IV. You should do some of each series every day.

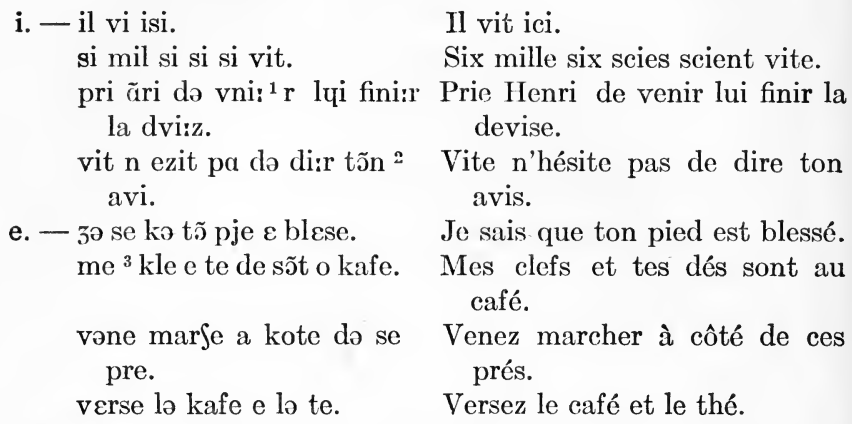

vəne marje a kote də se pre.

verse lə kafe e lə te.

Il vit ici.

Six mille six scies scient vite.

Prie Henri de venir lui finir la devise.

Vite n'hésite pas de dire ton avis.

Je sais que ton pied est blessé. Mes clefs et tes dés sont au café.

Venez marcher à côté de ces prés.

Versez le café et le thé.

I This sign is used in phonetics to indicate those syllables in which the vowel is definitely long. A vowel followed by this sign is held longer than the others. In these daily exercises we have put the quantity sign only where the length of the vowel is to be particularly marked; as the difference in quantity between the vowels is very slight, when you are pronouncing exercises slowly and with care. In these exercises all the vowels should be given full length for the sake of clearness and precision. Farther on, in the stories and poetry the quantity signs are regularly given wherever required.

${ }^{2}$ When there is a nasal vowel at the end of a word and the next word begins with a vowel also, the $\mathbf{n}$ must be sounded as well as the nasal vowel on account of the liaison. Of course this $\mathbf{n}$ is always marked in phonetics.

${ }^{3}$ There is a good deal of difference of opinion among phoneticians, as to the pronunciation of the syllable es at the end of the little words "les," "tes," "ses," etc. But we have given here the pronunciation which is most generally accepted and is considered the most modern. Some French people pronounce these words $l \varepsilon$, $t \varepsilon$, se, etc. If one cares to go into phonetics more thoroughly, he will find that there is distinctly a third sound for the letter "e" in French, intermediate between $e$ and $\varepsilon$, and this is perhaps the sound which is pronounced in these words. 
ع. - me ta te:t syr la te d oreje.

f $\varepsilon$ sə me avek sykse.

pre də mire:j sə the $\tilde{e}$ lake.

il avet yn esl pre d $\varepsilon l$.

a. - papa mo vwa lo swa:r.

lə Sa a la pat sal.

la $\operatorname{lam} d$ asje $\varepsilon$ dã la bwat.

twa e mwa nu vwajõ 1 wazo.

a. - il j a trwa pulaje dã lə bwa.

ramase la pwa:l.

lə klima $\varepsilon$ frwa.

la nasjõ ga:n.

ग. - la bon ora la bol. 1 om soldə lə kol. pol kən syr lə sol. ofra dy rom a 1 espanol dy tirol.

o. - lə po do So:d et ã o.

so:v le po:vroz animo. zano so so:v avok le so. le flo rao:s le nivo do 1 o.

u. - pu:s ta lu:rdo bu:l ver la fuil.

u:vro lə Su puir la pu:l. tu le zalu sõ de fu. vuz avez ublje le nuij.

y. - ty yz ynə bry brytal. il fy zyst ynə minyt. ma 3y:po pry:n et yze. il syfi d yno ly:t.
Mets ta tête sur la taie d'oreiller.

Fais ce mets avec succès.

Près de Mireille se tenait un laquais.

Il avait une aile près d'elle.

Papa me voit le soir.

Le chat a la patte sale.

La lame d'acier est dans la boîte.

Toi et moi nous voyons l'oiseau.

Il y a trois poulaillers dans le bois.

Ramassez la poêle.

Le climat est froid.

La nation gagne.

La bonne aura le bol.

L'homme solde le col.

Paul cogne sur le sol.

Offre du rhum à l'Espagnol du Tyrol.

Le pot d'eau chaude est en haut.

Sauve les pauvres animaux.

Jeannot se sauve avec les seaux. Les flots rehaussent le niveau de l'eau.

Pousse la lourde boule vers la foule.

Ouvre le chou pour la poule. Tous les jaloux sont des foux.

Vous avez oublié les nouilles.

Tu eus une bru brutale.

Il fut juste une minute.

Ma jupe prune est usée.

Il suffit d'une lutte. 
ф. - 3 ə v $\varnothing \mathrm{d} \phi \mathrm{z} \varnothing \mathrm{bl} \varnothing$.

se dø vjø sõ idø.

sø ki sõt œr $\varnothing$ sõ de djø.

il v $\phi$ de $\int \mathrm{v} \varnothing$ mervejø.

œ. - lœr flœ:r sõ la terœ:r de boksœ:r.

lo bœf də I avœgl ct a $\operatorname{ar} 3 \tilde{a} \operatorname{tœ:j}_{\text {. }}$

1 orgœ:j də ma sœe:r et Efferjœ:r o lœ:r.

1 œf dy z̋n doktœ:r $\varepsilon$ dã le fœ:j.

ə. - lə fəzã $\varepsilon$ səlụi də məsjø broton $\varnothing$.

il mə lə di.

nu fəร̃̃ notro promje dəvwa:r.

$3^{\partial}$ tə rədən tõ portəplym. ã. - lə bã də ta tã:t $\varepsilon$ dã lə kã.

prã 1 ãfã e se parã. за̃ s ct ãfõse dã lə $\int \tilde{a}$.

lə tã mə mãk pur Sãte se lwã:

ว. - ว̃ di kə sə gars̃̃ $\varepsilon$ poltrõ e s a fõ.

bว̃ nõbro də sõ sว̃ lอ̃.

kõt le dõ k il nu fõ.

sə mõ $\varepsilon$ lə səgõ $d \tilde{a}$ sə val profõ.

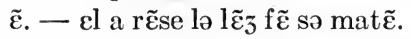

$\mathrm{v} \tilde{\varepsilon} \operatorname{sj} \tilde{\varepsilon} \tilde{\partial} \mathrm{t}$ at $\tilde{\varepsilon}$ lə $\mathrm{d} \tilde{\varepsilon}$.
Je veux deux oufs bleus.

Ces deux vieux sont hideux.

Ceux qui sont heureux sont des dieux.

Il veut des cheveux merveilleux. Leurs fleurs sont la terreur des boxeurs.

Le bœuf de l'aveugle est à Argenteuil.

L'orgeuil de ma sœur est inféricur au leur.

L'œuf du jeune docteur est dans les feuilles.

Le faisan est celui de Monsieur Bretonneux.

Il me le dit.

Nous faisons notre premier devoir.

Je te redonne ton porteplume. Le banc de ta tante est dans le camp.

Prends l'enfant et ses parents. Jean s'est enfoncé dans le champ.

Le temps me manque pour chanter ses louanges.

On dit que ce garçon est poltron et sans fond.

Bon nombre de sons sont longs.

Compte les dons qu'ils nous font.

Ce mont est le second dans ce val profond.

Elle a rincé le linge fin ce matin.

Vingt chiens ont atteint le daim. 


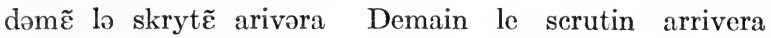
bjẽn a pwẽ. bien à point.

lə vile a pẽse la $m \tilde{\varepsilon}$ dy Le vilain a pincé la main du sakristẽ.

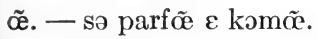
sacristain.

Ce parfum est commun.

1 œ̃bla garsõ a õ Sapo brõ. L'humble garçon a un chapeau brun.

set alæ̃ $\varepsilon t$ a kelkõ.

okõe $n$ et a $3 \tilde{œ}$.

Cet alun est à quelqu'un.

Aucun n'est à jeun.

\section{CONSONANTS}

p. - papa parl puir pol. prã la pily:l avek prekosjõ.

pj:er aporta le pryno sy:r la pla.

pe:S le pwasõ avek pasjã:s.

b. - la beg abãdon la bibl.

lo bo baba $\varepsilon$ pur lo bebe. il a bje by: 3 e $\tilde{x}$ bo purbwa:r.

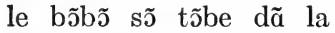
bute:j.

t. - ta tas do te gerira ta tu. ta temerite səra Satje.

$t \varepsilon$ ty frote ta te:t.

ta tãtə tə tã ynə tart.

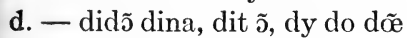
dədy d $\tilde{\varepsilon} \mathrm{d} \tilde{\text {. }}$.

la dam distribya de gã də $\mathrm{d} \tilde{\varepsilon}$.

danjelm a done yno dat bjẽ dy:r.

dimã dernje ze dezœne avek lo dyk do drezd.
Papa parle pour Paul.

Prends la pilule avec précaution.

Pierre apporta les pruneaux sur le plat.

Pêche les poissons avec patience.

Le bègue abondonne la bible.

Le beau baba est pour le bébé.

Il a bien bu: j'ai un bon pourboire.

Les bonbons sont tombés dans la bouteille.

Ta tasse de thé guérira ta toux.

Ta témérité sera châtiée:

T'es-tu frotté ta tête.

Ta tante te tend une tarte.

Didon dîna, dit-on, du dos d'un dodu dindon.

La dame distribua des gants de daim.

Daniel m'a donné une datte bien dure.

Dimanche dernier, j'ai déjeuné avec le duc de Dresde. 
k. - lə kake o kjəskə ko:z ynə kõfyzjõ.

lo kediv kryel kas de kakawet.

ze krove lə kaktys avek ma kan.

ke:l kakofoni!

g. - la gargot $\varepsilon$ grãd.

kel rəpa gargãtyesk! di gros gofret!

la garnity:r, lo gro grẽ e la gãs.

il a gane sõ gargarism.

m. - mamã m a mõtre la mod. madam la marki:z a mãke la me:s.

mime le manje:r do madam mam.

lo mimoza $\varepsilon$ mervejø.

n. - nenet $n \quad \varepsilon$ ni nigo:d ni nœrastenik.

nõ! nõ ! nõ! nə done pa notro nuga.

la bon nwazet et a la non.

nu nuõ de nø a la nuris.

n. - akõpan 1 ano a la mõta:n.

le sino sõt aline a avijõ.

de:n $m$ ãsene a swane mõ kอ̃paก๊̃.

gron, me penə twa.

w. - mwa, zo reswa trwa vilaзwa e twa œ burzwa. ty krwaz avwar frwa Se mwa.
Le caquet au kiosque cause une confusion.

Le khédive cruel casse des cacahuètes.

J'ai crevé le cactus avec ma canne.

Quelle cacophonie!

La gargotte est grande.

Quel repas gargantuesque! dix grosses gaufrettes!

La garniture, le gros grain et la ganse.

Il a gagné son gargarisme.

Maman m'a montré la mode.

Madame la Marquise a manqué la messe.

Mimez les manières de Madame Mame.

Le mimosa est merveilleux.

Nénette n'est ni niguade ni neurasthénique.

Non! non! non! ne donnez pas notre nougat.

La bonne noisette est à la nonne.

Nous nouons des nœuds à la nourrice.

Accompagne l'agneau à la montagne.

Les signaux sont alignés à Avignon.

Daigne m'enseigner à soigner mon compagnon.

Grogne, mais peigne-toi.

Moi, je reçois trois villageois et toi un bourgeois.

Tu crois avoir froid chez moi. 
El vwa l wazo syr lə pwa:l. Elle voit l'oiseau sur le poële.

3o $l$ aperswa yno fwa par Je l'aperçois une fois par mois. mwa.

ч. - pui el a esuije la sui ki Puis elle a essuyé la suie guj 1 änuije.

l'ennuyait.

el fui dy pui avek lo bui. Elle fuit de puits avec le buis.

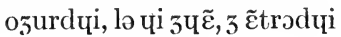

lo suis \e lüi.

sa kõduit nuit a otrui. Aujourd'hui, le huit juin, j'in-

troduis le Suisse chez lui. Sa conduite nuit à autrui.

‥ - l fu d la fore a ete fudrwaje.

İa fortyn $f \varepsilon$ la fors.

il a fete sa fest ã fevrje.

fernãd $f \varepsilon$ frirr $d \varepsilon$ fe:v.

v. - vule vu vni:r ma vwa:r?

vwaje lo vo e la va:S.

lo vwaz̃̃ ve:j dã lo vilaz də velizi.

1 volœ:r vol de vwaty:r a versa:j.

s。 - sq si sosisõ si sã sale.

n swa pa si sovaz ã sware.

la sãtinel syrve:j le si sino.

el sys dy sykrə suvã.

z. - sezar sezi lo zebr.

lo zwav zele a Swazi yn ro:z.

raze avek đo razwar $\varepsilon$ Soz Eze.

la kurtwazi e la poezi sõ do sezõ ãn azi.

S. - jãze lə Sapo də Sarl. il a SySote a la \apel. le pwa Siऽ e le \u sõ rəSerऽe.

Sãte sã fa $\Upsilon_{\ominus} \in$ lə pała. foudroyé.

La fortune fait la force.

Il a fêté sa fête en février.

Fernande fait frire des fèves.

Voulez-vous venir me voir?

Voyez le veau et la vache.

Le voisin veille dans le village de Vélizy.

Le voleur vole des voitures à Versailles.

Ces six saucissons-ci sont salés. Ne sois pas si sauvage en soiree. La sentinelle surveille les six signaux.

Elle suce du sucre souvent. César saisit le zèbre.

Lue zouave zélé a choisi une rose.

Raser avec un rasoir est chost aisée.

La courtoisie et la poésie sons de saison en Asie.

Changez le chapeau de Charles. Il a chuchoté à la chapelle.

Les pois ehiches et les choux sont recherchés.

Chantez sans fâcher le pacha. 


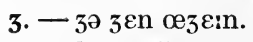

lə zardinje a dy zeni pur arãze lə zard $\tilde{\varepsilon}$.

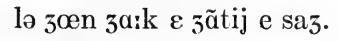

lo 3 õglœer 3 wajø $3 \varepsilon: t$ la ka:z.

j. - lə pje do la fijet va mjø. la vje:j pe:j la bje:r.

la rãtje dã la Sarmi:j $\varepsilon$ vjø.

il vjẽt a 1 ãtrotjẽ avek sõ Sj $\tilde{\varepsilon}$.

r. - il ruil sez $\varepsilon: \mathrm{r}$ avek aprəte. rjẽ ne fe pardone sə krim.

rep̃̃ avek enєrzi a tõ peir.

ri:r et agreablə lə swa:r.

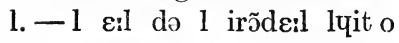
sole:j.

pəti guly! le:s la pla!

il a avale õ kilo d oliv.

lə bol $\varepsilon$ rãpli də perl.
Je gène Eugène.

Le jardinier a du génie pour arranger le jardin.

Le jeune Jacques est gentil et sage.

Le jongleur joyeux jette la cage.

Le pied de la fillette va mieux. La vieille paye la bière.

Le rentier dans la charmille est vieux.

Il vient à l'entretien avec son chien.

Il roule ses r's avec âpreté.

Rien ne fait pardonner ce crime.

Réponds avec énergie à ton père.

Rire est agréable le soir.

L'aile de l'hirondelle luit au soleil.

Petit goulu! laisse le plat! Il a avalé un kilo d'olives. Le bol est rempli de perles. 


\section{CHAPTER VI}

\section{PHONETIC TRANSCRIPTION}

la bon fam e sõ bike

il j avet yn fwa yn vje:j bən fam, ynə $\varepsilon \varepsilon: v r$ e $\tilde{e}$ Su. la Seivra s aple bike, la vje:j bon fam $\mathrm{n}$ ave pa d nõ, ni lə $\int \mathrm{u}$ nõ ply. e bike's mit

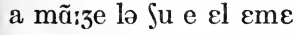
tã sa kə sa potito te:t dispary bjẽto su $1 \varepsilon$ gro:s fœ:j : " $\alpha$ ! ty sortira, biketə, biketə, $\alpha$ ! ty sortira da sə Su-la."

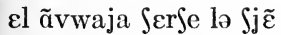
puir vniir mordro bike ; $\mathrm{m} \varepsilon$ vwala kə lə $\mathrm{j} \tilde{\varepsilon} \tilde{\varepsilon}$ nə vø pa mordrə bike, bike $\mathrm{n}$ vø pa sortir dy Su : "a! ty sortira, biketo, biketo, a! ty sortira, do sə Su-la."

el ãvwaja SerSe lə batõ pu:r vni:r batrə lə $\int \mathrm{j} \tilde{\varepsilon}$, lə batō nə vø pa batrə lə \j $\tilde{\varepsilon}$, lə $\int \mathrm{j} \tilde{\varepsilon}$ nə v $\varnothing \mathrm{pa}$ mordrə bike, bike nə
La bonne femme et son biquet ${ }^{1}$

Il y avait une fois une vieille bonne femme, une chèvre et un chou. La chèvre s'appelait Biquet, la vieille bonne femme n'avait pas de nom, ni le chou non plus. Et Biquet se mit à manger le chou et elle aimait tant ça que sa petite tête disparut bientôt sous les grosses feuilles: "Ah! tu sortiras, Biquette, Biquette, ah! tu sortiras de ce chou-là."

Elle envoya chercher le chien pour venir mordre Biquet : mais voilà que le chien ne veut pas mordre Biquet, Biquet ne veut pas sortir du chou : "Ah! tu sortiras, Biquette, Biquette, ah! tu sortiras, de ce chou-là."

Elle envoya chercher le bâton pour venir battre le chien, le bâton ne veut pas battre le chien, le chien ne veut pas mordre Biquet, Biquet ne

${ }^{1}$ This transcription should be read aloud by the pupil while the right hand column is covered up. The English translation of the French words will be found in the Vocabulary. 
vø pa sortir dy Su :

" $a$ ! ty sortira, biketə,

biketə, a ! ty sortira də

sə Su-la."

$\varepsilon 1$ ãvwaja $\int \varepsilon r \int e$ dy $f \varnothing$

pu:r vni:r bryle 1 batõ ;

lə f $\varnothing$ nə $\vee \varnothing$ pa bryle 1 batõ, lə bat̃̃ nə vø pa batrə lə $\mathrm{j} \tilde{\varepsilon} \tilde{\varepsilon}$, lə $\mathrm{j} \mathrm{j} \tilde{\varepsilon}$ nə vø pa mordro bike, bikع nə vø pa sərtir dy Su : " $\alpha$ ! ty sortira, biketo, biketo, a! ty sortira də sə Su-la." el ãvwaja Serكe do 1 o pu:r vni:r etẽ dra lo f $\varnothing$;

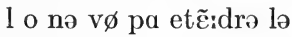
$\mathrm{f} \varnothing, \mathrm{l}$ f $\varnothing$ nə $\mathrm{v} \varnothing \mathrm{pa}$ bryle 1 batõ, le batõ nə vø pa batro lə $\int \mathrm{j} \tilde{\varepsilon}$, lə $\int \mathrm{j} \tilde{\varepsilon}$ nə vø pa mordro bike, bike nə v $\varnothing$ pa sortir dy Su : " $\alpha$ ! ty sortira, biketə, biketo, a ! ty sortira də sə Su-la."

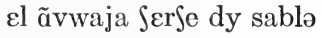
pu:r vnirr bwa:r 1 o: 1 sablo n vø pa bwa:r 1 , 1 o nə vø paz etẽ:dro lo f $\varnothing$, lə fø nə v $\varnothing$ pa bryle 1 batõ, lə batõ nə vø pa batro lə $\int \mathrm{j} \tilde{\varepsilon}$, lə $\int \mathrm{j} \tilde{\varepsilon}$ nə vø pa mordro bike, bike nə vø pa sortir dy Su : " $\alpha$ ! ty sortira, biketo, biketə, a! ty sortira də sə Su-la." veut pas sortir du chou : "Ah! tu sortiras, Biquette, Biquette, ah! tu sortiras de ce chou-là."

Elle envoya chercher du feu pour venir brûler le bâton; le feu ne veut pas brûler le bâton, le bâton ne veut pas battre le chien, le chien ne veut pas mordre Biquet, Biquet ne veut pas sortir du chou : "Ah! tu sortiras, Biquette, Biquette, ah! tu sortiras de ce chou-là."

Elle envoya chercher de l'eau pour venir éteindre le feu ; l'eau ne veut pas éteindre le feu, le feu ne veut pas brûler le bâton, le bâton ne veut pas battre le chien, le chien ne veut pas mordre Biquet, Biquet ne veut pas sortir du chou : "Ah! tu sortiras, Biquette, Biquette, ah! tu sortiras de ce chou-là."

Elle envoya chercher du sable pour venir boire l'eau : le sable ne veut pas boire l'eau, l'eau ne veut pas éteindre le feu, le feu ne veut pas brûler le bâton, le bâton ne veut pas battre le chien, le chien ne veut pas mordre Biquet, Biquet ne veut pas sortir du chou: "Ah! tu sortiras, Biquette, Biquette, ah! tu sortiras de ce chou-là." 
œrø:zmã k a s momã-la biket ave fini də mãze lo $\int u$, si bjẽ kə s n $\varepsilon$ pa biket ki $\varepsilon$ sorti dy $\int u, s$ e lə $\int u$ ki $\varepsilon t$ ãtre dã biket. $\alpha$ ! a $\mathrm{s} \varepsilon$ dro:l, $\mathrm{n} \varepsilon \mathrm{s}$ pa?

la bon fam dona õ pti ku sek sy:r la kord, puir ãpeSe biketə də gute a đ̃n o:tr Su, e tuto $d \varnothing \mathrm{s}$ ãn ale:r ve:r lœr mezõ.

\section{istwa:r $d y$ pti Saprõ ru:3}

il etct yn fwa ynə pətit fi:j k õn aple lo pti Saprõ ru:3, a ko:z də s ̃̃ zoli kapys̃̃, kulœer də səri:z. đ̃ zu:r sa mamã lui di : "ty va $t$ ãn ale porte a ta me:r grã sə po də bœir e set galet. va vit e nə $\mathrm{t}$ are:tə paz $\tilde{\alpha}$

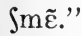

vwala dõk notrə pətit fi:j ki trotə, ki trotə, 3 yska s k $\varepsilon l \varepsilon l \varepsilon z u$ ply ru:3 kə sõ Saprõ. a s momã la el ublja $\mathrm{s}$ kə sa mamã lui ave di
Heureusement qu'à ce moment-là Biquette avait fini de manger le chou, si bien que ce n'est pas Biquette qui est sortie du chou, c'est le chou qui est entré dans Biquette. Ah! ah! c'est dròle, n'est-ce pas?

La bonne femme donna un petit coup sec sur la corde, pour empêcher Biquette de goûter à un autre chou, et toutes deux s'en allèrent vers leur maison.

\section{Histoire du petit Chaperon}

\section{Rouge $^{1}$}

Il était une fois une petite fille qu'on appelait le petit chaperon rouge, à cause de son joli capuchon, couleur de cerise. Un jour sa maman lui dit: "Tu vas t'en aller porter à ta mère-grand ce pot de beurre et cette galette. Va vite et ne t'arrête pas en chemin."

Voilà donc notre petite fille qui trotte, qui trotte, jusqu'à ce qu'elle ait les joues plus rouges que son chaperon. A ce moment-là elle oublia ce que sa maman lui avait dit

${ }^{1}$ For variety, and to enable the pupils to hear correct intonation, it is suggested that some stories be read aloud by the teacher, the French text of course being covered. 
e el s asi puir sə ropoze. "u va ty, ma potit fi:j?" lui dəmãda œ̃ gro lu ki sorte dy bwa.

"Se ma me:r grã, lui porte sə po də bœir e set galet."

"e u dəmœir t $\varepsilon l$, ta me:r grã?"

"a 1 otra bu dy bwa, e el $\varepsilon$ tut sœl, e $\varepsilon l \varepsilon$

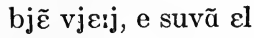
$\varepsilon$ malad, e $\varepsilon l \mathrm{~m} \varepsilon: \mathrm{m}$ boku."

"e'komã ãtrəra-ty Se

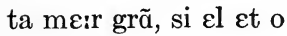
li, malad?'"

" o ! il $\mathrm{n}$ ja $\mathrm{k}$ a tire la bobinet e la Səvijet Se:ra."

tu sla $\mathrm{s}$ et $\varepsilon$ dy bavarda:3 dã:zərø, kar lə lu pri, kom ว̃ di, sع zãa a sõ ku e il ariva Se la me:r grã lõtã avã la pətit fi:j, e il sy kəmã fe:r puir uvrior la port e il mã:za la me:r grã. me:m il $\mathrm{n} \tilde{\mathrm{a}}$ fi $\mathrm{k}$ yn buङe, $\varepsilon l$ et $\varepsilon$ si pətit e si vje:j e 3 espe:r puir $\varepsilon l \mathrm{k}$ il la devora tro vit pu:r $\mathrm{k}$ \&l y lə tã do s ãn apersəvwa:r. e pui il mi lə bone do la me:r grã, tu se po:vroz abi ; il mi me:m se lynet e il sa kuSa dã et elle s'assit pour se reposer. "Où vas-tu, ma petite fille?" lui demanda un gros loup qui sortait du bois.

"Chez ma mère-grand, lui porter ce pot de beurre et cette galette."

"Et où demeure-t-elle, ta mère-grand?',

"A l'autre bout du bois, et elle est toute seule, et elle est bien vieille, et souvent elle est malade, et elle m'aime beaucoup."

"Et comment entreras-tu chez ta mère-grand, si elle est au lit, malade?"'

"Oh! il n'y a qu'à tirer la bobinette et la chevillette cherra."

Tout cela c'était du bavardage dangereux, car le loup prit, comme on dit, ses jambes à son cou et il arriva chez la mère-grand longtemps avant la petite fille, et il sut comment faire pour ouvrir la porte et il mangea la mère-grand. Même il n'en fit qu'une bouchée, elle était si petite et si vieille et j'espère pour elle qu'il la dévora trop vite pour qu'elle eût le temps de s'en apercevoir.

Et puis il mit le bonnet de la mère-grand, tous ses pauvres habits; il mit même ses lunettes et il se coucha dans 
sõ li. o bu d yn œ:r u dø õ frapa a la port. "s $\varepsilon$ mwa, votro poti Saprõ ru:3."

"zə suiz o li, malad, ma Se:r ãfã, me ti:r la bobinet e la Səvijet Se:ra."

e la potit fi:j ãtra. "mẽtonã mõto syr mõ li, puir kə $z^{2} \mathrm{t}$ ãbras $\tilde{x}$ рø."

c la patit fi:j mõta dẽ lo li.

"o ! grãme:r, dit عï, vu n e:t pa kom d abityd, kom vuz ave d grãz jø."

"s $\varepsilon$ puir mjø to vwa:r, mãn affã."

"grãme:r, kom vuz ave də gro bra!"

"s $\varepsilon$ puir mjø t sere, mõn ãfã."

"'grãme:r, kom vuz ave do grãdz oreij !" "s $\varepsilon$ puir mjø t ãtã:dro, mõn ãfã."

"grãme:r, kom vuz ave də lõ:g dã !" "s $\varepsilon$ puir tə kroke, mõn ãfã."

e lo lu sə zəta sy:r la pətit fi:j, mez, o me:m $\tilde{s} s t \tilde{a}$ õn ãtãdi dy brui ; s et $\varepsilon$ lə papa dy pəti Saprõ rui3, ki arive zyst a son lit. Au bout d'une heure ou deux on frappa à la porte. "C'est moi, votré petit chaperon rouge."

"Je suis au lit, malade, ma chère enfant, mais tire la bobinette et la chevillette cherra."

Et la petite fille entra.

"Maintenant monte sur mon lit, pour que je t'embrasse un peu."

Et la petite fille monta dans le lit.

"Oh! grand'mère, dit-elle, vous n'êtes pas comme d'habitude, comme vous avez de grands yeux."

"C'est pour mieux te voir, mon enfant."

"Grand'mère, comme vous avez de gros bras!'

"C'est pour mieux te serrer, mon enfant."

"Grand'mère, comme vous avez de grandes oreilles!" "C'est pour mieux t'entendre, mon enfant."

"Grand'mère, comme vous avez de longues dents!"

"C'est pour te croquer, mon enfant."

Et le loup se jeta sur la petite fille, mais, au même instant on entendit du bruit; c'était 'e papa du petit chaperon rouge, qui arrivait juste à 
tã puir tue net lə me $\tilde{a}$

lu. $\quad 3$ se bj $\tilde{\varepsilon} \mathrm{k}$ il arive tro ta:r puir la grãme:r,

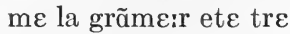
vje:j e il fo bjẽ muri:r d yn fasõ u d yn o:tr, n $\varepsilon$ s pa?

lə violõ mazik

œ̃ brav gars̃̃, nome $3 \tilde{a}$, servi pãdã trwaz ane œ̃ fermje dy:r e ava:r. lo prəmje ləve, lə dernje ku؟e, il nə rnakle dəvãt oky:n bəzən, n sə plenã zame, tuzu:r gijəre e kõtã. a la f $\tilde{\varepsilon} \mathrm{d}$ la

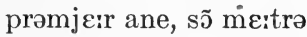
n lui dəna pwẽ də ga:3. il s dizet ã luime:m :

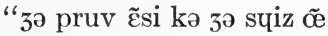
malẽ, fe pu:r komãde oz o:tr. daborr, 3 ə ga:rdə mõn $\operatorname{ar} \mathfrak{\text { ã }}$; ãsuit mõ vale, n ejã pa lo su, $\varepsilon$ bj $\tilde{\varepsilon}$ forse d reste Se mwa, e 3 ə m asy:r do nuvo sez ekselã servis. 3 ã $\varepsilon t$ ๓̃ pø sẽplə d espri ; il n reklamra pa." ãn $\varepsilon f \varepsilon, 3 \tilde{a} \mathrm{n}$ dəmãda rjẽ ; e, a la f $\tilde{\varepsilon}$ d la səgõd ane, il ã fy də me:m. o bu da trwaz ã, lo zœn om rezoly do s ãn ale. lorsk il fi pa:r d set temps pour tuer net le méchant loup. Je sais bien qu'il arrivait trop tard pour la grand'mère, mais la grand'mère était très. vieille et il faut bien mourir d'une façon ou d'une autre, n'est-ce pas?

\section{Le violon magique}

Un brave garçon, nommé Jean, servit pendant trois années un fermier dur et avare. Le premier levé, le dernier couché, il ne renâclait devant aucune besogne, ne se plaignant jamais, toujours guilleret et content. A la fin de la première année, son maître ne lui donna point de gages. Il se disait en lui-même :

"Je prouve ainsi que je suis un malin, fait pour commander aux autres. D'abord, je garde mon argent; ensuite mon valet, n'ayant pas le sou, est bien forcé de rester chez moi, et je m'assure de nouveau ses excellents services. Jean est un peu simple d'esprit; il ne réclamera pas."

En effet, Jean ne demanda rien; et, à la fin de la seconde année, il en fut de même. Au bout de trois ans, le jeune homme résolut de s'en aller. Lorsqu'il fit part de cette 
rezolysjõ a sõ me:tr, lə fermje mi la mẽ a sa pəS ; mez il n ã tira kə sõ muङwa:r a karo, dõt il sə muSa avek õ brui də trõpet.

"məsjø, di $3 \tilde{a}, 3^{2}$ vuz e fidelmã servi pãdã trwaz $\tilde{\alpha}$, e $z^{\circ}$ vøz ale vwa:r lə mõd : eje la bõte $d$ ma dəne s ki mə rəvjẽt ã tuto 3ystis." "wi, mõn ami, repãdi lə fermje, ty m a bjẽ servi, e $z^{\ni}$ v $\varepsilon$ t ã rekõpãse." il tira də sa burs trwa lja:r : "vwasi, lyi dit il, trwa lja:r tu nœf. 3 t $\tilde{a}$ don $\tilde{e}$ par ane ; səla fet yn som, e ty nə rəsəvra pa partu d osi gro ga:3." kwakə $3 \tilde{a}$ nə kəny pa tre bjẽ la valœ:r d la mone, il ã savet ase

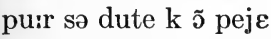
mal se servis. il regarda sõ me:trə d yn serte:n fasõ, kəm đ̃en om ki va repõdrə ; $m \varepsilon$ refleksjõ fet, il prefera nə rjẽ dirr. le diskysjõ 1 ãnuije. "tot u ta:r, pãsa t il, sə kõt sora regle." il pri le trwa lja:r e s ãn ala $\tilde{\mathbf{a}}$ Sãtã.

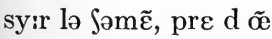

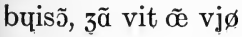

résolution à son maître, le fermier mit la main à sa poche ; mais il n'en tira que son mouchoir à carreaux, dont il se moucha avec un bruit de trompette.

"Monsieur, dit Jean, je vous ai fidèlement servi pendant trois ans, et je veux aller voir le monde : ayez la bonté de me donner ce qui me revient en toute justice."

"Oui, mon ami, répondit le fermier, tu m'as bien servi, et je vais t'en récompenser."

Il tira de sa bourse trois liards : "Voici, lui dit-il, trois liards tout neufs. Je t'en donne un par année; cela fait une somme, et tu ne recevras pas partout d'aussi gros gages."

Quoique Jean ne connût pas très bien la valeur de la monnaie, il en savait assez pour se douter qu'on payait mal ses services. Il regarda son maître d'une certaine façon, comme un homme qui va répondre; mais réflexion faite, il préféra ne rien dire. Les discussions l'ennuyaient. "Tôt ou tard, pensa-t-il, ce compte sera réglé." Il prit les trois liards et s'en alla en chantant.

Sur le chemin, près d'un buisson, Jean vit un vieux 
pətit əm, d aspe mizerable.

“ $\alpha$ ! di lə nê,, il pare kə le susi $n$ to $3 \varepsilon$ :n pa, twa!"

"purkwa səre $z^{\circ}$ trist?

3 e la, sonã dã ma

poS, me ga:zə də trwãz ã."

"e tõ trezo:r so mõst a kõbjẽ?"

"a trwa lja:r ; paz œ̃ də mwẽ."

"ekut, rəpri lə pəti vjø :

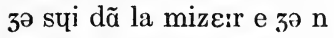
pø ply travaje. twa, ty $\varepsilon$ zœn : ty ganora fasilə-

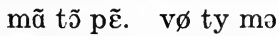
done te trwa lja:r?"

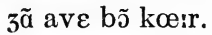

"ma fwa, dit il avek gete, $\tilde{\alpha}$ trwaz $\tilde{\alpha} z \tilde{\alpha}$ ga:nəre pøte:tr

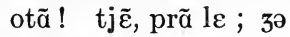
sore bjẽ mã pase."

lə $n \tilde{\varepsilon}$ rəpri :

"puiskə ty $\varepsilon$ si Saritablo, formə trwa swe : ̃ purr Sakə lja:r кә ty $m$ a done. il sərõt akõpli." 3 $\tilde{\mathrm{a}} \mathrm{s}$ mit a riir.

"kom dã le kõtə də fe, alor? e bj $\tilde{\varepsilon}, 3$ to prãz o mo. 3 ə v dabo:r yn sarbakan ki nə mãkə zame sõ by ; ãsuit œ̃ violõ kı fors a dãse tu sø ki l ãtãdrõ. kãt a mõ trwazje:m petit homme, d'aspect misérable.

"Ah! dit le nain, il paraît que les soucis ne te gênent pas, toi !"

"Pourquoi serais-je triste? J'ai là, sonnant dans ma poche, mes gages de trois ans." "Et ton trésor se monte à combien?"

"A trois liards; pas un de moins."

"Écoute, reprit le petit vieux : je suis dans la misère et je ne peux plus travailler. Toi, tu es jeune: tu gagneras facilement ton pain. Veux-tu me donner tes trois liards?"

Jean avait bon cœur.

"Ma foi, dit-il avec gaîté, en trois ans j'en gagnerai peut-être autant! Tiens, prends-les ; je saurai bien m'en passer."

Le nain reprit :

"Puisque tu es si charitable, forme trois souhaits : un pour chaque liard que tu m'as donné. Ils seront accomplis."

Jean se mit à rire.

"Comme dans les contes de fées, alors? Eh bien, je te prends au mot. Je veux d'abord une sarbacane qui ne manque jamais son but; ensuite un violon qui force-à danser tous ceux qui l'entendront. Quant à mon troisième 
swe - ma fwa, $3^{\circ} \mathrm{n}$ se ply kwa to dmãde. Swazi puir mwa."

"ty $\varepsilon$ bjẽ modere dã te v $\varnothing$, di lo nẽ. ty əra

la sarbakan e lo violõ. də ply, persə:nə nə pura to rofyze la promje:r Joz ko ty dmãdəra. sola to sora ytil avã pø." ejãt $\tilde{\varepsilon}$ si parle, lo pati vjø tira de brusa:j ynə lõ:g sarbakan e $\tilde{e}$ zoli pti violõ de pos, $\mathrm{k}$ il romit a $3 \tilde{\text { ã. }}$ "kə $\mathrm{m}$ fot il də ply?" di lə $3 œ n$ əm. il rəmersja lə $n \tilde{\varepsilon}$ e parti, mwatje kurã, mwatje dỡsã. 3 ̃̃ traversa bjẽtot õ karfu:r opre dykel il j avet ã pti bwa, e il apersy, ataJe a õen arbrə, lə Sval dy fermje, avek la karjol vid. ã me:m tã, notro vwajazœ:r ãtãdi la vwa də

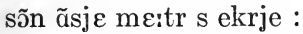

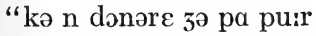
avwa:r sə me:rl ki siflə si bj $\tilde{\varepsilon}$ !"’

ejã f $\varepsilon$ kelkə pa dã lə bwa, $3 \tilde{a}$ apersy lə fermje. "e kwa ! me:tro, lui dit il, $\varepsilon: t$ vu si frijã də $\int \tilde{a}-$ sõ? 3 ว n vu save pa myzisj:̄."

- $\alpha$ ! s $\varepsilon$ twa? fi 1 o:tr $\tilde{a}$ souhait - ma foi, je ne sais plus quoi te demander. Choisis pour moi.'"

"Tu es bien modéré dans tes vœux, dit le nain. Tu auras la sarbacane et le violon. De plus, personne ne pourra te refuser la première chose que tu demanderas. Cela te sera utile avant peu."

Ayant ainsi parlé, le petit vieux tira des broussailles une longue sarbacane et un joli petit violon de poche, qu'il remit à Jean.

"Que me faut-il de plus?" dit le jeune homme. Il remercia le nain et partit, moitié courant, moitié dansant.

Jean traversa bientôt un carrefour auprès duquel il y avait un petit bois, et il aperçut, attaché à un arbre, le cheval du fermier, avec la carriole vide. En même temps, notre voyageur entendit la voix de son ancien maître s'écrier :

"Que ne donnerais-je pas pour avoir ce merle qui siffle si bien!"

Ayant fait quelques pas dans le bois, Jean aperçut le fermier. "Eh quoi! maître, lui dit-il, êtes-vous si friand de chansons? Je ne vous savais pas musicien."

- Ah ! c'est toi? fit l'autre en 
sə rəturnã. 3 ว mə susiore p $\varnothing$ də sə me:rl, si $3^{\circ}$ $\mathrm{n}$ pãse $\mathrm{k}$ a la fwa:r pro-

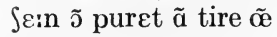
bõ pri. me ki sə Sar3əre d ale lui me:tr $\tilde{e}$ grẽ do sel syr la k $\varnothing$ ?

— zə n e pa do sel dã ma poS, ropri $3^{\tilde{a}}$; mez avek ma sarbakan zə pøz eturdirr l wazəle." ejãt $\tilde{\varepsilon s i ~ p a r l e, ~ i l ~ v i z a ~ l ə ~}$ merl a 1 eil go:s; la

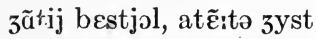
a set ãdrwa, tõba eturdi dc.4 õ fure d exin e də rõs.

"ale, me:tr, di $3 \tilde{a}$; ale ramase votr wazo!"

l ava:r sə mit a katro pat e, kom il py, sə freja $\tilde{e}$ pasa:3 a trave:r lez epin pu:r atẽdro lo merl $\mathrm{k}$ il ãtrəvwaje ; mez alo:r, sعzisã sõ violõ mazik, 3ã so mit a ã $3 w e$, e lo fєrmje sə drєsa bryskəmã sy:r se zãb. Suləve par yn fors mervejø:z, il sota, il bõdit o miljø de rõs, ki lə deङire do tut

pa:r.

"are:t! are:t! kriet-il. f $\varepsilon$ te:r set myzik dy djabl! $\varepsilon$ s isi õen ãdrwa pu:r dãse? are:t, selera!" $z^{a}$ kõtinuct a se retournant. Je me soucierais peu de ce merle, si je ne pensais qu'à la foire prochaine on pourrait en tirer un bon prix. Mais qui se chargerait d'aller lui mettre un grain de sel sur la queue?

- Je n'ai pas de sel dans ma poche, reprit Jean ; mais avec ma sarbacane je peux étourdir l'oiselet."

Ayant ainsi parlé, il visa le merle à l'aile gauche ; la gentille bestiole, atteinte juste à cet endroit, tomba étourdie dans un fourré d'épines et de ronces.

"Allez, maître, dit Jean ; allez ramasser votre oiseau!"

L'avare se mit à quatre pattes et, comme il put, se fraya un passage à travers les épines pour atteindre le merle qu'il entrevoyait ; mais alors, saisissant son violon magique, Jean se mit à en jouer, et le fermier se dressa brusquement sur ses jambes. Soulevé par une force merveilleuse, il sauta, il bondit au milieu des ronces, qui le déchiraient de toutes parts.

"Arrête! arrête! criait-il. Fais taire cette musique du diable! Est-ce ici un endroit pour danser? Arrête, scélérat!" Jean continuait à 


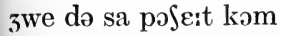
$\mathrm{s}$ il n y fet o:tro So:z tut sa vi ; e, plyz il i mete d atr $\tilde{\varepsilon}$, ply l ava:r sotet e bõdise, si bj $\tilde{\varepsilon}$ kə lez epin lui egratine I viza:3 e lui ara se se ve:təmã par lãbo. "ty a sy fizamãt ekorSe lə po:vrə mõd, pãs $\varepsilon$ nətrə 3wajø menetrje ; kə lez epin tə lə rãd!" sotã də plyz ã ply o, lə f̃̃rmje n ã puve ply. "are:t! krijet il. $3^{\text {ə tə }}$ donəre tu s kə ty vudra! yn bu:rs ple:n d or! yn burrs kə 3 e sy:r mwa!

- puiskə vuz ع:t si zene-

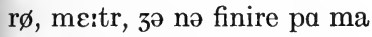
gavot, di 1 o:tr $\tilde{a}$ sesã də 3 we. $m \varepsilon$ rəsəve $m \varepsilon$

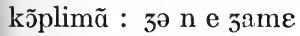
vy œ dãsœ:r osi lest." ã dizã se mo, il pri la bu:rs kə lo fermje lui tãde ; puiz il pursuivi

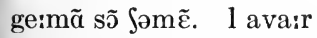
n y rjẽ də ply prese kə $\mathrm{d}$ ale lə denõse a la zystis, ã l akyzã də lui avwa:r vole sa bu:rs apre 1 avwa:r deSire avek sez õgl.

lə zœen əm fy bjẽtot arete, 3yze e kõdane a ع:tro pãdy. jouer de sa pochette comme s'il n'eût fait autre chose toute sa vie; et, plus il y mettait d'entrain; plus l'avare sautait et bondissait, si bien que les épines lui égratignaient le visage et lui arrachaient ses vêtements par lambeaux.

"Tu as suffisamment écorché le pauvre monde, pensait notre joyeux ménétrier; que les épines te le rendent!"

Sautant de plus en plus haut, le fermier n'en pouvait plus. "Arrête! criait-il. Je te donnerai tout ce que tu voudras! Une bourse pleine d'or! Une bourse que j'ai sur moi!

- Puisque vous êtes si généreux, maître, je ne finirai pas ma gavotte, dit l'autre en cessant de jouer. Mais recevez mes compliments : je n'ai jamais vu un danseur aussi leste."

En disant ces mots, il prit la bourse que le fermier lui tendait; puis il poursuivit gaîment son chemin. L'avare n'eut rien de plus pressé que d'aller le dénoncer à la justice, en l'accusant de lui avoir volé sa bourse après l'avoir déchiré avec ses ongles.

Le jeune homme fut bientôt arrêté, jugé et condamné à être pendu. 
o məmã u õ lə kõduizet a la potãs, lə fermje, ki etet o promje rã do la fu:l, lụi krija d yn vwa fyrjø:z :

"myzisjẽ də malœ:r! ty vaz ع:tr peje solõ te merit."

3ã mõta trãkiləmã le dəgre də 1 e $\varepsilon: 1$ adose a la potãs ; mez, o dernjer eSəlõ, il sə rəturna ve:r lə 3y3 :

"akorde mwa, dit il, ynə

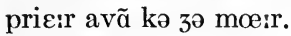

— lake:l?

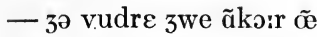
patit ع:r sy:r mõ violõ." osito lo fermje s ekrija : "nə lə permete pa, məsjø lə $3 \mathrm{yz}$ ! nə lə permete pa! — pu:rkwa, di lə zyz, nə lui akordəre 3 pa set dernje:r $3 w a ? "$

zo n sui pa sy:r kə lə mazistra yt ete osi kõpatisã, s il ave parle suivã sõ kœ:r ; me 3ã ave rəsy pu:r trwazje:m dõ kə sa prəmje:r dəmãd lui səret akorde, e, sã lo savwa:r, lə $3 \mathrm{y} z$ obeiset a $\tilde{\mathfrak{e}}$ puvwa:r ply for kə lo sjẽ. õ rãdit a $3 \tilde{\alpha}$ sõ violõ (kar õ l ave depu:je do tu s $\mathrm{k}$ il posede), e il s mit ã posty:r də $3 w e$.
Au moment où on le conduisait à la potence, le fermier, qui était au premier rang de la foule, lui cria d'une voix furieuse :

"Musicien de malheur! tu vas être payé selon tes mérites."

Jean monta tranquillement les degrés de l'échelle adossée à la potence ; mais, au dernier échelon, il se retourna vers le juge :

"Accordez-moi, dit-il, une prière avant que' je meure.

—Laquelle?

- Je voudrais jouer encore un petit air sur mon violon." Aussitôt le fermier s'écria : "Ne le permettez pas, monsieur le juge! Ne le permettez pas! - Pourquoi, dit le juge, ne lui accorderais-je pas cette dernière joie?"'

Je ne suis pas sûr que le magistrat eût été aussi compatissant, s'il avait parlé suivant son cœur; mais Jean avait reçu pour troisième don que sa première demande lui serait accordée, et, sans le savoir, le juge obëissait à un pouvoir plus fort que le sien. On rendit à Jean son violon (car on l'avait dépouille de tout ce qu'il possédait), et il se mit en posture de jouer. 
"ataSe mwa! krija lo fermje : ataSe mwa! õn eky a ki m ata\əra solidmã !" me $3 \tilde{a}$ ave done lə prəmje ku d arse : $3 y_{3}$, grefje, buro, pœpl, tu so mit a rəmue ; la kərdə

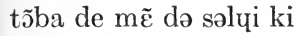
vulet ataSe lo fermje pu:r õen eky. o səgõ ku, tus loveir la 3 ãıb; e lo buro, lesã la sõ pasjã, desãdi l e $\int \varepsilon: l$ katr a katr puir dãse avek lez o:tr. o trwazje:m ku d $\operatorname{ars} \varepsilon$, tus s mirt a sote, a bõdirr, lo ริy:3 e lo fermje ã te:t, sotã ply o kə tu lə mõd. ¡œnz e vjø, graz e me:gr, tus ätret ã dãs ; le $\int j \tilde{\varepsilon} z \emptyset m \varepsilon: m$, sə dresã syir lœur pat də derje:r, bõdise sy:r plas.

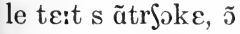
s ekraze le pje, tu lə mõd y:rle do dulœ:r. âf $\tilde{\varepsilon}$ lə 3 yz s ekrija d ynə vwa altãt :

"ase!... ase !. . . so .

. . $3^{2}$. . t akordo ta gra:s . . f fini ta myzik!" alo:r, $3 \tilde{a}$ sesa do $3 w e$, desãdi də 1 e $\varepsilon$ :l e sə fi rãdra la sarbakano e la bu:rs. il kə̃vẽki də mãsõz lə fermje ava:r, ki
"Attachez-moi! cria le fermier ; attachez-moi! Un écu à qui m'attachera solidement !" Mais Jean avait donné le premier coup d'archet: juge, greffier, bourreau, peuple, tout se mit à remuer; la corde tomba des mains de celui qui voulait attacher le fermier pour un écu. Au second coup, tous levèrent la jambe ; et le bourreau, laissant là son patient, descendit l'échelle quatre à quatre pour danser avec les autres. Au troisième coup d'archet, tous se mirent à sauter, à bondir, le juge et le fermier en tête, sautant plus haut que tout le monde. Jeunes et vieux, gras et maigres, tous entraient en danse ; les chiens eux-mêmes, se dressant sur leurs pattes de derrière, bondissaient sur place. Les têtes s'entre-choquaient, on s'écrasait les pieds, tout le monde hurlit de douleur. Enfin le juge s'écria d'une voix naletante :

'Assez!. . Assez ! . . Je je... t'accorde ta grâce . . Finis ta musique !" Alors, Jean cessa de jouer, descendit de l'échelle et se fit rendre la sarbacane et la bourse. Il convainquit de mensonge le fermier avare, qui 
fy zote ã prizõ pu:r l avwa:r fosmãt akyze. puiz il so rəmit ã rut avek lo violõ e la sarbakan, dõt il sə servit ãko:r ã mẽt okazjõ.

\section{$\operatorname{l\varepsilon } \operatorname{brav} 3 \tilde{\mathrm{a}}$}

kom le ve:r a swa $\mathrm{n}$ ave pa reysi, la bon madam pero:l so truve par azar d ase mesã:t ymœ:r ; e məsjø pero:l, rezine, la lese puse sez "ave maria" sã trop oze rjẽ dirr. - di livre də kokõ ! supire madam pero:l, pa me:m lə pri d la gre:n ; aSte-vu dõk õ Sa:l avek sa.

- kə vø ty? ãbrwazin, ty to 1 asetra 1 ane proSE:n. duz mwa sõ vit pase.

- l ane proSe:n, ki l a vy? yn So:z ã tu ka serte:n, s $\varepsilon$ kə zə n ore paz ãko:r lo Săl set ane si. $\quad$ วə $\varnothing \varnothing$ Sãte : mõ kœ:r supi:r! 3 ave purtã bjã kõte sy:r sə Sa:l. e, madam pero:l s etã ty, məsjø pero:l, ki kryt a yn akalmi, prit a fut jeté en prison pour l'avoir faussement accusé. Puis il se remit en route avec le violon et la sarbacane, dont il se servit encore en mainte occasion.

- Conte traditionnel, transcrit par Maurice Bouchor.

\section{Les braves gens}

Comme les vers à soie n'avaient pas réussi, la bonne Madame Peyrolles se trouvait par hasard d'assez méchante humeur ; et Monsieur Peyrolles, résigné, la laissait pousser ses "Ave Maria" sans trop oser rien dire.

- Dix livres de cocons! soupirait Madame Peyrolles, pas même le prix de la graine; achetez-vous donc un châle avec ça.

- Que veux-tu? Ambroisine, tu te l'achèteras l'année prochaine. Douze mois sont vite passés.

- L'année prochaine, qui l'a vue? Une chose en tout cas certaine, c'est que je n'aurai pas encore le châle cette année-ci. Je peux chanter : Mon cœur soupire! J'avais pourtant bien compté sur ce châle. Et, Madame Peyrolles s'étant tue, M. Peyrolles, qui crut à une accalmie, prit à 
œ̃ klu sõ sekatœir avek

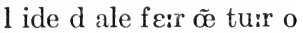
3ardẽ. madam pero:l 1 are:ta :

- le:s dõk lez arbrə trãkil, ty ora dəm̃̃ lə tã do lez eborne! o:tr fwa, sã k õ s ã mela, tu lez ä lo vje:j espalje porte. $m \varepsilon$ dəpui kə lə grã savã də pari $\varepsilon$ pase par kãtoperdri e $\mathrm{k}$ il vuz a fet o serklə set famøz kõf $\varepsilon$ rãs, dəpui $\mathrm{k}$ il a faly s abone a la rəvy $d$ arborikylty:r, tuzu:r dã tez istwa:r e te metod, te burr, te gref, te burz̃̃z a bwa, te burzõz a frui, ty kup, ty ron, ty taij . . . e zə nə se ply lə gu k õ le pwa:r?

frwase par set filipik, dõt il nə puvet a pa:r swa kõteste la jystes, məsjø pero:l kita lo sekatœ:r, tãdi kə madam pero:1 rəvənet o syz $\varepsilon$ də se doleã:s.

— tã də pe:n! e purkwa? puir rjẽ. vwala purtã d $\emptyset$ mwa kə nu nuz eksterminjõ, sy:r pje də nui kəm də zu:r, avek skolastik a ki 3 ave promi də dəne mã viø un clou son sécateur avec l'idée d'aller faire un tour au jardin. Madame Peyrolles l'arrêta :

- Laisse donc les arbres tranquilles, tu auras demain le temps de les éborgner! Autrefois, sans qu'on s'en mêlât, tous les ans le vieil espalier portait. Mais depuis que le grand savant de Paris est passé par Canteperdrix et qu'il vous a fait au Cercle cette fameuse conférence, depuis qu'il a fallu s'abonner à la Revue d'arboriculture, toujours dans tes histoires et tes méthodes, tes bourres, tes greffes, tes bourgeons à bois, tes bourgons à fruit, tu coupes, tu rognes, tu tailles... et je ne sais plus le goût qu'ont les poires!

Froissé par cette philippique, dont il ne pouvait à part soi contester la justesse, Monsieur Peyrolles quitta le sécateur, tandis que Madame Peyrolles revenait au sujet de ses doléances.

- Tant de peine! Et pourquoi? Pour rien. Voilà pourtant deux mois que nous nous exterminions, sur pied de nuit comme de jour, avec Scholastique à qui j'avais promis de donner mon vieux 
Sa:l lorskə 3 orع mõ

Sa:l nœf e ki, l ive:r prosẽ, pu:r la mes də set œ:r, dəvra sə kõtãte də sa pəlis d $\tilde{\varepsilon}$ djen . . daborr, promjer agremã: le ve:r a swa s etã tro prese $\mathrm{d}$ eklo:r, ãn avãs d yn sme:n, sãz atãdro kə lə ve:r y puse o myrje, il nuz a faly Sak matẽ, puir lœ:r nurity:r, ramase de fœej də rõs, lə lõ de fose, kom dø bəemjen. 3 ãn e ãkə:r le dwa pikote ... e apre lœ:r səgõ some:j, kã tut a ku il sõ dəvəny trist, ki عt ale, o riskə d sə presipite, kœji:r dã le roSe dy fo:r la lavãd e la marzole:n nesese:r o fymigasjõ? e tã d o:tro traka ãko:r ! . . . ãf $\tilde{\varepsilon}$ tu mar$\int \varepsilon$ bjẽ. aline sy:r lez etazє:r, me sẽkãt kabanet ã bel bruije:r də ly:r, n atãd $\varepsilon$ ply kə le kokõ. me ve:r a swa a əəvย də dərmi:r de trwa : ru kom 1 ว:r gõfle, trãsparã e suã la swa. deza il grẽpe lə lõ de brẽdi:j ; le ply brav file deza, akroSã lœ:r fil a drwat, a go: $\int$, kãt châle lorsque j'aurais mon châle neuf et qui, l'hiver prochain, pour la messe de sept heures, devra se contenter de sa pelisse d'indienne . . D'abord, premier agrément : les vers à soie s'étant trop pressés d'éclore, en avance d'une semaine, sans attendre que le vert eût poussé aux mûriers, il nous a fallu chaque matin, pour leur nourriture, ramasser des feuilles de ronces, le long des fossés, comme deux bohémiennes. J'en ai encore les doigts picotés . . E Et après leur second sommeil, quand tout à coup ils sont devenus tristes, qui est allée, au risque de se précipiter, cueillir dans les rochers du fort la lavande et la marjolaine nécessaire aux fumigations? . . Et tant d'autres tracas encore ! . . Enfin tout marchait bien. Alignées sur les étagères, mes cinquante cabanettes en belle bruyère de Lure, n'attendaient plus que les cocons. Mes vers à soie achevaient de dormir des trois : roux comme l'or, gonflés, transparents et suant la soie. Déjà ils grimpaient le long des brindilles; les plus braves filaient déjà, accrochant leur fil à droite, à gauche, quand 
$\varepsilon$ syrvony set ora:5. alo:r, o promje ku do tone:r, 3 e vy le po:vro be:t rodesãdr e voni:r muri:r sy:r lœ:r litje:r . . . $\tilde{\propto}$ dezastr! skõlastik plõere, 3 avez ãvi d ã fe:r otã.

məsjø perə:l, emy, puiza pu:r sə done kura:3 ynə dublə priz dã sa tabatje:r ãn eka:j ki grẽsa, e pãdã kعlkə səgõd, silãsjøzmã, madam pero:l, e lui s ãtrərəgarde:r. məsjø e madam pero:l, $\mathrm{u}$ - kom õ lez aple ply komynemã dã lə pe:j, ã manje:r d afekty $\varnothing: s$ familjarite - məsj $\varnothing$ viktris e madam ãbrwazin ete, dã tut la forso dy te:rm, de person də 1 ãsjẽ tã. bj kwakə trez aze (lœe:r maria:3 $\mathrm{s}$ ete fet alorr kə Sarl dis rejet ãko:r) il vive də pətit rãt, də se tut pətit rãt ki o:trofwa syfizct a kõstitye la forty:n. po:vrəz o fõ, il nə $\mathrm{s}$ ãn apersəve pa, ejã vjeji sã sə kree okõ de

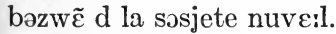
e ilz etct œr $\varnothing$, a la manje:r d il j a sẽkãt ã, dã lœ:r mezonet do est survenu cet orage. Alors, au premier coup de tonnerre, j'ai vu les pauvres bêtes redescendre et venir mourir sur leur litière ... Un désastre! Scholastique pleurait, j'avais envie d'en faire autant.

Monsieur Peyrolles, ému, puisa pour se donner courage une double prise dans sa tabatiòre en écaille qui grinça, et pendant quelques secondes, silencieusement, Madame Peyrolles, et lui s'entreregardèrent. Monsieur et Madame Peyrolles, ou - comme on les appelait plus communément dans le pays, en manière d'affectueuse familiarité - Monsieur Victrice et Madame Ambroisine étaient, dans toute la force du terme, des personnes de l'ancien temps. Bien portants quoique très âgés (leur mariage s'était fait alors que Charles dix régnait encore) ils vivaient de petites rentes, de ces toutes petites rentes qui autrefois suffisaient à constituer la fortune. Pauvres au fond, ils ne s'en apercevaient pas, ayant vieilli sans se créer aucun des besoins de la société nouvelle. Et ils étaient heureux, à la manière d'il $\mathrm{y}$ a cinquante ans, dans leur maisonette de 
la grã plas, u le mœblə fane $p \varnothing$ a $p \varnothing$, le glas lãtəmã terni gard $\varepsilon$ puir $\varnothing$, gras o suvəni:r, ynə me:m e im:uablə freSœ:r. sœlmã, a Sak rotuir $\mathrm{d}$ avril, madam ãbrwazin, dãz $\tilde{e}$ o gronje blã Si a la So e trãsforme ã mananəri, fozet yn õs u d $\varnothing$ də ve:r a swa ; e, kã la reysit ete bon, sla lœe:r permete do s ofri:r kellkə dusœ:r. 1 eləva:z de ve:r a swa $n \varepsilon$ pa kõsidere a kãtoperdri kom trava:j artizã, e la burzwazi atarde e apovri do so

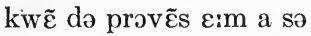
kree $\tilde{s}$, sã krwair deroze, œ modesto syplemã də rəvəny.

mez, elas! le ve:r a swa də madam äbrwazin $\mathrm{n}$ ave pa reysi set ane. sudẽ, la bon figy:r preokype də məsjø viktris s eklera.

— som nu be:t? e zo $\mathrm{n}$ i pãse sœlmã ply ! me zə p $\varnothing$ to 1 aSte, tõ Sa:l . . . notro rãt dy zas do bram-f $\tilde{\varepsilon}$, nu $\mathrm{n}$ 1 avõ zame tuSe dəpui 1 erita:3 dy povr õkl. vwala døz ane $d$ sla : a la Grand'Place, où les meubles fanés peu à peu, les glaces lentement ternies gardaient pour eux, grâce au souvenir, une même et immuable frâ̂cheur. Seulement, à chaque retour d'avril, Madame Ambroisine, dans un haut grenier blanchi à la chaux et transformé en magnanerie, faisait une once ou deux de vers à soie ; et, quand la réussite était bonne, cela leur permettait de s'offrir quelques douceurs. L'élevage des vers à soie n'est pas considéré à Canteperdrix comme travail artisan, et la bourgeoisie attardée et appauvrie de ce coin de province aime à se créer ainsi, sans croire déroger, un modeste supplément de revenu.

Mais, hélas ! les vers à soie de Madame Ambroisine n'avaient pas réussi cette année. Soudain, la bonne figure préoccupée de Monsieur Victrice s'éclaira.

- Sommes-nous bêtes? et je n'y pensais seulement plus! mais je peux te l'acheter, ton châle ... Notre rente du Jas de Brame-Faim, nous ne l'avons jamais touchée depuis l'héritage du pauvre oncle. Vorà deux années de cela : à 
sã sẽkãt frã par ã, lo total mõt a trwa sã

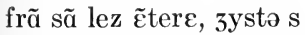

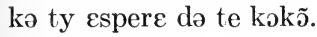
la dosy, məsjø e madam pero:l s egzalte:r : pøt õ s lese lãterne ह̃si? trwa sã frã, me s et yn som! e so fermje, so frederi, dõt il $\mathrm{n}$ ave zame sœlmãt apersy la figy:r! yn səme:n dyrã məsjø e madam perə:l nə parle:r.kə dy vwaja:3. kar sə n ete pa presizemã So:z komod kə d atẽdro lə dəme:n

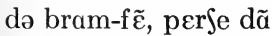
la mõtan, o dəsy dy vila:3 d ãtrəpje:r, luime:m deza perse o. katr œerr pu:r mõte, otã pu:r rədesãdr : yn absãs de tut ã zu:r. lə $\operatorname{dim} \tilde{\int} \int, \tilde{\text { o }}$ sə truva pre. yn vwazin ave prete sõn an, e lə bulãze sõ Sartõ u, sy:r d $\varnothing \int \varepsilon: z$ solidmãt amare, məsjø e madam pero:l s $\tilde{\varepsilon}-$ stale:r tã bjẽ kə mal, o milj $\phi$ do baga:zəz e provizjõ akumyle par skolastik.

- vuz ire drwa 3yska ãtropje:r, dize skolastik, ki konese lə pe:j ; cent cinquante francs par an, le total monte à trois cents francs sans les intérêts, juste ce que tu espérais de tes cocons.

Là-dessus, Monsieur et Madame Peyrolles s'exaltèrent : Peut-on se laisser lanterner ainsi? Trois cents francs, mais c'est une somme! Et ce fermier, ce Frédéri, dont ils n'avaient jamais seulement aperçu la figure! Une semaine durant Monsieur et Madame Peyrolles ne parlèrent que du voyage. Car ce n'était pas précisément chose commode que d'atteindre le domaine de Brame-Faim, perché dans la montagne, au-dessus du village d'Entrepierres, luimême déjà perché haut. Quatre heures pour monter, autant pour redescendre : une absence de tout un jour.

Le dimanche, on se trouva prêts. Une voisine avait prêté son âne, et le boulanger son charreton où, sur deux chaises solidement amarrées, Monsieu? et Madame Peyrolles s'installèrent tant bien que mal. au milieu des bagages et provisions accumulés par Scholastique.

- Vous irez droit jusqu'à Entrepierres, disait Scholastique, qui connaissait le pays ; 
a ãtropje:r, õ kit la

grãrut, me tu 1

mõd vuz ẽdikəra lo sãtje

$\mathrm{k}$ alor il fodra prãdr.

vu detelore a mimõte, pu:r dezøne, pre d ynə su:rs ki $\varepsilon$ suz $\tilde{e} \int \varepsilon$ :n. la vu lesre 1 Sartõ, parskə le vwaty:r nə võ pa ply lwẽ, e madam mõtəra sy:r 1 an. sore vu bate 1 an, o mw $\tilde{\varepsilon}$ ! 3 e atase lo ba a 1 arje:r də 1 ekipa:3. apre katrə bonz œrr də mõte, mwatje rulã, mwatje trotã, kõformemãt o program də skolastik, a trave:r buisõz e pjera:j, le vwajazœ:r $\tilde{a} f \tilde{\varepsilon}$ arive:r dəvã lo zas perdy do bram$\mathrm{f} \tilde{\varepsilon}$.

— sə n $\varepsilon$ pa bo ! di madam ãbrwazin, tirã sy:] lə bridõ pu:r kõsidere la mazy:r ruza:tr, ã kaju rule, avek sõ twa ba d u sortet $\tilde{\mathrm{e}} \mathrm{p} \emptyset$ də fyme. - le ble sõ kle:r, ropri mosjø viktris, 3 i vw dədã le grijõ kuri:r. e madam ãbrwazin kõkly :

— dàm! puir sã sãkãt frã par $\tilde{\alpha}, \tilde{\rho}$ nə $p \emptyset$ purtã paz avwa:r lo Sato dy marki də karaba. à Entrepierres, on quitte la grand'route, mais tout le monde vous indiquera le sentier qu'alors il faudra prendre. Vous détellerez à mi-montée, pour déjeuner, près d'une source qui est sous un chêne. Là vous laisserez le charreton, parce que les voitures ne vont pas plus loin, et madame montera sur l'âne. Saurezvous bâter l'âne, au moins ! J'ai attaché le bât à l'arrière de l'équipage.

Après quatre bonnes heures de montée, moitié roulant, inoitié trottant, conformément au programme de Scholastique, à travers buissons et pierrailes, les voyageurs enfin arrivèrent devant le Jas perdu de BrameTaim.

- Ce n'est pas beau! dit madame Ambroisine, tirant sur le bridon pour considérer la masure rougeâtre, en cailloux roulés, avec son toit bas d'où sortait un peu de fumée.

- Les blés sont clairs, reprit Monsieur Vic‘rice, j'y vois dedans les grillons courir.

Et Madame Ambroisine conclut :

- Dame! pour cent cinquante francs par an, on ne peut pourtant pas avoir le château du marquis de Carabas. 
məsjø viktris $\varepsilon d \tilde{a}$, madam ãbrwazin mi pjet a te:r, e tu le dø s avãse:r, suivi də 1 an. me sə $\mathrm{k}$ il vwaje, sə $\mathrm{ki} \mathrm{lez}$

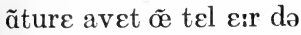
mize:r, k a 1 ide do dmãde d 1 arz $\tilde{a}$ il sə sãte deza 3ene.

- ty t eksplikra lə promje, viktris!

- il vodre pøte:tr mjø kə sə fy twa, äbrwazin ! a lœ:r aproઈ, dø galop $\tilde{\varepsilon}$ eburife ki $3 w \varepsilon$ d $\tilde{z} z \tilde{\mathrm{e}}$ ta de paij priar la fuit. lœ:r me:r, $\tilde{a} \operatorname{tr} \tilde{\varepsilon} d$ file sa kənuij syar œ̃ trõ d arbr, sa dresa.

— vu vuz e:t pe:rdy? . . vuz alje sã dut vizite pjesr ekrit? . . . alo:r, s $\varepsilon$ ply ba, pre do la surs, $\mathrm{k}$ il fale tuirne ...

viktris regarda ãbrwazin, ãbrwazin regarda viktris. pu:rtã lo kura:z lœerr mãka ; il lese:r krwa:r k il $\mathrm{s}$ ete perdy e $\mathrm{k}$ ilz ale vizite pjeir ekrit. la filø:z pary sulaze e di : - 3 avez y pœir dabor kə vu $\mathrm{n}$ fysje mosjø e madam perə:l, pars kə lə bj $\tilde{\varepsilon}$ et a $\varnothing$ e kə nu lœ:r dəvõ də 1 arzãa.
Monsieur Victrice aidant, Maduno Ambroisine mit pied à terre, et tous les deux s'avancèrent, suivis de l'âne. Mais ce qu'ils voyaient, ce qui les entourait avait un tel air de misère, qu'à l'idée de demander de l'argent ils se sentaient déjà gênés.

- Tu t'expliqueras le premier, Victrice!

- Il vaudrait peut-être mieux que ce fût toi, Ambroisine !

A leur approche, deux galopins ébouriffés qui jouaient dans un tas de paille prirent la fuite. Leur mère, en train de filer sa quenouille sur un tronc d'arbre, se dressa.

- Vous vous êtes perdus? ... Vous alliez sans doute visiter Pierre-Écrite? . . Alors, c'est plus bas, près de la source, qu'il fallait tourner ...

Victrice regarda Ambroisine, Ambroisine regarda Victrice. Pourtant le courage leur manqua ; ils laissèrent croire qu'ils s'étaient perdus et qu'ils allaient visiter Pierre-Écrite.

La fileuse parut soulagée et dit: - J'avais eu peur d'abord que vous ne fussiez Monsieur et Madame Peyrolles, parce que le bien est à eux et que nous leur devons de l'argent. 
puiz عl apla sõ mari : - ty pø tə mõtre, frederi, sə ne pa s $\varnothing$ kə nu krenjõ.

frederi desãdi dy gronje, suivi par lez ãfã dõ lez ¡ø timid luize. il ofrit o vizitœer dy $l \varepsilon$, il

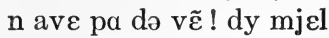
ã rejõ, de nwaz e de pom.

- s $\varepsilon$ tu s kə 1 o truv isi, la te:r $\varepsilon$ si po:vr! œrø:zmã kə le nuvo me:tr no nu trakas pa puir peje ; sã sla, ̃̃ $\mathrm{n}$ ore k a me:tr la kle su la po:rt. də bj $\tilde{\varepsilon}$ bən $3 \tilde{a}$ kə $\mathrm{nu} \mathrm{n}$ avõ zame vy. me vu dəve le kon$\varepsilon: t r$ si vuz $\varepsilon: t$ do la vil?

ãbrwazin e viktris dirr $\mathrm{k}$ ãn $\varepsilon f \varepsilon$ il koneset

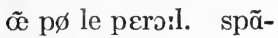
dã lə sole:j bese ; il fale prãdr yn desizjõ. — parl, dize madam ãbrwazin.

— nõ, parl, twa ! dize məs¡ø viktris.

il nə parle:r ni 1 o ni 1 otr.

bjẽ mjø, kã madam ãbrwazin rəmõta sy:r 1 an, alo:r la fam s aprofã :
Puis elle appela son mari : - Tu peux te montrer, Frédéri, ce n'est pas ceux que nous craignions.

Frédéri descendit du grenier, suivi par les enfants dont les yeux timides luisaient. Il offrit aux visiteurs du lait, il n'avait pas de vin! du miel en rayon, des noix et des pommes.

- C'est tout ce que l'on trouve ici, la terre est si pauvre! Heureusement que les nouveaux maîtres ne nous tracassent pas pour payer; sans cela, on n'aurait qu'à mettre la clef sous la porte. De bien bonnes gens que nous n'avons jamais vus. Mais vous devez les connaître si vous êtes de la ville?

Ambroisine et Victrice dirent qu'en effet ils connaissaient un peu les Peyrolles. Cependant le soleil baissait; il fallait prendre une décision.

- Parle, disait Madame Ambroisine.

- Non, parle, toi ! disait Monsieur Victrice.

Ils ne parlèrent ni l'un ni l'autre.

Bien mieux, quand Madame Ambroisine remonta sur l'âne, alors la femme s'approchant : 
- vu purje pøte:tro

vu Sarze d yn potit

kəmisjã, puiskə vu rəturnez a la vil. il s azire do porte sla do notro pa:r, a sə brav məsjø, a set brav madam pero:l.

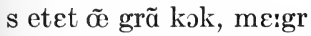
e sck, ki proteste, lje par lè pat.

õ lə syspãdit o $\operatorname{kr} \iint \varepsilon$ dy ba . . . e lo swa:r, kã le dø vjø fi:r löerr rãtre dã kãtəperdri, sy:r lə Sartõ, le $3 \tilde{a}$ dize dəvã le port, avek ynə nuãs d ãvi :

- vwala madam ãbrwazin e məsjø viktris ki s a rəvjent ã vwaty:r də tuje lœerr rãt do bramf $\tilde{\varepsilon}$ !

plezirr $d$ amuir

Ẽposiblo də rj $\tilde{\varepsilon}$ truve dã set abominablə mazy:r u nu rotone prizonje yno plyz abominabl ave:rs ; e nuz etjõ preskə rezine, domñ̃ e mwa, a murirr də

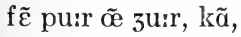
parmi le glusãto protestasjõ de trwaz u katro me:gro pul refyzje sy:r la metre:s puitro dy ãgar,
- Vous puurriez peut-être vous charger d'une petite commission, puisqua vous retournez à la ville. Il s'agirait de porter cela de notre part, à ce brave monsieur, à cette brave madame Peyrolles.

C'était un grand coq, maigre et sec, qui próestait, lié par les pattes.

On le suspendit au crochet du bât . . . Et le soir, quand les deux vieux firent leur rentrée dans Canteperdrix, sur le charreton, les gens disaient devant les portes, avec une nuance d'envie :

- Voilà Madame Ambroisine et Monsieur Victrice qui s'en reviennent en voiture de toucher leur rente de BrameFaim!

- Paul Arène.

\section{Plaisir d'amour}

Impossible de rien trouver dans cette abominable masure où nous retenait prisonniers une plus abominable averse; et nous étions presque résignés, Domnin et moi, à mourir de faim pour un jour, quand, parmi les gloussantes protestations de trois ou quatre maigres poules réfugicees sur la maîtresse poutre du hangar, 
nu vim ãselm rəpare:tr, syperb, le $\int \mathrm{v} \varnothing \mathrm{z}$ iradje də brẽ də pa:j, e tənãt o krø də se mẽz

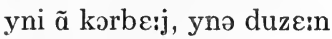
$\mathrm{d} \varnothing \mathrm{k}$ il ave deniङe. avek œ po d sidr a grã pen əptəny e lə restã də

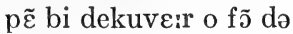
la u: $\int$, səsi nu promete, sinõ đ̃ rəpa kõfortablə, dy mw $\tilde{\varepsilon}$ də kwa satisfe:r noz apeti.

lo bœ:r, elas, fəzã defo, Ẽsi d ajœ:r kə lə lar e 1 uil, il fyc im:edjatmã deside kə 1 õ mãzəret a la kok se duz $\varnothing$ providãsjel.

$\mathrm{m} \varepsilon$, ki ale sə Sarze dy swẽ də le kuiir? 1 operasjõ $\varepsilon$ delikat ; tu dabor $z^{2}$

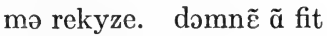
otã. kãt o brav ãsclm . . . ekute sə kə dit ãselm !

— dez ø a la kok? rjẽ də ply s̃̃pl ! e sã prezõpsjõ, 3 ə garãti də le reysi:r. sœlmã . . . - a ! il j a ̃̃e solmã. — wi! sœlmãt il mə fodret yn gita:r. set ãselm ete pozitivmã $\mathrm{fu}$ : yn gita:r puir kuiir $\operatorname{dez} \varnothing ? \quad \mathrm{k} \varepsilon \mathrm{l}$ asosjasjõ d ide sẽgulje:r. nous vîmes Anselme reparaître, superbe, les cheveux irradiés de brins de paille, et tenant au creux de ses mains unies en corbeille, une douzaine d'œufs qu'il avait dénichés.

Avec un pot de cidre à grand'peine obtenu et le restant de pain bis découvert au fond de la huche, ceci nous promettait, sinon un repas confortable, du moins de quor satisfaire nos appétits.

Le beurre, hélas, faisant défaut, ainsi d'ailleurs que le lard et l'huile, il fut immédiatement décidé que l'on mangerait à la coque ces douze œufs providentiels.

Mais, qui allait se charger du soin de les cuire? L'opération est délicate ; tout d'abord je me récusai. Domnin en fit autant. Quant au brave Amselme . . . écoutez ce que dit Anselme!

— Des œufs à la coque? Rien de plus simple! et sans présomption, je garantis de les réussir. Seulement ...

- Ah! il y a un seulement.

- Oui! seulement il me faudrait une guitare.

Cet Anselme était positivement fou : une guitare pour cuire des œufs? Quelle association d'idées singulière. 
dy rest, kom la $f \tilde{\varepsilon}$

prese e k okõ də nu

$\mathrm{n}$ ave də gita:r sy:r swa, $\tilde{\text { o }}$ pri la saz parti d kuirr lez $\varnothing$ o poti bonœ:r, ã le furã tu sẽpləmã dã do $l$ o bu:jãt. tã pi si, par mãk d eksperjãs, nu n obtənjã k dez $\varnothing$ dy:r, a la plas dez $\varnothing$ let $\varnothing \mathrm{z}$ e krem $\varnothing$ kə re:ve nətro guirmãdiz. e, pãdã kə lə fø s alyme, sa ki fy lõ, kar, œ bõ kar d œ:r dyrã, lə bwa veir e muije vomi de flo d epe:s fyme u nə brijet oky:n flam ; pãdã kə dã la lu:rdə marmit de fõt, 1 o fəze de fasõ pu:r bujirr, ãselm, plezãte amikalmã o syż də sez etrãzə prosede kylineir, y tu 1 tã d nuz eksplike kel rapo:r egziste, a sõ pw $\tilde{\varepsilon}$ də vy, ãtro la gita:r e la kuis̃̃ dez $\varnothing$.

— rije, supiret ãselm, rije! sa ki vu sãbla si komik eveij a mwa tut o kõtr£:r de suvəni:r plẽ d ẽtimə melãkəli. s et ẽsi : lez $\varnothing$ mə fõ sõze a la gita:r, la gita:r a kuzin ane:t ; e, romõtã la kurã de zu:r
Du reste, comme la faim pressait et qu'aucun de nous n'avait de guitare sur soi, on prit le sage parti de cuire les œufs au petit bonheur, en les fourrant tout simplement dans de l'eau bouillante. Tant pis si, par manque d'expérience, nous n'obtenions que des œufs durs, à la place des œufs laiteux et crémeux que rêvait notre gourmandise.

Et, pendant que le feu s'allumait, ce qui fut long, car, un bon quart d'heure durant, le bois vert et mouillé vomit des flots d'épaisse fumée où ne brillait aucune flamme; pendant que dans la lourde marmite de fonte, l'eau faisait des façons pour bouillir, Anselme, plaisanté amicalement au sujet de ses étranges procédés culinaires, eut tout, le temps de nous expliquer quel rapport existait, à son point de vue, entre la guitare et la cuisson des œufs.

- Riez, soupirait Anselme, riez! ce qui vous semble si comique éveille en moi tout au contraire des souvenirs pleins d'intime mélancolie. C'est ainsi : les œufs me font songer à la guitare, la guitare à cousine Annette; et, remontant le courant des jours 


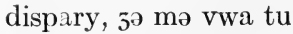
gamẽ dãz õ grã salõ · tãdy də pe:rs o kulœ:r kle:r, s uvrã do plẽpje sy:r $\tilde{e} z^{a r d} \tilde{\varepsilon}$ p $\emptyset$ kyltive ki fwazone d $\varepsilon$ :rbo fol, avek do o:to ro:z tremje:r o kalis deke:l mil bu:rdõ tuzu:r burdonã e parcijz a yn bãdə do patisjez ivro s ãfarine də polen d or. $\mathrm{s} \varepsilon$ la $\mathrm{k}$ abite kuzin anc:t. aze do pre də katrəvẽz $\tilde{\alpha}$, o fõ $\varepsilon l$ ete ma grã tãt ; me 3 1 apole kuzin ane:t, kom tu lə mõd, pars kãn $\varepsilon f \varepsilon$, Sak ane nuve:l, o ljø d la vjeji:r, lui aporte pu:r $\tilde{\varepsilon}$ si dirr $\tilde{œ}$ syrkrwa də gra:s ãfãtin. potit, d la ta:j k õ re:v o fe, sõ korsa:3 reste

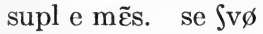
et $\varepsilon$ si f $\tilde{\varepsilon}$, avek do si vivã rofle $\mathrm{k}$ il par-

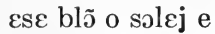
su le lymje:r. avek sla for koket do sõ pje miñ̃, ko volõtjez el

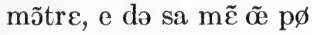
amegri u le bag do fam no tone ply, so ki 1 avet oblize, dopui kelko tĩ, a rəprãdro se bizu da zœen fi:j. disparus, je me vois tout gamin dans un grand salon tendu de perse aux couleurs claires, s'ouvrant de plainpied sur un jardin peu cultivé qui foisonnait d'herbes folles, avec de hautes roses trémières au calice desquelles mille bourdons toujours bourdonnants et pareils à une bande de pâtissiers ivres s'enfarinaient de pollen d'or.

C'est là qu'habitait cousine Annette. Agée de près de quatre-vingts ans, au fond elle était ma grand'tante ; mais je l'appelais cousine Annette, comme tout le monde, parce qu'en effet, chaque année nouvelle, au lieu de la vieillir, lui apportait pour ainsi dire un surcroît de grâce enfantine. Petite, de la taille qu'on rêve aux fées, son corsage restait souple et mince. Ses cheveux étaient si fins, avec de si vivants reflets qu'ils paraissaient blonds au soleil et sous les lumières. Avec celn fort coquette de son pied mignon, que volontiers elle montrait et de sa main un peu amaigrie où les bagues de femme ne tenaient plus, ce qui l'avait obligée, depuis quelque temps, à reprendre ses bijoux de jeune fille. 
də me:m, e par suit sã dut d ̃ misterjø rejonmã, tu parese 3œen otu:r do kuzin ane:t : lo fotœe:j orne də dø sf $\tilde{\varepsilon} \mathrm{ks}$, le $\int \varepsilon: z \tilde{a}$ form de lirr, la grãd kəməd e se kui:vrə, l etrãz mœbl a kolonet roprezãtã lə tãplo də vesta ki lui serve də tabl a uvra:3, e le vjø livrə k $\varepsilon l$ lize, e le vje:j

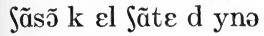
vwa fe:bl, me dusmã vibrãt. dã் la naivəte də mõ kœir d ãfã, 3 ว nurisez a 1 ãdrwa də kuzin anc:t œ̃ sãtimã mal defini, ply vwazẽ a ku sy:r do 1 amuir kə d 1 amitje. osi pu:r rjẽn o mõd, ni pu:r yñ benad d ekolje, 1 ete, o kurã kle:r də la rivje:r, ni purr yn ku:rs, l ive:r, lə lõ de ru:t sənə:rz e dy:r, kã la glas fœerjte ã vitr, krak su lo pje dã le fose, pu:r rjẽn o mõd 3 ə $\mathrm{n}$ :) re vuly mãke l ekstraordinع:r dezøne kə, Sakə $3 \varnothing \mathrm{di}, \mathrm{m}$ ofr $\varepsilon$ Sez el kuzin anc:t. dy pẽ fre, dy bœir e $\operatorname{dez} \varnothing \ldots \varnothing z$. . kski e kuiz ã myzik !
De même, et par suite sans doute d'un mystérieux rayonnement, tout paraissait jeune autour de cousine Annette : le fauteuil orné de deux sphinx, les chaises en forme de lyre, la grande commode et ses cuivres, l'étrange meuble à colonnettes représentant le temple de Vesta qui lui servait de table à ouvrage, et les vieux livres qu'elle lisait, et les vieilles chansons qu'elle chantait d'une voix faible, mais doucement vibrante. Dans la naïveté de mon cœur d'enfant, je nourissais à l'endroit de cousine Annette un sentiment mal défini, plus voisin à coup sûr de l'amour que de l'amitié.

Aussi pour rien au monde, ni pour une baignade d'écoliers, l'été, au courant clair de la rivière, ni pour une course, l'hiver, le long des routes sonores et dures, quand la glace feuilletée en vitres, craque sous le pied dans les fossés, pour rien au monde je n'aurais voulu manquer l'extraordinaire déjeuner que, chaque jeudi, m'offrait chez elle cousine Annette.

Du pain frais, du beurre et des œufs . . C Eufs exquis et cuits en musique! 
komã sla? vuz ale vwair.

il $\varepsilon$, kom Sakõe se, dif عrãt fasว̃ do kuiir lez $\varnothing$ a la kok. serte:n person prezõptyø:z ozə s ã fje a lœer sœl Ẽst ع. d o:tro kõt 3yska d $\varnothing$ sã, trwa sã. d o:troz ãko:r, pu:r məzyre le minyt, ãplwa lo sablje u bjẽ đ̃e kronome:tr myni d yn egui:j trotø:z. le devot e le sœ:r turje:r arivt o me:m rezylta, ãn egrənã de pater e dez ave. kuzin anc:t, d espri tuzurrz orizinal, avet imazine pu:r kui:r sez $\emptyset$ yn seremoni vremã ge, u 3 $3 \mathrm{w} \varepsilon$ mõ ro:l.

kuzin anc:t ton $\varepsilon$ sa gita:r. Ası sy:r õ tabure ba, mwa 3 ave, puir kõsin do toni:r lez $\varnothing$ pre e do syrveje la bu:jwar. — "kuzin ane:t, 1 o kəmãs a rïr !” . . . e, pẽsã leze:rəmã le kərd, kuzin ane:t prelyde. — "l o prã lo galo, kuzin anc:t !' . . . alo:r kuzin anc:t, lo rogar o sjel, la vwaz emy, kəmãse la naiv romãs do florjã :
Comment cela? Vous allez voir.

Il est, comme chacun sait, différentes façons de cuire les œufs à la coque. Certaines personnes présomptueuses osent s'en fier à leur seul instinct. D'autres comptent jusqu'à deux cents, trois cents. D'autres encore, pour mesurer les minutes, emploient le sablier ou bien un chronomètre muni d'une aiguille trotteuse. Les dévotes et les sœurs tourières arrivent au même résultat, en égrenant des Pater et des Ave. Cousine Annette, d'esprit toujours original, avait imaginé pour cuire ses œufs ıne cérémonie vraiment gaie, où je jouais mon rôle.

Cousine Annette tenait sa guitare. Assis sur un tabouret bas, moi j'avais, pour consigne de tenir les œufs prêts et de surveiller la bouilloire.

_ "Cousine Annette, l'eau commence à rire !" . . . Et, pinçant légèrement les cordes, cousine Annette préludait.

- "L'eau prend le galop, cousine Annette!" . . .

Alors cousine Annette, le regard au ciel, la voix émue, commençait la naïve romance de Florian: 
"plezi:r d amu:r nə dy:rə k $\tilde{e}$ momã,

"Sagrẽ d amu:r dy:ro tutə

la viว!

“§ e tu kite puir l ẼgraŁ̊ silvia.

"Elo mə kit e prãt õen o:tr amã."

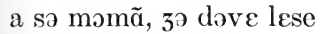
tõbe lez $\varnothing$ dã l o, e kuzin ane:t kõtinuet ã myltiplijã lez arpe:z :

"tã kə set o kurləra dusəmã

"ve:r lə ruiso ki bə:rdə la preria,

"zว t عməre, mo repete silviə.

"l o kul ãkø:r, el a Sãze purrtã."

la dəsy, $3^{\circ}$ rotire la bu:jwar ; kuzin ane:t roprəne avek ply do sãtimã e d a:m :

"plezi:r d amu-r no dy:ro k̃̃ momã,

"Sagrẽ d amu:r dy:rə tuto la viə!"”

e triõfaləmã, fəzã

ma parti o rəfr $\tilde{\varepsilon}$ sã

bjẽ kõprãdr — 3 e kõpri dəpui ! - sə kə set $\varepsilon: r$ dy tã pase evoke puir kuzin ane:t də re:vz e də du rəgre, 5 ãport $\varepsilon$
"Plaisir d'amour ne dure qu'un moment,

"Chagrin d'amour dure toute la vie!

"J'ai tout quitté pour l'ingrate Sylvie.

"Elle me quitte et prend un autre amant."

A ce moment, je devais laisser tomber les œufs dans l'eau, et cousine Annette continuait en multipliant les arpèges :

"Tant que cette eau coulera doucement

"Vers le ruisseau qui borde la prairie,

"Je t'aimerai, me répétait Sylvie.

"L'eau coule encore, elle a changé pourtant."

Là-dessus, je retirais la bouilloire ; cousine Annette reprenait avec plus de sentiment et d'âme :

"Plaisir d'amour ne dure qu'un moment,

"Chagrin d'amour dure toute la vie!"

Et triomphalement, faisant ma partie au refrain sans bien comprendre - j'ai compris depuis! - ce que cet air du temps passé évoquait pour cousine Annette de rêves et de doux regrets, j'emportais 
lez $\emptyset$ kui a pwẽ, dõ nu nu regaljõz ã te:t a te:t dã də delisjø kəktje u sə vwaje, or sy:r fõ blø, de kuron də mirt, de buke do ro:z, de kolõb sə bektã, dez amu:r $3 w \tilde{a}$ dy tãburẽ, de ly:t, de myzets e de fly:t. о 3 u:r, - kuzin anc:t, so matẽ-la, plyz atõdri $\mathrm{k}$ a sõn abity:d, m ave mõtre, dõ le tirwa:r də sa kəməd, tu:t sortə də suvəni:r, œ buke desefe, de letro lje də favœ:r, avek lə portre $\mathrm{d} \tilde{\mathrm{e}}$ bel əfisje ã kostym də ysa:r ru:z, 一 $\tilde{e}$ zuir, fəzã kuir noz $\varnothing$, il mə pary kə kuzin anc:t ralãtise par tro la məzy:r, e zə sõzєz a par mwa : lez $\emptyset$ sã du:t sərõ dy:r se swa:r. lez $\varnothing \mathrm{n}$ et $\varepsilon \mathrm{pa}$ dy:r, mez il sə truve:r mole.

— зə n i kõprã rj $\tilde{\varepsilon}$, dize kuzin ane:t, vwala bjẽ la promje:r fwa kə "plezi:r d amu:r" mә zu so tuir-la . . . e, surjã tuzu:r, me lezesromãt atriste : "p $\varnothing t \varepsilon: t r \tilde{e} p \varnothing$ d emosjã? e pui il fo krwa:r k õ sə $f \varepsilon$ vje:j ! les œufs cuits à point, dont nous nous régalions en tête à tête dans de délicieux coquetiers où se voyaient, or sur fond bleu, áes couronnes de myrte, des bouquets da roses, des colombes se becquetant, des amours jouant du tambourin, des luths, des musettes et des fûtes.

Un jour, - cousine Annette, ce matin-là, plus attendrie qu'à son habitude, m'avait montré, dans les tiroirs de sa commode, toutes sortes de souvenirs, un bouquet desséché, des lettres liées de faveurs, avec le portrait d'un bel officier en costume de hussard rouge, - un jour, faisant cuire nos œufs, il me parut que cousine Annette ralentissait par trop la mesure, et je songeais à part moi : les œufs sans doute seront durs ce soir. Les œufs n'étaient pas durs, mais ils se trouvèrent mollets.

- Je n'y comprends rien, disait cousine Annette, voilà bien la première fois que "Plaisir d'amour" me joue ce tour-là . . . Et, souriant toujours, mais légèrement attristée : "Peut-être un peu d'émotion? et puis il faut croire qu'on se fait vieille! 
s $\varepsilon$ lə lãdəmع də sə zu:r

ke kuzin ane:t mury.

lə bõ djø də Səmije

ki n $\varepsilon$ ni pu:r ni kõtr

lezãdə də turع:n

lo kyre do Səmije s ãn

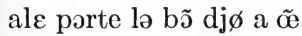
malad.

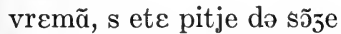

kə kelkõe puve murir

par œ si bo zu:r d ete, a

plen ãzelys də midi, lə

momã do la vi e do la

lymje:r.

s etع pitje osi do sõze

ka sə po:vro kyre avet ete əblize də sə me:tr ã ru:t

tu də suit ã sortã də

tabl, a 1 œ̃:r u d abity:d

il ale - lo brevje:r o

$\mathrm{m} \tilde{\varepsilon}-\mathrm{f} \varepsilon: \mathrm{r} \tilde{\varepsilon}$ bu də

sjest su sa potit tone:l do

vin, o fre e o rəpo

d œ̃ 3 əli $3 \operatorname{ard} \tilde{\varepsilon}$ plẽ də

pe:S my:r e də ro:z

tremje:r.

"senœir, zə vu l ofr,"

pãse lə sẽt om ã

supirã, e mõte sy:r đ̃n

a:nə gri avek sõ bã djø

dəvã lui ã trave:r dy ba,

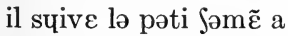

miko:t ãtro la roS ru:3
C'est le lendemain de ce jour que cousine Annette mourut.

- PaUl ArÈne.

\section{Le bon Dieu de Chemillé}

qui n'est ni pour ni contre

Légende de Touraine

Le curé de Chemillé s'en allait porter le Bon Dieu à un malade.

Vraiment c'était pitié de songer que quelqu'un pouvait mourir par un si beau jour d'été, en plein Angelus de midi, le moment de la vie et de la lumière.

C'était pitié aussi de songer que ce pauvre curé avait été obligé de se mettre en route tout de suite en sortant de table, à l'heure où d'habitude il allait-le bréviaire aux mains - faire un bout de sieste sous sa petite tonnelle de vigne, au frais et au repos d'un joli jardin plein de pêches mûres et de roses trémières.

"Seigneur, je vous l'offre," pensait le saint homme en soupirant, et monté sur un âne gris avec son Bon Dieu devant lui en travers du bât, il suivait le petit chemin à mi-côte entre la roche rouge 
tut pike də mu:səz $\tilde{\mathrm{a}}$ flœ:r, e la pãto də ka:ju e də o:tə brusa:j ki degrẽgole zysko preri. 1 a:n parcjmã, lə po:vr a:n, supire "senœ:r, $3 \ni$ vu $l$ ofr," e il lə supiret a sa manje:r, ã ləvã tãtot yn ore:j, tãto l o:tr, puir Sase le mu:S ki lə turmãte.

$\mathrm{s} \varepsilon \mathrm{k} \varepsilon \mathrm{l}$ sõ meSãt e burdonãt, le mus də midi ; avek sla, la ko:t a mõte, e lə kyre də Səmije, ki pəze si lurr, syrtut ã sortã də tabl ! də tãz ã tã de peizã pase syr lə $\int m \tilde{\varepsilon}$ e sə

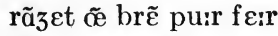
plas o bõ djø, avek sə ku də Sapo partikylje de peizã də ture:n ; 1 œ:j malẽ e lə saly respekty $\varnothing$, lə roga:r ki a 1 e:r də s moke dy 3 est. a Sakõ məsjø lo kyre rãde sõ saly pu:r lə kõt dy bõ djø, tre polimã, me sã bjẽ savwa:r

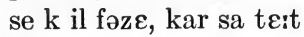
komãset a sə rãpli:r do some:j.

lə tãz ete So, la ru:t blãS. o ba dy koto, derje:r le pœplije, le pti flo d la lwa:r resãblet toute piquée de mousses en fleurs, et la pente de cailloux et de hautes broussailles qui dégringolait jusqu'aux prairies. L'âne pareillement, le pauvre âne, soupirait "Seigneur, je vous l'offre," et il le soupirait à sa manière, en levant tantôt une oreille, tantôt l'autre, pour chasser les mouches qui le tourmentaient.

C'est qu'elles sont méchantes et bourdonnantes, les mouches de midi ; avec cela, la côte à monter, et le curé de Chemillé, qui pesait si lourd, surtout en sortant de table! De temps en temps des paysans passaient sur le chemin et se rangeaient un brin pour faire place au Bon Dieu, avec ce coup de chapeau particulier des paysans de Touraine ; l'œil malin et le salut respectueux, le regard qui a l'air de se moquer du geste. A chacun Monsieur le curé rendait son salut pour le compte du Bon Dieu, très poliment, mais sans bien savoir ce qu'il faisait, car sa tête commençait à se remplir de sommeil.

Le temps était chaud, la route blanche. Au bas du coteau, derrière les peupliers, les petits flots de la Loire ressemblaient 
a dez ekaij d arz̃̃ ebluisãt. tu:t set lymje:r repãdy, se bu:rdõnmã d abe:j ki sulove de pusje:r do flo:r syr la ru:t, $\jmath_{\partial} \int \tilde{a}$ de griv dã le vi:n, œ̃ $\int \tilde{a} œ r \varnothing$ də pətit be:t gurmã:d e rasazje, a ¡ove d asupi:r lo kyre; tut eturdi deza par œ bõ dezøne də v $\tilde{\varepsilon}$ blã e de rije:t. vwala kə, pase vilãdri, la u la roS dəvjẽ ply o:t e lə redijõ plyz etrwa, lo kyre də Səmije fy tire vivəmã də sõ səme:j par le "dja! y !’ d $\tilde{e}$ Sartje ki s ã vənet ã fas də lui, avek œе grã Sarjo də fw $\tilde{\varepsilon}$ balãse lu:rdəmã a Sak tu:r də ru.

lə məmã et $\varepsilon$ kritik. me:m ã sə se:rã lə ply posi:blə kõtrə la roS, il $\mathrm{n}$ j ave pa plas pu:r d $\varnothing$ dã lə $\int \mathrm{m} \tilde{\varepsilon}$. . . rədesãdrə 3ysk a la grã ru:t? lo kyre nə lo puve pa, ejã pri sa sãtje pu:r ale ply vit e saSã sõ malad a tut ekstremite. $\mathrm{s} \varepsilon \mathrm{s} \mathrm{k}$ il eseja d eksplike o Sartje ; $m \varepsilon$ lə rystrə nə vule rjẽn ãtãdr. " $3 \tilde{a}$ sui faSe, məsjø à des écailles d'argent éblouissantes. Toute cette Iumière répandue, ces bourdonnements $\mathrm{d}$ abeilles qui soulevaient des poussières de fleurs sur la route, le chant des grives dans les vignes, un chant heureux de petite bête gourmande et rassasiée, achevaient d'assoupir le curé, tout étourdi déjà par un bon déjeuner de vin blanc et de rillettes. Voilà que, passé Villandry, là où la roche devient plus haute et le raidillon plus étroit, le curé de Chemillé fut tiré vivement de son sommeil par les "dia! hue !" d'un charretier qui s'en venait en face de lui, avec un grand chariot de foin balancé lourdement à chaque tour de roue.

Le moment était critique. Même en se serrant le plus possible contre la roche, il n'y avait pas place pour deux dans le chemin ... Redescendre jusqu'à la grand'route? Le curé ne le pouvait pas, ayant pris ce sentier pour aller plus vite et sachant son malade à toute extrémité. C'est ce qu'll essaya d'expliquer au charretier; mais le rustre ne voulait rien entendre.

"J'en suis fâché, Monsieur 
l kyre, dit il sã rotire sa pip ; me la zurne $\varepsilon$ tro So:d puir kə zə $\mathrm{m} \tilde{a}$ rətu:rn ve:r aze par lo detu:r. bã pu:r vu, ki vuz ãn ale bjẽ trãkilmã sy:r votr $a: n$. . . - me, malœrø, ty $\mathrm{n}$ a dõk pa vy sa ka 3 e la. $\mathrm{s} \varepsilon$ lə b̃̃ djø, məve kretjẽ, lə bõ djø də Səmije, kə zə pərt a $\tilde{e}$ malad.

— zə sui də vilãdri, rikana

lə Sartje. lo bõ djø də Səmije nə mə rəga:rdə pa ... d dja! y!" e lo pajẽ alõza đ̃ ku d fwe a sõn atola:3 pu:r lo fє:r avãse, o riskə . d ãvwaje l a:n e tu s $\mathrm{k}$ il $\mathrm{j}$ ave dosy rule o ba dy koto, dã 1 patyra:3.

notrə kyre n ete pasjã kə tu 3yst. " $a ! \mathrm{s} \varepsilon$ kom

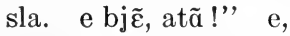
sotãt a ba də sa be:t, il poza bjẽ delikatmã lə bõ djø

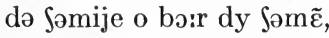
sy:r yn tuf da serpole, parmi le zəne d or e lo liknis blã, vre nap d otel flœri e parfyme, kom õ $\mathrm{n}$ a truv pa me:m a la katedral do

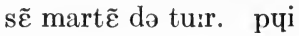

le curé, dit-il sans retirer sa pipe ; mais la journée est trop chaude pour que je m'en retourne vers Azay par le détour. Bon pour vous, qui vous en allez bien tranquillement sur votre âne . . .

- Mais, malheureux, tu n'as donc pas vu ce que j'ai là. C'est le Bon Dieu, mauvais chrétien, le Bon Dieu de Chemillé, que je porte à un malade.

- Je suis de Villandry, ricana le charretier. Le Bon Dieu de Chemillé ne me regarde pas ... Dia! hue!" et le païen allongea un coup de fouet à son attelage pour le faire avancer, au risque d'envoyer l'âne et tout ce qu'il y avait dessus rouler au bas du coteau, dans le pâturage.

Notre curé n'était patient que tout juste. "Ah! c'est comme cela. Eh bien, attends!" Et, sautant à bas de sa bête, il posa bien délicatement le Bon Dieu de Chemillé au bord du chemin. sur une touffe de serpolet, parmi les genêts d'or et les lychnis blancs, vraie nappe d'autel fleurie et parfumée, comme on n'en trouve pas même à la cathédrale de Saint-Martin de Tours. Puis 
lə sẽt om s azənuja e fi setə ku:rtə prije:r : "bõ djø də Səmije, ty vwa so ki $m$ ariv e kə sə mekreã va m oblize do lo metr a la

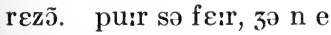

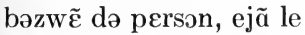
pwaje tre solid e lə bõ drwa da mõ kote . . . resta dõ la bjẽ trãkil, a roga:rde notro bata:j, e no swa ni pu:r ni kõtr. sõn af $\varepsilon: r$ səra vit regle." sa prije:r dit, il sə rələva e kəmãsa pa:r rotruse se mãj, sə ki fi vwa:r apre se $m \tilde{\varepsilon}$, se be:l mẽ də kyre du:səz e poli pa:r le benediksjõ, d $\varnothing$ pwaje də bulãze, solid kom de n $\emptyset$ də fre:n . . . vli ! vlã ! dy prəmje ku, lo Sartje y sa pip kase ãtr le dã. dy səgõ, il sə truva kuðe o fõ dy fose, õt $\varnothing$, muly, im:obil. apre kwa lo kyre fi rokyle la Saret, la rãza bjẽ swanøzmã o lõ du taly, la te:t dy Sval dã l õbr d ̃̃ myrje, e $\mathrm{s}$ ãn ala o poti tro ve:r sõ malad, k il truva asi dã $s \varepsilon$ rido d $\tilde{\varepsilon}$ djen, rəmi d sa fje:vrə kom par mirakl e $\tilde{a} \operatorname{tr} \tilde{\varepsilon}$ de debuSe õ vjø flakõ do le saint homme s'agenouilla et fit cette courte prière : "Bon Dieu de Chemillé, tu vois ce qui m'arrive et que ce mécréant va m'obliger de le mettre à la raison. Pour ce faire, je n'ai besoin de personne, ayant les poignets très solides et le bon droit de mon côté . . Reste donc là bien tranquille, à regarder notre bataille, et ne sois ni pour ni contre. Son affaire sera vite réglée."

Sa prière dite, il se releva et commença par retrousser ses manches, ce qui fit voir après ses mains, ses belles mains de curé douces et polies par les bénédictions, deux poignets de boulanger, solides comme des nœuds de frêne ...

Vli! vlan! Du premier coup, le charretier eut sa pipe cassée entre les dents. Du second, il se trouva couché au fond du fossé, honteux, moulu, immobile. Après quoi le curé fit reculer la charrette, la rangea bien soigneusement au long du talus, la tête du cheval dans l'ombre d'un mûrier, et s'en alla au petit trot vers son malade, qu'il trouva assis dans ses rideaux d'indienne, remis de sa fièvre comme par miracle et en train de déboucher un vieux flacon de 
vuvre mus $\varnothing$, pu:r bj $\tilde{\varepsilon}$

sə rəprãdr a la vi. $3^{\partial}$ vu le:s a pãse si notro kyre

1 عda dã son operasjõ. dəpчi sə tã la, lə b̃̃ djø də Səmije $\varepsilon$ tre popyle:r ã ture:n, e s $\varepsilon$ lụi kə le turãzoz $\tilde{\varepsilon}-$ vok dã tu:t lœir dispy:t : "b̃̃ djø də Səmije, nə swa ni pu:r ni kõtr . . ." se lə vre djø de bata:j, sə djø də Səmije ki nə $\mathrm{f} \varepsilon$ də favœ:r a person e le:s Sakõ triõfe səlõ sa fo:rs e sõ bõ drwa.

la tart a la kre:m

fre: $\int$ e blõd, œ̃ 3ãti

$$
\text { babi, }
$$

e, pur mõn a:3, ase

savãt,

3ə mə rãgərzว kãt ว̃ vãt

me ui prẽtã pase

d avri.

me ma gu:rmãdiz et

ekstre:m :

3adis, 3 o 1 avu ãtro nu, 3ə mə metez a d $\varnothing$ zonu dəvãt ynə tart a la krع:m.

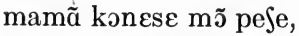
osi, kã zavez ete sa:z, $\varepsilon l$ a ate syr sõ pasa:3 mẽtə friãdiz o marße.
Vouvray mousseux, pour bien

- se reprendre à la vie. Je vous laisse à penser si notre curé l'aida dans son opération.

Depuis ce temps-là, le Bon Dieu de Chemillé est très populaire en Touraine, et c'est lui que les Tourangeaux invoquent dans toutes leur disputes: "Bon Dieu de Chemillé, ne sois ni pour ni contre ..." C'est le vrai Dieu des batailles, ce Dieu de Chemillé qui ne fait de faveurs à personne et laisse chacun triompher selon sa force et son bon droit.

- PaUl ArÈne.

\section{La tarte à la crème}

Fraîche et blonde, un gentil babil,

Et, pour mon âge, assez savante,

Je me rengorge quand on vante Mes huit printemps passés d'avril.

Mais ma gourmandise est extrême :

Jadis, je l'avoue entre nous, Je me mettais à deux genoux Devant une tarte à la crème.

Maman connaissait mon péché, Aussi, quand j'avais été sage, Elle achetait sur son passage Mainte friandise au marché. 
e s etet õ bonœerr sypre:m, $\tilde{\propto}$ Sarm $\tilde{\varepsilon}$ disibl e prof $\tilde{\jmath}$ kã, dã sõ panje, tut o f $\tilde{\text {, }}$

3ə vwaje ma tairt a la kre:m.

me satã mə gete, satã vule terni:r mon a:mə blã :

"la tart, el $\varepsilon$ la, syr la plãs.",

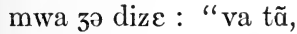
va tã."

le demõ, ply fo:r kə mwa me:m,

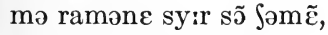
gidã me pa, pusã ma $\mathrm{m} \tilde{\varepsilon}$,

e . . $3^{\partial}$ pri la tart a la kre:m.

kã mamã pary tut a $\mathrm{ku}$, 3 avez ynə frejœ:r mortel : "se bõ, la tartə, mə ditel, mez yno, sə n $\varepsilon$ pa bo$\mathrm{ku}$.

pu:r kõtãte 1 ãfã kə

3 E:m, minənə, 3 ə v $\varnothing$ Sakə swa:r, a la plas u ty va $t$ aswa:r,

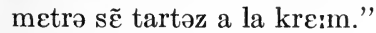

s atãdr o kuru sã mersi

d ynə mamã ki grõd e ton,
Et c'était un bonheur suprême, Un charme indicible et profond Quand, dans son panier, tout au fond,

Je voyais ma tarte à la crème.

Mais Satan me guettait, Satan Voulait ternir mon âme blanche :

_ "La tarte, elle est là, sur la planche."

Moi je disais : "Va-t-en, va-t-en.'

Le démon, plus fort que moimême,

Me ramenait sur son chemin, Guidant mes pas, poussant ma main,

Et ... je pris la tarte à la crème.

Quand maman parut tout à coup,

J'avais une frayeur mortelle :

"C'est bon, la tarte, me ditelle,

Mais une, ce n'est pas beaucoup.

Pour contenter l'enfant que j'aime,

Mignonne, je veux chaque soir, A la place où tu vas t'asseoir, Mettre cinq tartes à la crème."

S'attendre au courroux sans merci

D'une maman qui gronde et tonne, , 
e s ãtãdro dirr : "o, minon!"

$\mathrm{n} \tilde{\mathrm{o}}, \mathrm{m \varepsilon}$ vu vwaje sa

$\mathrm{d}$ isi.

30 kryz a kelkə strataze:m, 3 ale supe lo kœer navre. o! stypœ:r! mamã dize vre :

3 ave š̃ tartəz a la kre:m.

de tarto grãdə . . .

kəmə sa :

pw $\tilde{\varepsilon}$ nə fy bəzw $\tilde{\varepsilon}$ də mə

batr, $3^{\tilde{a}}$ mãze d $\varnothing$, pui trwa,

pui katr.

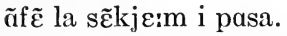
me s $\varepsilon$ bjẽ dro:lə tu də

me:m, mə di 3 , ã mə metãt o li,

3ə sui priz ã flagrã deli, e ze de tartoz a la kre:m !

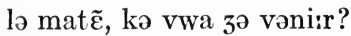
o:tro tartə kə $z^{\jmath}$ devo:r, lo tãto, lo swa:r, tart ã-

korr . . . me . . sa nə va dõ ply

fini:r . .

$\mathrm{s}$ et $\varepsilon$ trãblãt $\mathrm{e}$ lo frõ

ble:m

kə 3 apreãde lə rəpa :

— "ñ̃, mamã, ñ̃, зə n a v $\varnothing$ pa."

— "mãzə setə tart a la kre:m."
Et s'entendre dire: "O, Mignonne I"

Non, mais vous voyez ça d'ici.

Je crus à quelque stratagème, J'allai souper le cœur navré.

Oh! stupeur! maman disait vrai :

J'avais cinq tartes à la crème.

Des tartes grandes... comme ça :

Point ne fut besoin de me battre,

J'en mangeai deux, puis trois, puis quatre.

Enfin la cinquième y passa.

Mais c'est bien drôle tout de même,

Me dis-je, en me mettant au lit,

Je suis prise en flagrant délit, Et j'ai des tartes à la crème !

Le matin, que vois je venir? Autres tartes que je dévore, Le tantôt, le soir, tarte encore . .

Mais... ça ne va donc plus finir ...

C'était tremblante et le front blème

Que j'appréhendais le repas :

_ "Non, maman, non, je n'en veux pas."

_ "Mange cette tarte à la crème." 
e səla dyra yi grã $\mathfrak{j}^{u: r}$. avek ynə frejœ:r teribl, 3 apersove la kre:m ori:bl

a 1 ekol, o $3 \varnothing$, su me dra.

il fale la mãze kã me:m.

— "mamã, tu sə kə ty vudra, tu, me ply do tart a la kre:m.';

mamã pardon : el a suri ; pw $\tilde{\varepsilon}$ n

diz, dy gro peSe də gu:rmãdiz mõ kœir et a $3^{a m \varepsilon}$ geri. mõ djø! vu vudrije

$\mathrm{k} \tilde{a} \mathrm{~m} \varepsilon: \mathrm{m}$, e si me ve:r vu sãblo b̃̃, $\mathrm{m}$ ofrir $\mathrm{d} \varnothing \ldots$. trwa . . katrə bôbõ . . . $o$ ! me! pa də tart a la kre:m.
Et cela dura huit grands jours. Avec une frayeur terrible, J'apercevais la crème horrible

A l'école, au jeu, sous mes draps.

Il fallait la manger quand mème.

- "Maman, tout ce que tu voudras,

Tout, mais plus de tarte à la crème."

Maman pardonne: elle a souri; Point n'est besoin que je le dise,

Du gros péché de gourmandise Mon cœur est à jamais guéri.

Mon Dieu! vous voudriez quand même,

Et si mes vers vous semblent bons,

M'offrir deux ... trois . quatre bonbons ...

Oh! mais! pas de tarte à la crème.

- Auguste Clément.

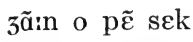

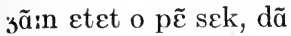

lo kabine nwa:r, pur œ krimə kelkõk e mãkãt o dəvwa:r,

\section{Jeanne au pain sec ${ }^{1}$}

Jeanne était au pain sec, dans le cabinet noir,

Pour un crime quelconque et, manquant au devoir,

${ }^{1}$ The phonetic value of memorizing good poetry cannot be overestimated. It is suggested that each pupil learn some poem and practice till he can recite it perfectly. 
3 ale vwa:r la kupabl $\tilde{\alpha}$

ple:nə forfety:r,

e lưi glise, dã 1 õbr,

œ̃ po də kõfity:r

kõtre:r o lwa. tu sø

sy:r ki, dã ma site, rəpo:zə lə saly də la sosijete s Ẽdinz:rət, e zãan a di d yno vwa du:s :

" 3 ว nə tuऽəre ply mõ ne avek mõ pu:s,

" 3 ə nə mə fəre ply grife par

lə mine."

mez õ se rekrije : "set

ãfã vu kone,

"عlə set a kel pwẽ vuz

e:tə fe:bl e la:S,

"Ela vu vwa tuzuir rirro,

kãt ว̃ sə fa: . ..."

e ze di : "zə n e rjẽn a

repõdr a sala,

ze torr e set avek sez

Ẽdylzãsə la

kõn a tuzu:r kõdụi le

pœplaz a lœ:r pe:rt :

kõ mə met o p $\tilde{\varepsilon}$

sek."

— " "̃ vuz i metra, se:rt,

vu lə merite." 3 a:n,

alo:r, dã sõ kwẽ nwa:r,

m a di, ləvã sy:r mwa sez

jø si boz a vwa:r,

plẽ də l otərite de duisa

kreaty:r :

— "e bjẽ , mwa, zə t ire

porte de kõfity:r."
J'allai voir la coupable en pleine forfaiture,

Et lui glissai, dans l'ombre, un pot de confiture

Contraire aux lois. Tous ceux sur qui, dans ma cité,

Repose le salut de la société

S'indignèrent, et Jeanne a dit d'une voix douce :

"Je ne toucherai plus mon nez avec mon pouce,

"Je ne me ferai plus griffer par le minet."

Mais on s'est récrié : "Cette enfant vous connaît,

"Elle sait à quel point vous êtes faible et lâche,

Elle vous voit toujours rire, quand on se fâche ..."

Et j ai dit: "Je n'ai rien à répondre à cela,

J'ai tort et c'est avec ces indulgences-là

Qu'on a toujours conduit les peuples à leur perte :

Qu'on me mette au pain sec."

- "On vous y mettra, certes, Vous le méritez." Jeanne, alors, dans son coin noir, M'a dit, levant sur moi ses yeux si beaux à voir,

Pleins de l'autorité des douces créatures :

- "Eh bien, moi, je t'irai porter des confitures."

- Victor Hugo. 


\section{libe:rte}

də kel drwa mete vu lez

wazo dã le ka:3?

də kel drwa ote vu se

Sãtœerrz o boka:3,

o su:rsəz, a 1 oro:r, a la

nye, o vã?

də kel drwa vole vu la vi

a se vivã? ...

kâ vu kadənase suz

๓̃ rezo də $\mathrm{f} \varepsilon$ :r

tu se byvœ:r d azy:r $f \varepsilon$

purr $s$ ãnivre $d \varepsilon: r$, tu se nazœ:r Sarmã də

la lymje:rə blø,

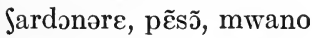

frã, əЈək $\emptyset$,

nə kə̃prəne vu pa kə

vuz $\varepsilon$ :tə me ã ?

a tu sez ãferme, done la

kle de $\int \tilde{a}$ !

o Sã le rosinol,

o Sã lez irõd $\varepsilon: 1$ !

lez a:məs ekspjərõ tu sə

k õ fet oz $\varepsilon: l$. . .

la balõs $\tilde{\varepsilon}$ vizibl a d $\varnothing$

platoz opsky:r : prone gard o kaSo do

vuz orne vo my:r! dy treja:3 o fil d or

ne:sə le nwa:rə gri:j ;

la volje:ro $\operatorname{sinistr} \varepsilon$ me:rə

de basti:j ;

respe o du pasã dez

$\varepsilon: r$, de pre, dez o !

\section{Liberté}

De quel droit mettez-vous les oiseaux dans les cages?

De quel droit ôtez-vous ces chanteurs aux bocages,

Aux sources, à l'aurore, à la nuée, aux vents?

De quel droit volez-vous la vie à ces vivants? . . .

Quand vous cadenassez sous un réseau de fer

Tous ces buveurs d'azur faits pour s'enivrer d'air,

Tous ces nágeurs charmants de la lumière bleue,

Chardonneret, pinson, moineau franc, hochequeue,

Ne comprenez-vous pas que vous êtes méchants?

A tous ces enfermés, donnez la clef des champs!

Aux champs les rossignols, aux champs les hirondelles!

Les âmes expieront tout ce qu'on fait aux ailes . . .

La balance invisible a deux plateaux obscurs :

Prenez garde aux cachots dont vous ornez vos murs!

Du treillage aux fils d'or naissent les noires grilles ;

La volière sinistre est mère des bastilles ;

Respect aux doux passants des airs, des prés, des eaux! 
tu:tə la libe:rte k õ prãt a dez wazo, lo dest $\tilde{\varepsilon}$ zyst e dy:r la rəprãt a dez om. nuz avõ de tirã parsə - kə nuz ã som.
Toute la liberté qu'on prend à des oiseaux, Le destin juste et dur la reprend à des hommes.

Nous avons des tyrans parce que nous en sommes.

Victor Hugo: Legende des siècles. 
VOCABULARY 



\section{VOCABULARY OF PHONETIC TRANSCRIPTION}

à, to, at, in, into, on, of, from, with; out (or not to be translated); à cause de, because of ; à carreaux, check; il visa le merle à l'aile gauche, he took aim at the blackbird's left wing; vers à soie, silkworms; à bas, down; à jamais, forever; reste donc là tranquille à regarder notre bataille, stop there quiet and look at our fight.

abeille, $f$., bee.

abominable, abominable.

abonner, (to) put down one's name as a subscriber ; s'abonner, (to) subscribe.

abord, m., access, approach ; d'abord, at first, first of all ; tout d'abord, first and foremost.

absence, $f$., absence.

accomplir, (to) fulfill, realize.

accorder, (to) grant.

accrocher, (to) hang up, hook. accumuler, (to) heap up, accumulate.

accuser, (to) accuse.

acheter, (to) buy ; achetez-vous donc, go and buy. achever, (to) finish, end ; achevaient d'assoupir le curé, made the priest finally quite drowsy.

adosser, (to) lean against; adossé, leaning against.

adresser, (to) address.

affaire, $f$., business, concern.

affectueu-x, -se, affectionate.

âge, $m$., age.

âgé-e, old; âgée de près de 80

ans, being nearly 80 years old. s'agenouiller, (to) kneel down. agir, (to) do, act; il s'agirait

de, we want you to.

agrément, $m$., pleasure.

aider, (to) help ; Monsieur Victrice aidant, with Monsieur Victrice's help.

aiguille, $f$., needle, hand (of a watch or clock); aiguille trotteuse, second-hand (of a watch). aile, $f$., wing.

ailleurs, elsewhere ; d'ailleurs, besides, moreover.

aimer, (to) like, love, be fond of. ainsi, thus, in this way; ainsi que, as well as; pour ainsi dire, so to say; ainsi soit-il! amen! so be it! 
air, m., air, tune; avait un tel air de misère, looked so miserable; avoir l'air de, (to) seem to.

ait, pres. subj. of avoir; jusqu'à ce qu'elle ait les joues plus rouges que son chapeau, until her cheeks were redder than her hood.

aligner, (to) set in a row.

aller, (to) go; s'en aller, (to) go off, leave; s'en allèrent went off; s'en allait, was going off; tu vas t'en aller, you must go and; aller voir, (to) go and see; d'aller faire un tour, of going for a turn; qui est allé, who went; vous allez voir, you will see.

allonger, (to) deal (a blow).

allumer, (to) light; s'allumer,

(to) take or catch fire, be lighted.

alors, then, so ; alors que, when. amaigri, grown thin, emaciated. amant, $m$., lover.

amarrer, (to) moor, make fast. âme, $f$., soul, heart.

ami-e, $m$. and $f$., friend.

amicalement, in a friendly way. amitié, $f$., friendship.

amour, $m$., love, Cupid.

an, $m$., year.

ancien-ne, old; des personnes

de l'ancien temps, old-

fashioned people.

âne, $m$., donkey.
Angélus, m., Angelus.

année, $f$., year.

apercevaient, imp. ind. of aper-

cevoir.

apercevais, imp. ind. of apercevoir.

apercevoir, (to) perceive, no-

tice; s'apercevoir de, (to) notice.

aperçu, p. p. of apercevoir. aperçut, pret. of apercevoir. appauvrir, (to) impoverish. appeler, (to) call; on les appelait, they were called; s'appelait, was called. appétit, m., appetite. apporter, (to) bring. appréhender, (to) dread, fear. approche, $f$., approach. s'approcher, (to) come up. après, after.

arboriculture, f., arboriculture (cultivation of trees).

arbre, $m$., tree.

archet, $m$. , bow. argent, $m$., money, silver. arpège, $m$., arpeggio. arracher, (to) tear off. arrêter, (to) stop, arrest. arrière, m., stern, back. arriver, (to) arrive, happen. artisan, m., artisan, mechanic, workman; n'est pas considéré à Canteperdrix comme travail artisan, is considered more of an art than a craft at Canteperdrix. 
as, pres. ind. of avoir.

aspect, $m$., aspect, sight, view; un vieux petit homme d'aspect misérable, a miserablelooking, little old man.

asseoir, (to) seat; s'asseoir,

(to) sit down; où tu vas t'asseoir, where you sit. assez, enough, rather, fairly. assis-e, p. p. of asseoir, seated, sitting down, sitting up. assit, pret. of asseoir; elle s'assit, she sat down. association, $f$., association. assoupir, (to) make drowsy. assurer, (to) assure ; s'assurer,

(to) make sure of, secure. attacher, (to) fasten, tie (up). attarder, (to) delay, retard; attardé, behind the times; la bourgeoisie attardée et appauvrie de ce coin de province, the impoverished middle classes in this secluded country-place who were rather behind the times. atteindre, (to) reach, hit, strike, wound.

atteint, $p$. $p$. of atteindre. attelage, $m$., team.

attendre, (to) wait (for) ; s'attendre à, (to) expect; sans attendre, without waiting. attendri, tender. attrister, (to) sadden. au, to the, in the, at the, at; au lit, in bed; au moment où just when; Jeanne au pain 'see, Jane put, ôn' dry bread.

aucun-ie, adj;, any, nu

aucun-e, pron., not one, nore; aucun ne, not one, none. auprès (de), near, close to. aurais, cond. of avoir (translated had after lorsque). aurait, cond. of avoir. auras, fut. of avoir. aurore, $f$., dawn. aussi, such, so, too, and so ; un danseur aussi leste, such a nimble dancer.

aussitôt, immediately, at once. autant, as much; de faire autant, (to) do the same thing.

autel, m., altar.

autour (de), round.

autorité, $f$., authority.

autre, other; autre chose, something else, anything else; ne .. . autre chose, nothing else; d'autres, others.

autrefois, formerly.

aux, to the (his, its), for the, at the, on the, in the (his, its); de la taille qu'on rêve aux fées, the size one dreams fairies to be of.

avais, imp. ind. of avoir; j'avais envie de, I felt inclined to; j'avais une frayeur mortelle, I was in a mortal fright; moi 
j'avais pour consigne, my instructions were.

avait, imp. ind. of avoir; il y avaiit, theré "wasis'; Jeàn arait 'ber "cectir, Jean was kindhearted; avait un tel air de misère, looked so miserable. avance, $f$., advance, start ; en avance $\mathrm{de}$, in advance, beforehand.

avancer, (to) go on; s'avancer, (to) go forward.

avant, before; avant peu, in a short time; avant que, before.

avare, $m$. , miser.

avare, adj., miserly.

Ave M., Latin Catholic prayer.

avec, with, by; avec un bruit

de trompette, as loud as a trumpet; avec gaîté, gayly; avec Scholastique, I and Scholastique; avec cela, added to that.

averse, $f$., shower (of rain). avez, pres. ind. of avoir. avoir, (to) have; avoir l'air,

(to) seem; de lui avoir volé sa bourse, of having robbed him of his purse; après l'avoir déchiré, after having torn him; pour l'avoir faussement accusé, for having falsely accused him. avouer, (to) confess. avril, m., April. ayant, pres. part. of avoir. ayez, imperative and subj. of avoir.

azur, $m$., azure.

babil, $m$., babble, prattle.

bagage, m. (generally used in the plural in French), luggage. bague, $f$., ring.

baignade, $f$., dip, bath.

baisser, (to) go down.

balance, f., scales (for weighing).

balancer, (to) swing or move to and fro.

bande, $f$., troop, gang.

bas, $m$., bottom.

bas-se, low; plus bas. lower

down; à bas, down.

bastille, $f$., fortress-prison.

bât, $m$., pack-saddle.

bataille, $f$., battle, fight.

bâter, (to) saddle.

bâton, $m$., stick.

battre, (to) beat.

bavardage, $m$., chatter.

beau (bel), belle, fine, beautiful, handsome.

beaucoup, (very) much.

becqueter, (to) pick; se bec-

queter, (to) bill and coo.

bel, see beau.

belle, see beau.

bénédiction, $f$., blessing, benediction, benison.

besogne, $f$., work.

besoin, $m$., need; avoir besoin de, (to) need. 
bestiole, $f$., creature, beastie. bête, $f$., animal, creature, mount. bête, adj., silly, stupid.

beurre, $m$., butter.

bien, $m$., property, estate. bien, $a d v$., well, very, quite, very well, quite well; si bien que, so that; il faut bien mourir, people MUST die (this word is very much used in French to give greater emphasis to the accompanying word. It is often better in English not to translate it, but simply to emphasize the accompanying word; for instance, il faut bien mourir, people Must die; mon valet est bien forcé de rester chez moi, my man is obLigED to stay with me); eh bien! well! bien portante, in good health; pour bien se reprendre à la vie, to make another good start in life; bien mieux, better still; ou bien, or else.

bientôt, soon.

bijou, $m$., jewel ; bijoux, jewelry. biquet, $m$. , kid.

bis, brown.

blanc-he, white.

blanchir, (to) whiten; blanchi à la chaux, whitewashed.

blé, $m$., corn; les blês, the corn. blême, pale; le front blême, with a pale face. bleu, blue.

blond-e, fair.

bobinette, $f$., string.

bocage, $m$., grove.

bohémien-ne, gypsy, gypsy-

man, gypsy-woman.

boire, (to) drink.

bois, m., wood.

bon, bon-ne, good, kind, nice;

le bon dieu, God, the Host, the Holy Sacrament; bon pour vous ! it's all very well for you! bonne femme, dame; la réussite était bonne, they were a great success.

bonbon, $m$., sweet, candy.

bondir, (to) bound, caper.

bonheur, m., happiness; au petit bonheur, as well as we could.

bonne, see bon.

bonnet, $m$., cap.

bonté, $f$., kindness, goodness.

bord, $m$., edge.

border, (to) skirt.

bouillir, (to) boil.

bouilloire, $f$., kettle.

boulanger, $m$., baker ; poignets

de boulanger, baker's wrists. bouquet, $m$., bunch (of flowers). bourdon, $m$., drone, humblebee, bumble-bee.

bourdonnement, $m$., buzzing. bourdonner, (to) hum, buzz. bourgeoisie, $f$., middle classes. bourgeon, $m$., bud, shoot ; bour- 
geon à bois, branch-shoot; bourgeon à fruit, fruit-shoot. bourre, $f$, bud, shoot. bourreau, $m$., executioner. bourse, $f$., purse. bout, $m$., end; faire un bout de sieste, (to) take a little nap. bouton, $m$., button.

bras, m., arm.

brave, brave, good, honest.

bréviaire, $m$., breviary.

bridon, $m$., small bridle.

briller, (to) shine.

brin, $m$., blade (of grass), bit.

brindille, $f$., twig.

broussailles, $f$. $p l$., brushwood. bruit, m., noise; du bruit, a

noise; avec un bruit de trompette, as loud as a trumpet.

brûler, (to) burn.

brusquement, suddenly, hastily. bruyère, $f$., heather, broom. buisson, $m$., bush.

but, $m$., mark.

buveur, m., drinker.

ça, that, it.

cabanette, $f$., breeding-cage. cabinet, $m$., small room; dans le cabinet noir, in the dark. cachot, $m$., dungeon. cadenasser, (to) padlock. cage, $f$., cage.

caillou, $m$., pebble, stone ; cailloux roulés, shingle of round stones. calice, $m$., calyx.

canon, $m$., gun, cannon. capuchon, $m$., hood.

car, for.

Carabas, the Marquis de Carabas is a well-known character in the French fairy tale of Puss in Boots (Le chat botté).

carreau, m., tile; à carreaux, check.

carrefour, m., cross-roads.

carriole, $f$., small cart with a hood.

cas, m., case; en tout cas, at all events.

casser, (to) break.

cathédrale, $f$., cathedral.

cause, $f$., cause; à cause de, because of.

ce, adj., this, that, the; ce . . -ci, this; ce . . -là, that. ce, pron., this, that. it (sometimes not to be translated, sometimes translated by a personal or demonstrative pronoun, he, she, they, these, those, etc.) ; ce qui, ce que, what, which (sometimes not translated); jusqu'à ce que, until; c'est pour mieux te voir, all the better to see you with; c'est pour mieux te serrer, all the better to hug you with; c'est pour mieux t'entendre, all the better to hear you with; 
c'est pour te croquer, they chanter, (to) sing.

are to eat you with; tout chanteur, $m$., singer.

ce que, all that; c'est que, chapeau, m., hat; coup de that is because (or often chapeau, bow.

not translated); c'est bon la chaperon, m., hood; le petit tarte, the tart is nice.

ceci, this, it.

cela, that, it; voilà deux années

de cela, that's two years ago. celui, $\dot{m}$., the one.

cependant, meanwhile.

cercle, $m$., club.

cérémonie, $f$., ceremony.

cerise, $f$., cherry ; son joli capu-

chon couleur de cerise, her pretty cherry-colored hood.

certain-e, certain.

certes, certainly.

cesser (de), (to) stop.

cet, adj., m., this, that.

cette, adj., $f$., this, that.

ceux, those, these, the ones, the people.

chacun-e, every one, each one. chagrin, $m$., sorrow, grief.

chaise, $f$., chair.

châle, $m$., shawl.

champ, m., field; donnez la clef des champs, give their liberty; aux champs les rossignols, aux champs les hirondelles, to the fields with the nightingales, to the fields with the swallows.

changer, (to) change.

chanson, $f$., song.

chant, $m$., song, singing.

Chaperon Rouge, little Red Riding Hood.

chaque, each, every.

chardonneret, $m$., goldfinch.

charger, (to) load; se charger,

(to) undertake, take upon oneself; se charger d'une commission, (to) take a message, take something.

chariot, $m$., wagon.

charitable, charitable.

Charles Dix, brother of Louis

XVI; he was king of France 1824-1830.

charme, $m$., charm.

charmant-e, charming.

charretier, $m$., carter, wagoner.

charreton, $m$., little cart.

charrette, $f$., cart.

chasser, (to) drive away.

château, $m$., castle, hall, country

seat, mansion.

chaud-e, warm.

chaux, f., lime; blanchi à la chaux, whitewashed.

Chemillé, a small city in Touraine in the center of France. chemin, m., way, track, path, road; me ramenait sur son chemin, brought me back towards it; en chemin, on the way. 
chêne, $m$., oak.

cher, chère, dear.

chercher, (to) look for; envoyer chercher, (to) send for. cherra, future of choir.

cheval, $m$., horse.

cheveux, m. pl. (generally used

in plural in French), hair.

chevillette, $f$., pin, latch.

chèvre, $f$., goat.

chez, to, with ; chez ma mère-

grand, to my grandmother's;

chez elle, at her house.

chien, m., dog.

choir, (to) fall.

choisir, (to) choose.

chose, $f$., thing; autre chose, something else, anything else; ne .. autre chose, nothing else.

chou, m., cabbage.

chrêtien, m., Christian.

chronomètre, $m$., chronometer.

cidre, $m$., cider.

ciel, m., sky, heaven; le regard au ciel, looking up to the sky (heaven).

cité, $f$., city.

clair-e, clear, bright, limpid;

les blés sont clairs, the corn is thin; aux couleurs claires, bright-colored.

clef, $f$., key ; mettre la clef sur la porte, (to) run away (without paying one's debts); donnez la clef des champs, give their liberty. clou, $m$., nail.

cocon, m., cocoon.

cœur, m., heart.

coin, $m$., corner ; coin de province, secluded country place. colombe, $f$., dove.

colonnette, $f$., small column. combien, how much, how many. comique, comic, laughable. commander (à), (to) command. comme, as, like, as of ; comme on n'en trouve pas, such as you do not find; comme vous avez de grands yeux, what big eyes you have; comme vous avez de gros bras, what big arms you have; comme vous avez de grandes oreilles, what big ears you have; comme vous avez de longues dents, what long teeth you have; ah ! c'est comme cela, ah! that's how it is; de nuit comme de jour, night as well as day. commencer, (to) begin.

comment, how; il sut comment faire, he knew what to do, he knew how to manage; comment cela? how was that?

commission, f., message; se charger d'une commission, (to) take a message, take something.

commode, easy.

commode, $f$., chest of drawers, bureau. 
communément, commonly. compatissant-e, compassionate. compliment, m., compliment; recevez mes compliments, I congratulate you.

comprendre, (to) understand ; sans comprendre, without understanding.

compris-e, $p$. p. of comprendre. compte, m., account, score; pour le compte de, on account of.

compter, (to) count.

conclure, (to) conclude.

conclut, pres. and pret. of con-

clure.

condamner, (to) sentence.

conduire, (to) take, lead.

conduisait, imperfect of con-

duire.

conduit, p. p. of conduire.

conférence, $f$., lecture.

confitures, $f$. $p l$., jam.

conformément (à), according to. confortable, comfortable.

connaissaient, imperfect of con-

naître.

connaissait, imperfect of connaître.

connaît, pres. ind. of connaître. connaître, (to) know.

connût, subjunctive of connaître. considérer, (to) consider, sur-

vey.

consigne, f., instructions

(plural).

constituer, (to) constitute. conte, $m$., tale; contes de fées, fairy tales.

content-e, happy.

contenter, (to) please, satisfy ;

se contenter (de), (to) con-

tent oneself (with).

contester. (to) dispute.

continuer, (to) go on.

contraire, m., contrary; con-

traire aux lois, unlawfully.

contre, against.

convaincre, (to) convict.

convainquit, pret. of convaincre. coq, m., cock.

coque, $f$., shell, egg shell ; œufs

à la coque, boiled eggs.

coquet-te, vain.

coquetier, $m$., egg-cup.

corbeille, $f$., basket; au creux

de ses mains unies en cor-

beille, in the hollow depths

of his linked hands.

corde, f., string, tether, rope.

corsage, $m$., bodice.

costume, m., costume, dress.

côte, f., hill; à mi-côte, half-

way up the hill.

coteau, m., hill, slope.

cou, m., neck; le loup prit ses

jambes à son cou, the wolf took to his heels.

coucher, (to) lie; se coucher,

(to) lie down; couché, lying in bed.

couler, (to) flow; tant que cette eau coulera, as long as this water flows. 
couleur, $f$., color; son joli capuchon couleur de cerise, her pretty cherry-colored hood; aux couleurs claires, bright-colored.

coup, m., tug, stroke, hit, clap; coup de fouet, lash; tout à coup, all of a sudden, suddenly ; à coup sûr, to a certainty, certainly; coup de chapeau, bow.

coupable, $m$. and $f$., guilty

person.

couper, (to) cut.

courage, $m$., courage.

courant, m., current, course; remontant le courant des jours disparus, going back over past times.

courir, (to) run (about).

couronne, $f$., wreath.

courroux, m., wrath.

course, $f$., race.

court-e, short.

cousin-e, $m$. and $f$., cousin. craignions, imperfect of craindre.

craindre, (to) be afraid of, fear.

craquer, (to) crack. créer, (to) create; se créer,

(to) make for oneself.

crème, $f$., cream, custard. crèmeu-x, -se, creamy. creux, $m$., hollow.

crier, (to) cry.

crime, $m$., crime. critique, adj., critical; le moment était critique, the moment was a critical one. crochet, $m$., hook. croire (à), (to) think, believe (in); sans croire déroger, without considering that they are lowering themselves; ils laissèrent croire, they let it be thought; il faut croire, I suppose.

croquer, (to) eat.

crus, pret. of croire.

crut, pret. of croire; qui crut à

une accalmie, who thought the storm had subsided.

cueillir, (to) pick, gather.

cuire, (to) cook; de cuire, of cooking; faisant cuire, cooking.

cuisson, $f$., cooking. cuit, $p$. $p$. of cuire.

cuivre, $m$., brass, copper.

culinaire, culinary.

cultiver, (to) cultivate.

curé, m., parish priest.

d'ailleurs, besides, moreover.

dame, interj., well! why!

dangereu-x, -se, dangerous. dans, in, into, out of ; puiser . . dans, to take ... out of ; dans la misère, destitute; toujours dans tes histoires et tes méthodes, etc., always fussing about your methods, etc. 
danse, $f$., dance ; tous entraient en danse, all joined the dance. danser, (to) dance; pour danser, for dancing. danseur, $m$., dancer. de, of, from, to, out of, in, on, for, with, by, any (after a negative); (de should often not be translated); d'abord, (at) first; de plus, besides, else ; de 1', de la, some, any ; d'assez méchante humeur, in rather a nasty temper; bijoux de jeune fille, jewelry she had as a girl; de même, in the same way.

déboucher, (to) uncork, draw the cork (of).

déchirer, (to) tear. décider, (to) decide. décision, $f$., decision. découvert, $p$. $p$. of découvrir. découvrir, (to) discover. dedans, in (it). défaut, $m$. , fault; le beurre hélas ! faisant défaut, there being alas! a lack of butter. définir, (to) define; mal défini, ill-defined. degré, $m$., step. dégringoler, (to) tumble down; qui dégringolait, falling down. déjà, already.

déjeuner, (to) have lunch.

déjeuner, $m$., lunch.

délicat-e, delicate. délicatement, delicately. délicieu-x, - se, delicious.

délit, m., misdemeanor, delinquency; en flagrant délit, in the very act.

demain, to-morrow.

demande, $f$., request.

demander, (to) ask (for); de demander, asking for.

demeurer, (to) live.

démon, m., demon, fiend.

dénicher, (to) hunt out, ferret out.

dénoncer, (to) denounce.

dent, $f$., tooth.

dépouiller, (to) strip, deprive; on l'avait dépouillé, he had been stripped.

depuis, since; depuis que, since; depuis quelque temps, some time before, for some time.

derni-er, -ère, last.

déroger, (to) derogate; sans croire déroger, without considering that they are lowering themselves.

derrière, behind; pattes de derrière, hind legs.

désastre, $m$., disaster.

descendre, (to) go down, come down.

desquelles, of which.

dessécher, (to) dry, wither.

dessus, $a d v$., on it; là-dessus, thereupon; au-dessus de, above.

destin, m., fate. 
dételer, (to) take out the dise, subj. of dire; point n'est horse(s).

détour, turn, bend, way round. deux, two; tous les deux, both (of them).

devais, imperfect of devoir; je devais, it was my business to. devant, in front of, opposite, before; renâcler devant, (to) grumble at.

devenir, (to) become, get. devenu, $p$. $p$. of devenir; sont devenus, became. devez, pres. ind. of devoir, must.

devient, pres. ind. of devenir. devoir, (to) be obliged (to), have to, owe.

devoir, m., duty.

devons, pres. ind. of devoir.

dévorer, (to) devour.

dévote, $f$., pious woman. devra, fut. of devoir, will have to.

diable, m., devil.

dieu, m., God; le bon Dieu, God, the Host, the Holy Sacrament.

différent-e, different. dimanche, $m$., Sunday. dire, (to) tell, say; ce que je veux dire, what I mean. disais, imperfect of dire. disait, imperfect of dire. disant, pres. part. of dire; en disant ces mots, as he said these words.

besoin que je le dise, there is no need for me to say so. discussion, $f$., quarrel. disparaître, (to) disappear. disparu, $p$. p. of disparaitre; les jours disparus, past times. disparut, pret. of disparaitre. dispute, $f$., dispute, contest, squabble.

dit, pres. ind. of dire.

dit, pret. of dire.

dit, $p . p$. of dire; sa prière dite, when his prayer was said. doigt, $m$., finger ; j'en ai encore les doigts picotés, the pricks are still on my fingers from it. doléance, $f$., grievance.

domaine, $m$., domain, property, state.

don, $m$., gift.

donc, so; achetez-vous donc, go and buy; laisse donc les arbres tranquilles, do leave the trees alone.

donner, (to) give.

dont, of which, with which, whose, on which; dont il se moucha, with which he blew his nose; dont il se servit encore, which he used again ; dont ils n'avaient jamais seulement aperçu la figure, whose face they had never even seen.

dormir, (to) sleep.

double, double. 
doucement, gently, softly. douceur, $f$., creature-comfort, luxury.

douleur, $f$., pain.

doute, m., doubt; sans doute, probably, doubtless.

douter, (to) doubt; se douter,

(to) suspect.

doux, douce, sweet, soft, gentle. douzaine, $f$., dozen.

drap, $m$., sheet.

dresser, (to) straighten; se dresser, (to) stand (straight) up.

droit, m., right; le bon droit, the right.

droit, adv.; straight.

droite, $f$., right; à droite, to or on the right.

drôle, funny.

$\mathrm{du}$, of, some (often not to be translated); du premier coup, at the first hit; du second, at the second; du bruit, a noise.

duquel, rel. pron., m. s., of which; auprès duquel, near which.

dur-e, hard, hard-boiled.

durant, during, for; une semaine durant, for a whole week.

durer, (to) last.

eau, $f$., water.

éblouissant-e, dazzling.

éborgner, (to) put out (a per- son's) eye; éborgner des arbres, (to) cut off the superfluous buds or shoots. ébouriffé, in disorder; deux galopins ébouriffés, two shock-headed urchins. écaille, $f$., tortoise shell, scale. échelle, $f$., ladder.

échelon, $m$., rung.

éclairer, (to) light up ; s'éclairer, (to) light up.

éclore, (to) be hatched, hatch, open.

école, $f$., school.

écolier, m., school boy, scholar;

une baignade d'écoliers, a bath with the boys.

écorcher, (to) flay, fleece; tu as suffisamment écorché le pauvre monde que les épines te le rendent, you have fleeced the poor long enough, now the thorns shall fleece you.

écouter, (to) listen (to).

écraser, (to) crush; on s'écrasait les pieds, they trod on each other's feet.

s'écrier, (to) cry (out); la voix de son ancien maître s'écrier, his old master's voice crying. écu, $m$., crown.

effet, m., effect; en effet, in fact.

égratigner, (to) scratch.

égrener, (to) tell (one's beads) ; en égrenant des Pater et des 
Ave, by reciting Paters and Aves.

eh, interj.; eh bien, well, very well then! eh quoi! what then!

élevage, $m$., breeding. elle, she, her; pour elle, for her sake.

embrasser, (to) kiss, embrace, hug.

emotion, $f$., emotion. empêcher, (to) prevent. employer, (to) use. emporter, ( $t$ ') carry off. ému, p. p. of émouvoir, touched; la voix émue, in a feeling voice. en, adv. and pron., of it, it (often not translated); tu vas t'en aller . . ., you must go and . . . ; il en fut de même, the same thing happened; je saurai bien m'en passer, I can quite well do without them; j'en ai encore les doigts picotés, the pricks are still on $\mathrm{my}$ fingers from it, nous avons des tyrans parce ( ue nous en sommes, we have tyrants because we are tyrants.

en, prep., to, at, by, into, on, made of (sometimes not to be translated); en chemin, on the way; en même temps, at the same time; en tout cas, at all events ; en manière de, by way of. encore, again, yet, still (sometimes not translated); encore un petit air, one more little tune; tarte encore, another tart.

endroit, m., place, spot; à l'endroit de, with respect to. enfant, $m$. and $f$., child ; d'enfant, childish. enfantin-e, childish, girlish. enfariner, (to) beflour, sprinkle with flour; s'enfariner de, (to) beflour oneself with. enfermer, (to) shut up; ces enfermés, these prisoners. enfin, at length, at last. enivrer, (to) intoxicate; s'enivrer, (to) become intoxicated. ennuyer, (to) annoy, bore. ensuite, then.

entendre, (to) hear, listen to; on entendait du bruit, a noise was heard; qui force à danser tous ceux qui l'entendent, which will force anybody who hears it to dance; et s'entendre dire, and to hear some one say to you.

entourer, (to) surround. entrain, $m$., spirits, high spirits ; plus il y mettait d'entrain, the more vigorously he did it. entre, between.

s'entre-choquer, (to) knock against each other, come into collision. 
entrer, (to) go in (to); qui est entré dans Biquette, that went into Biquette; tous entraient en danse, all joined the dance.

s'entre-regarder, (to) look at one another.

entrevoir, (to) perceive, catch sight of.

entrevoyait, imperfect of entrevoir.

envie, f., envy; avoir envie de, (to) feel inclined to.

envoyer, (to) send; envoyer chercher, (to) send for.

épais-se, thick.

épine, $f$., thorn.

équipage, $m$., carriage, cart.

es, pres. ind. of être.

espalier, $m$., wall fruit tree.

espérer, (to) hope (for).

esprit, $m$., disposition, turn of

mind; simple d'esprit, simple minded.

essayer, (to) try.

est, pres. ind. of être, is (some-

times translated was); est à, belongs to; il est, there are. et, and.

étagère, $f$., shelves $(p l$.$) .$

était, imperfect of être, was.

étaient, imperfect of être, were

(with reflexive verbs translate had).

étant, pres. part. of être. été, $m$., summer ; un jour d'été, a summer day. été, $p . p$. of être.

éteindre, (to) put out.

êtes, pres. ind. of être.

étions, imperfect of être.

étourdir, (to) stun; tout étourdi

déjà par un bon déjeuner, dizzy as he already was after

a good lunch.

étrange, strange.

être, (to) be.

étroit-e, narrow.

eut, pret. of avoir.

eût, imperfect subjunctive of

avoir, had, would have; pour qu'elle eût le temps, for her to have the time; sans attendre que le vert eût poussé aux mûriers, without waiting for the green to have come out on the mulberry trees. eux, them.

eux-mêmes, themselves; les chiens eux-mêmes, the very dogs.

éveiller, (to) awake, rouse.

évoquer, (to) call up, evoke.

s'exalter, (to) become very excited.

excellent-e, excellent.

exister, (to) exist.

expérience, $f$., experience.

expier, (to) atone for, expiate.

expliquer, (to) explain; s'ex-

pliquer, (to) explain matters. exquis-e, exquisite.

exterminer, (to) exterminate; voilà pourtant deux mois que 
nous nous exterminions, yet we had been wearing ourselves out for two months. extraordinaire, extraordinary. extrême, excessive, extreme. extrémité, $f$., extremity; toute extrémité, dying.

face, $f$., front; qui s'en venait en face de lui, who was coming towards him.

fâché, sorry.

fâcher, (to) make angry; se fâcher, (to) be or get angry. façon, $f$., way; l'eau faisait des façons pour bouillir, the water made difficulties about boiling.

faible, weak, feeble.

faim, $f$., hunger.

faire, (to) do, manage, make; se faire, (to) become, get; faire une faveur, (to) grant a favor; faire un bout de sieste, (to) take a little nap; faire part de quelque chose à quelqu'un, (to) acquaint somebody with something; d'aller faire un tour, of going for a turn; faire une conférence, (to) give a lecture; faire place à, (to) make room for.

fais, pres. ind. and imperative of faire.

faisait, imperfect of faire; l'eau faisait des façons pour bouillir, the water made difficulties about boiling.

faisant, pres. part. of faire; le beurre hélas ! faisant défaut, there being alas! a lack of butter; faisant ma partie, singing my part; faisant cuire, cooking.

fait, pres. ind. of faire.

fait, $p$. $p$. of faire; réflexion faite, all things considered; ayant fait quelques pas, having gone a few steps; leur mariage s'était fait, their marriage had taken place.

fallait, imperfect of falloir; il fallait la manger; I had to eat it, it had to be eaten; il fallait tourner, you should have turned; il fallait prendre une décision, a decision had to be made.

falloir, (to) be necessary, have to.

fallu, $p . p$. of falloir; depuis qu'il a fallu s'abonner, since we have had to subscribe; il nous a fallu, we had (to). fameu-x, -se, famous.

familiarité, $f$., familiarity.

faner, (to) fade; les meubles fanés peu à peu, the furniture which had faded little by little.

faudra, future of falloir; qu'alors il faudra prendre, which you must take then. 
faudrait, cond. of falloir; il me faudrait une guitare, I must have a guitar.

faussement, falsely.

faut, pres. ind. of falloir; il faut bien mourir, people must die; que me faut-il de plus, what else do I need; il faut croire, I suppose.

fauteuil, $m$., armchair.

faveur, $f$., bit of ribbon; faire des faveurs, (to) grant favors. fée, $f$., fairy; contes de fées fairy tales.

femme, $f$., wife, (married) woman.

fer, $m$., iron.

ferai, future of faire; je ne me ferai plus griffer par le minet, I won't let the cat scratch me again.

fermier, $m$., farmer.

feu, $m$., fire.

feuille, $f$., leaf.

feuilleté-e: la glace feuilletée en vitres, the thin layers of ice.

fidèlement, faithfully.

fier, (to) trust, confide in ; s'en fier à, (to) trust to, rely on, depend on.

fièvre, $f$., fever.

figure, $f$., face.

fil. m., thread.

filer, (to) spin; en train de filer, who was spinning. fileuse, $f$., spinner. fille, f., girl.

fin-e, fine

fin, $f$., end

finir, (to) finish; ça ne va donc plus finir, will they never be done.

firent, pret. of faire.

fit, pret. of faire, did, made, said; même il n'en fit qu'une bouchée, he even swallowed her at a single mouthful; se fit rendre la sarbacane, got back the peashooter; fit voir, showed; fit reculer, moved back.

flacon, $m$., bottle.

flagrant-e, flagrant; en flagrant délit, in the very act.

flamme, $f$., flame.

fleur, $f$., flower; en fleur, in flower, flowering.

fleuri-e, decked with flowers.

Florian, French writer of the eighteenth century.

flot, m., flood, torrent, wave, billow.

flûte, $f$., flute.

foi, $f$, faith.

foin, $m$., hay.

foire, $f$, fair.

fois, $f$., time ; une fois, once.

foisonner, (to) swarm; qui foisonnait d'herbes folles, which had abundance of weeds.

fond, m., bottom, background, ground; pauvres au fond, 
although they were in the main poor.

fonte, $f$., cast-iron, iron.

force, $f$., force, power, strength ;

dans toute la force du terme des personnes de l'ancien temps, thoroughly old-fashioned people.

forcer, (to) force, oblige; qui force à danser tous ceux qui l'entendent, which will force anybody who hears it to dance.

forfaiture, $f$., forfeiture ; en pleine forfaiture, in the very midst of her crime.

forme, $f$., shape.

former, (to) form, frame.

fort, $a d v$., very.

fort-e, adj., strong.

fort, $m$., fort.

fortune, $f$., fortune; la fortune, a fortune.

fossé, $m$., ditch.

fou, folle, mad; herbes folles, weeds.

fouet, m., whip ; coup de fouet, lash.

foule, $f$., crowd.

fourré, $m$., thicket.

fourrer, (to) poke, stick.

fraîcheur, $f$., freshness.

frais, fraîche, fresh, cool, blooming; du pain frais, new bread; au frais, in the cool.

franc, franc-he, frank ; moineau franc, house-sparrow. frapper, (to) knock.

frayer, (to) open; se frayer un passage, (to) make one's way, break through.

frayeur, $f$., fright; j'avais une frayeur mortelle, I was in a mortal fright.

frêne, $m$., ash tree.

friand-e, fond (of), partial (to). friandise, $f$. (generally plural in English), sweets, delicacies, dainties.

froisser, (to) offend.

front, $m$., forehead; le front blême, with a pale face.

fruit, $m$., fruit. fuite, $f$., flight.

fumée, $f$., smoke.

fumigation, $f$., fumigation.

furieu-x, - se, furious.

fussiez, subj. of être.

fut, pret. of être; il en fut de même, the same thing happened; ce qui fut long, which took a long time.

fût, subj. of être; il vaudrait peut-être mieux que ce fût toi, perhaps it had better be you.

gages, $m . p l$., wages.

gagner, (to) earn.

gai-e, gay.

gaîment, gaîly.

gaîté, $f$., gayety; avec gaîté

gayly.

galette, $f$., cake. 
galop, m., gallop; l'eau prend le galop, the water is beginning to gallop.

galopin, $m$. , urchin.

gamin-e, $m$. and $f$., child.

garantir, (to) warrant; je

garantis de les réussir, I

warrant I'll do them well.

garçon, $m$., boy.

garder, (to) keep.

gauche, adj., left.

gauche, f., left; à gauche, on

or to the left.

gavotte, $f$., gavotte.

gêner, (to) hinder; il paraît

que les soucis ne te gênent

pas toi, you don't seem to be

troubled with cares; gêné,

uncomfortable, uneasy.

généreu-x, -se, generous.

genêt, m., broom (often put in

the plural in French).

genou, $m$., knee; je me mettais

à deux genoux devant une tarte à la crême, I was ready to go on my knees before a cream tart.

gens, $m$. and $f$. pl., people, folks. gentil-le, pretty, nice.

geste, $m$., action; le regard qui

a l'air de se moquer du geste,

a look which seems a mockery of the bow.

glace, f., looking-glass, mirror, ice.

glisser, (to) slip (in).

glousser, (to) cluck. gonfler, (to) swell, inflate, distend.

gourmandise, $f$, grecdiness. goût, $m$., taste.

goûter, (to) taste; de goûter, from tasting.

grâce, $f$., favor, grace ; grâce à,

thanks to, owing to.

grain, $m$., grain.

graine, $f$., seed, eggs.

grand-e, large, big, great; huit

grands jours, eight whole

days, a whole week.

grand'mère, grandmother.

Grand Place, the central square in a city.

grand'route, $f$., high road.

grand'tante, $f$., great-aunt.

gras-se, fat.

greffe, $f$., graft, grafting.

greffier, $m$. , clerk.

grenier, $m$. , attic.

griffer, (to) scratch.

grille, $f$., bars ( $p l$.$) , grating.$

grillon, $m$., cricket (insect).

grimper, (to) climb.

grincer, (to) creak.

gris-e, grey.

grive, $f$., thrush.

gronder, (to) scold; qui gronde,

scolding.

gros, grosse, big.

guetter, (to) watch, lie in wait for.

guêtres, $f . p l$., gaiters.

gueux, m., beggar, ragamuffin, scoundrel. 
guider, (to) guide.

guilleret-te, merry.

guitare, $f$., guitar.

habit, m., coat, clothes ( $p l$.$) .$ habiter, (to) live.

habitude, $f$., habit; d'habitude, generally, usually; vous n'êtes pas comme d'habitude, you are not as usual; plus attendrie qu'à son habitude, more tender than usual. haletant-e, gasping, panting. hangar, $m$., shed, outhouse. hasard, $m$., chance ; par hasard, accidentally, as it chanced. haut-e, high, tall; de plus en plus haut, higher and higher. hélas ! excl., alas!

herbe, $f$., grass ; herbes folles, weeds.

héritage, $m$., legacy.

heure, f., hour, time; sept

heures, seven o'clock.

heureusement, fortunately.

heureu-x, -se, happy.

hirondelle, $f$., swallow.

histoire, $f$., story, tale ; toujours

dans tes histoires, (you are)

always fussing.

hiver, $m$., winter.

hochequeue, $m$., wag-tail.

homme, $m$., man.

honteu-x, -se, ashamed.

horrible, horrible.

huche, $f$., hutch, bin.

huile, $f$, oil. humeur, $f$., temper.

hurler, (to) howl.

hussard, m., hussar.

idée, $f$., idea.

il, he, it, there ; il y avait, there was; il n'y a qu'à tirer la chevillette, you need only pull the string; il nous a fallu, we had (to); il y a cinquante ans, fifty years ago. imaginer, (to) imagine, desire. immédiatement, immediately. immobile, motionless. impossible, impossible.

indici le, unutterable, unspeakable.

indienne, $f$., printed calico, print, muslin.

indigner, (to) shock ; s'indigner,

(to) become indignant.

indiquer, (to) show, point out. indulgence, $f$., indulgence ; avec

ces indulgences-là, by indulgence of that kind.

ingrat-e, ungrateful, thankless. installer, (to) settle; s'installer,

(to) install oneself.

instant, $m$., moment, instant.

instinct, $m$., instinct.

intérêt, m., interest; les intérêts, the interest.

intime, intimate, inmost, deep. invisible, invisible. invoquer, (to) call upon. irai, future of aller. irez, future of aller. 
irradier, (to) radiate; irradiés de, aureoled with. ivre, drunk, intoxicated.

jadis, formerly. jamais, never; à jamais, for ever.

jambe, $f .$, leg; le loup prit ses jambes à son cou, the wolf took to his heels; levèrent

la jambe, raised their legs. jardin, $m$., garden.

jas, m., Provençal word for farm.

je, I; j'en ai encore les doigts picotés, the pricks are still on my fingers from it.

jeter, (to) throw.

jeu, m., game; au jeu, at play. jeudi, $m$., Thursday.

jeune, young; jeune fille, (unmarried) girl.

joie, $f$., joy.

joli-e, pretty.

joue, f., cheek; jusqu'à ce qu'elle ait les joues plus rouges que son chapeau, until her cheeks were redder than her hood.

jouer, (to) play; jouer de, (to) play (an instrument); continuait à jouer, went on playing ; cessant de jouer, stopping playing; voilà bien la première fois que "Plaisir d'amour "me joue ce tour-là,

it is certainly the first time laiteu-x, -se, milky.
"Plaisir d'amour" has played me that trick. jour, $m$., day; les jours disparus, past tir.es. journée, $f$., day. joyeu- $\mathbf{x},-$ se, joyous. juge, $m$., judge.

juger, (to) try.

jusqu'à, up to, to: jusqu'à ce que, until.

juste, just; notre curé n'était patient que tout juste, our priest's patience was only just worthy of the name. justesse, $f$., justness, accuracy. justice, $f$., court of justice; ce qui me revient en toute justice, what is justly due to me.

1', see le and la.

la, def. art., $f$., the (or not to be translated; or sometimes translated by a or by the pronouns his, her, their, etc.).

there; là-bas, over there; laissant là son patient, leaving his patient (alone); làdessus, thereupon.

la, pers. pron., $f$., her, it ; met la main, put his (my, your. etc.) hand.

lâche, cowardly.

laisser, (to) leave, let, allow; ils laissèrent croire, they let it be thought.

lait, $m$.. milk. 
lambeau, m., bit, piece.

lanterner, (to) put off; peut-on se laisser lanterner ainsi, you can't allow yourself to be put off like that.

laquelle, $f$., which, what.

lard, m., bacon.

lavande, $f$., lavender.

le, def. art., m., the (sometimes not translated or sometimes by a or by the pronouns his, her, their, etc.); le dimanche, on Sunday; le soir, in the evening; l'êté, in summer; l'hiver, in winter; le matin, in the morning.

le, pers. pron., m., him, it, that. légende, $f$., legend.

légèrement, lightly, slightly.

lendemain, m., next day; le lendemain de ce jour, the day after this one.

lentement, slowly.

les, def. art., pl., the (sometimes not translated and sometimes translated by the pronouns his, her, their, etc.).

les, pers. pron., pl., them.

leste, nimble, light, clever.

lettre, $f$., letter.

leur, poss. adj., their.

leur, pers. pron., them, to

(from, for, at, on) them.

lever, (to) raise, lift up; levé, up.

liard, m., an old coin, worth a quarter of a cent. liberté, $f$., freedom.

lier, (to) bind, tie up.

lieu, m., place; au lieu de, instead of.

lire, (to) read.

lisait, imperfect of lire.

lit, $m$., bed.

litière, $f$., litter, straw.

livre, $m$., book.

livre, $f$., pound.

loi, $f$., law ; contraire aux lois, unlawfully.

loin, far; plus loin, further, farther.

l'on, people, you, we.

long, long-ue, long; au long de, le long de, by the side of, along; ce qui fut long, which took a long time.

longtemps, (a) long (time).

lorsque, when.

loup, $m$., wolf.

lourd-e, heavy.

lourdement, heavily.

lui, him, her, to him or her (sometimes not to be translated); aller lui mettre un grain de sel sur la queue, (to) go and put a grain of salt on his tail.

lui-même, himself, he, itself.

luire, (to) shine; quand luira

le jour, when the day shines.

luisaient, imperfect of luire.

lumière, $f$., light.

lunettes, $f$. $p l$., spectacles.

Lure, small chain of mountains 
in the southeast of France, a continuation of Mount Ventoux.

luth, $m$., lute.

lychnis, $m$., campion.

lyre, $f$., lyre.

m', see me.

ma, my.

magique, magic, magical.

magistrat, $m$., magistrate.

magnanerie, $f$., silk-worm nurs-

ery.

maigre, thin.

main, $f$., hand; mains de curé,

priest's hands.

maint-e, many a.

maintenant, now.

mais, but.

maison, $f$., house.

maisonette, $f$., little house.

maître, master.

maîtresse, f., mistress; la maitresse poutre, the principal beam, center beam.

mal, badly: tant bien que mal, as well as we (they) could. malade, ill.

malade, $m$. and $f$., sick person, patient.

malheur, m., misfortune ; mu-

sicien de malheur, con-

founded musician.

malheureu-x, -se, unhappy,

unfortunate, wretched man

(woman).

maiin, knowing, sharp; un malin, a sharp one; l'œil malin, with a knowing look. maman, $f$., mama, mother. manche, $f$., sleeve. mangea, pret. of manger. manger, (to) eat; avait fini de manger, had finished eating. manière, $f$., way, manner. manque, $m$., want, lack. manquer, (to) miss, fail. marché, $m$., market. marcher, (to) go ; tout marchait bien, all was going well. mari, $m$., husband.

mariage, m.; marriage.

marjolaine, $f$., marjoram. marmite, $f$., pot. marquis, m., marquis.

Martin, Saint, Bishop of Tours, in the fifth century.

masure, $f$., dilapitated house. matin, $m$., morning.

mauvais-e, adj., bad, wicked.

me, me, myself, to (for, at, from) me, to (for, at, from) myself.

méchant-e, cruel, wicked, bad, nasty.

mécréant, $m$., disbeliever, unbeliever.

mélancholie, $f$., melancholy.

mêler, (to) mix; sans qu'on s'en mêlat, without our interfering.

même, adj and adv., even, same; de même, in the same way. 
ménétrier, $m$., fiddler. mensonge, $m$., lie; il convainquit de mensonge le fermier avare, he convicted the miserly farmer of lying. merci, m., mercy, pity; sans merci, merciless, pitiless. mère, $f$., mother. mère-grand, $f$., grandmother. mérite, m., merit ; tes mérites, your deserts.

mériter, (to) deserve. merle, $m$., blackbird. merveilleu-x, -se, marvelous. messe, $f$., mass.

mesure, f., time (in music); ralentissait par trop la mesure, was playing rather too slowly.

mesurer, (to) measure, calculate.

méthode, $f$., method. mettre, (to) put (on); se mettre en route, (to) start; mettre à la raison, (to) bring to his (her, etc.) senses; plus il y mettait d'entrain, the more vigorously he did it; en me mettant au lit, as I went to bed; qu'on me mette au pain sec, let me be put on dry bread; on vous $y$ mettra certes, you shall most certainly be.

meuble; $m$., piece of furniture; meubles, furniture. meure, pres. subj. of mourir. mi-côte: à mi-côte, halfway up the hill. midi, $m$., midday, noon. miel, $m$. , honey. mieux, better, best; c'est pour mieux te voir, the better to see you with; c'est pour mieux te serrer, the better to hug you with; c'est pour mieux t'entendre, the better to hear you with.

mignon-ne, pretty, delicate, tiny, darling. milieu, $m$., middle. mille, a thousand. mince, thin, slim. minet, $m$., puss, pussy. minute, $f$., minute. miracle, $m$., miracle. mirent, pret. of mettre; se mirent à, began to. mis-e, p. p. of mettre. misérable, miserable; un vieux petit homme d'aspect misérable, a miserable-looking, little old man.

misère, f., misery, poverty ; dans la misère, destitute; avait un tel air de misère, looked so miserable.

mit, pret. of mettre; se mit à quatre pattes, went on all fours; se mit à, began to ; mit pied à terre, alighted. modéré, moderate. modeste, modest, moderate. moi, I, me (sometimes only used 
for emphasis, not to be translated).

moineau, $m$., sparrow ; moineau franc, house-sparrow.

moins, less; au moins, du moins, at least, at any rate.

mois, m., month.

moitié, $f$., half.

mollet, m., calf (of the leg); œufs mollets, boiled eggs (which are neither soft nor hard but between the two).

moment, m., moment, time, à ce moment-là, just then, au moment où, just when.

mon, my.

monde, m., world; le pauvre monde, the poor; tout le monde, everybody.

monnaie, $f$., coin, money.

monsieur, sir (often at the be-

ginning of the sentence in French, when we should put Sir in the middle or at the end); Monsieur le juge, My Lord.

montagne, $f$., mountain, mountains.

montée, f., ascent; à mimontée, halfway up.

monter, (to) get up, go up, mount; se monter, (to) amount.

montrer, (to) show.

se moquer (de), (to) laugh at;

le regard qui a l'air de se moquer du geste, a look which seems a mockery of the bow.

mordre, (to) bite. mortel-le, mortal.

mot, m., word; je te prends

au mot, I'll take your word for it.

mouche, $m$., fly.

moucher, (to) blow the nose of ;

se moucher (de), (to) blow one's nose (with).

mouchoir, $m$., handkerchief.

moudre, (to) grind.

mouiller, (to) wet.

moulu, $p$. $p$. of moudre, bruised

all over.

mourir, (to) die, be dying.

mourut, pret. of mourir.

mousse, $f$., moss.

mousseu-x, - se, sparkling.

multiplier, (to) multiply.

munir (de), (to) provide (with).

mur, m., wall.

mûr-e, ripe.

mûrier, $m$., mulberry tree.

musette, $f$., pipe, bagpipe.

musicien, $\cdot m$., musician ; mu-

sicien de malheur, confounded musician.

musicien-ne, musical; je ne vous savais pas musicien, I did not know you were musical.

musique, $f$., music.

myrte, $m$., myrtle.

mystérieu-x, -se, mysterious, obscure. 
n', see ne.

nageur, $m$., swimmer. naif, naive, simple, artless, naïve.

nain, $m$. , dwarf.

naissent, pres. ind. of naître.

naître, (to) be born.

naiveté, $f$., artlessness.

nappe, $f$., cloth.

navrer, (to) grieve most deeply ;

le cœur navré, almost heartbroken.

ne, neg. particle used mostly with pas, personne, jamais, etc., not; n'avait pas de nom, had no name.

nécessaire, necessary.

n'est-ce pas? isn't it? mustn't they? is it not so?

net, $a d v$., right off, at once.

neuf, neuve, new.

nez, $m$., nose.

ni ... ni, neither ... nor; ni le chou non plus, neither had the cabbage; ils ne parlèrent ni l'un ni l'autre, they neither of them spoke.

nœud, $m$., knot; des nœuds de frêne, knots in ash wood.

noir, black; dans le cabinet

noir, in the dark.

nom, $m$., name.

nommer, (to) name, call. non, no; ni le chou non plus, neither had the cabbage.

nos, our. notre, our (sometimes translated the).

nourrir, (to) nourish, cherish, foster.

nourriture, $f$., food.

nous, we, us, ourselves; il nous a fallu, we had (to). nouveau, nouvelle, new; de nouveau, again.

nuance, $f$., shade. nuée, $f$., cloud. nuit, $f$, night.

obéir (à), (to) obey.

obéissait (à), imperfect of obéir. obliger, (to) oblige, force.

obscur-e, obscure.

obtenir, (to) obtain.

occasion, $f$., occasion.

œil, $m$., eye.

œuf, m., egg.

officier, $m$., officer.

offrir (à), (to) offer, give ;

Seigneur, je vous l'offre,

for Thy sake, Lord.

oiseau, $m$., bird.

oiselet, $m$., little bird.

ombre, $f$., shade, dark.

on, people, they, some one, we; on entendit du bruit, a noise was heard; on payait mal ses services, he was bein $;$ badly paid for his services: il faut croire qu'on se faic vieille, I suppose I am getting old; peut-on se laisser lanterner ainsi ! you can't allow 
yourself to be put off like that! on le conduisait, he was being taken; on rendit à Jean, Jean was given back; on l'avait dépouillé, he had been stripped; on le suspendit, he was hung up.

once, $m$., ounce.

oncle, $m$., uncle.

ongle, $m$, nail.

opération, $f$., operation.

or, m., gold; d'or, golden.

orage, $m$., storm.

- oreille, $f$., ear.

original-e, original.

orner, (to) decorate.

oser, (to) dare; sans trop oser

rien dire, without much dar-

ing to say anything.

ôter, (to) take away.

ou, or.

où, where, when, in which, on which.

oublier, (to) forget.

ouvrage, $m$., work.

ouvrir, (to) open; s'ouvrir,

(to) open.

païen, $m$., pagan, heathen.

paille, $f$., straw.

pain, $m$., bread.

panier, $m$., basket.

papa, m., papa.

par, by, in, on, through; par

suite de, owing to; par an,

par année, a year; par hasard, accidentally, as it chanced; par trop, rather too much.

paraissaient, imperfect of paraître.

paraissait, imperfect of paraître. paraît, pres. ind. of paraître; il paraît que les soucis ne te gênent pas, toi, you don't seem to be troubled with cares. paraître, (to) appear, seem.

parce que, because.

pardonner, (to) forgive.

pareil-le, like, similar.

pareillement, in like manner,

likewise.

parfumer, (to) perfume, scent; parfumé, full of scent.

parler, (to) speak, talk.

parmi, among.

part, $f$., share; - de toutes parts, on all sides; à part soi, to himself, within himself; de notre part, from us; à part moi, to myself.

parti, $m$. , decision.

particuli-er, -ère, peculiar (to).

partie, $f$., part.

partir, (to) go off.

partout, everywhere.

parut, pret. of paraître.

pas, negative with or without ne,

not, no; n'avait pas de nom,

had no name.

pas, $m$., step.

passage, m., passage, way; se frayer un passage, (to) make one's way, break through. 
passant, m., passer-by. passé, adj., past; mes huit printemps passés d'avril, my eight years last April. passé, prep., beyond. passer, (to) pass, go, go down, disappear; se passer de, (to) do without.

Pater, m., name for Lord's

Prayer in Latin.

patient, $m$., patient; notre curé n'était patient que tout juste, our priest's patience was only just worthy of the name.

pâtissier, m., confectioner, pastry-cook.

patte, $f$., paw, foot, leg; se mit

à quatre pattes, went on all fours.

pâturage, $m$., pasture.

pauvre, poor ; le pauvre monde, the poor; pauvres au fond, although they were in the main poor.

payer, (to) pay (for).

pays, $m$., country, countryside. paysan, $m$., peasant; des pay-

sans, country people.

pêche, $f$., peach.

péché, $m$., sin.

peine, $f$., trouble, difficulty. pelisse, $f$., pelisse.

pendant, for; pendant que,

while.

pendre, (to) hang.

penser, (to) think, imagine.

pente, $f$., slope. percher, (to) perch.

perdre, (to) lose.

perdu, p. p. of perdre, out of the way; vous vous êtes perdus? have you lost your way?

permettait, imperfect of permettre.

permettez, pres. ind. and imperative of permettre; ne le permettez pas, don't allow him to.

permettre, (to) allow.

perse, $f$., chintz.

personne (ne), no one, not any one.

personne, $f$., person.

perte, $f$., loss, ruin.

peser, (to) weigh.

petit-e, little, small; au petit bonheur, as well as we could; au petit trot, at a jog trot.

peu, little; avant peu, in a short time; peu à peu, little by little; se soucier peu de, not (to) care much about.

peuple, $m$., people, nation.

peuplier, $m$., poplar.

peur, $f$., fear ; j'avais eu peur,

I had been afraid.

peut-être, perhaps.

peux, pres. ind. of pouvoir, can, may.

philippique, f., philippic (discourse full of invective).

picoter, (to) prick.

pied, m., foot; sur pied, on 
one's (my, your, etc.) feet, up ; mit pied à terre, alighted. pierraille, f., pebbles, broken stones.

pincer, (to) pinch, nip.

pinson, $m$., finch, chaffinch.

pipe, $f$., pipe.

piquer, (to) prick; piqué de mousses, dotted with mosses. pis, $a d v$., worse; tant pis, so much the worse (for us), it couldn't be helped.

pitié, $f$., pity ; c'était pitié, it was pitiful.

place, f., room, place; sur place, on the spot; à la place de, instead of.

plaignant, pres. part. of plaindre. plain-e, level, flat; s'ouvrant de plain-pied sur un jardin, opening straight on to a garden.

plaindre, (to) pity ; se plaindre, (to) complain.

plaisanter, (to) joke, chaff ; Anselme plaisanté amicalement, Anselm who was chaffed in a friendly way.

plaisir, m., pleasure; Plaisir d'amour, is the name of a well-known old eighteenth-century song.

planche, $f$., shelf.

plateau, $m$., scale.

plein-e, full; en plein Angelus de midi, right in the middle of the day, at the noon An- gelus; en pleine forfaiture, in the very midst of her crime.

plus, more, most; ni le chou non plus, neither had the cabbage; je ne sais plus quoi, I do not know what else; de plus, besides, else; plus . . . plus, the more . . . the more; plus de tarte à la crême, no more custard tart; ça ne va donc plus finir, will they never be done; et je n'y pensais seulement plus, I had forgotten all about it; ne .. . plus, no longer, not any longer (this expression is not necessarily always translated); de plus en plus, higher and higher; je ne sais plus le goût qu'ont les poires, I have quite forgotten the taste of the pears; n'attendaient plus que les cocons, were now only waiting for the cocoons.

poche, f., pocket; violon de poche, pocket violin.

pochette, $f$., little pocket, pocket violin.

poignet, $m$., wrist.

point, $m$., point; à quel point vous êtes faible, how weak you are; cuits à point, cooked to a turn.

point, $a d v$. : point ne fut besoin de me battre, there was no 
need to beat me; ne lui donna point de gages, did not give him any wages; point n'est besoin que je le dise, there is no need for me to say so.

poire, $f$., pear.

poli-e, polite, polished, sleek; ses belles mains de curé douces et polies par les bénédictions, his beautiful soft priest's hands made sleek with blessing.

poliment, politely. pollen, $m$., pollen. pomme, $f$., apple. populaire, popular.

portant-e: bien portants, in good health.

porte, $f$., door. porter, (to) take, carry, bear (fruit).

portrait, $m$., portrait.

poser, (to) place.

positivement, positively.

posséder, (to) possess.

possible, possible; le plus pos-

sible, as much as possible. posture, $f$., position.

pot, $m$., pot.

potence, $f$., gallows.

pouce, $m$., thumb.

poule, $f$, hen.

pour, to, for; pour troisième don, for his third gift; pour que (followed by subjunctive), in order that, so that, for
. . to ; pour qu'elle eût le temps, for her to have the time.

pourquoi, why, what for.

pourrait, cond. of pouvoir; on pourrait en tirer un bon prix, a good price could be got for it.

pourras, future of pouvoir.

pourriez, cond. of pouvoir, might. poursuivit, pret. of poursuivre; poursuivit gaîment son chemin, he went gaily on his way.

poursuivre, (to) pursue. pourtant, yet, still, all the same; on ne peut pourtant pas avoir, you can't very well have. pousser, (to) utter, come out, push.

poussière, $f$., dust.

poutre, $f$., beam, rafter.

pouvait, imperfect of pouvoir, could; n'en pouvait plus, was quite exhausted; ne le pouvait pas, could not do it. pouvoir, (to) be able. pouvoir, $m$., power. prairie, $f$., meadow. pré, $m$., field, meadow. précisément, exactly. précipiter, (to) fling down; se précipiter, (to) fall headlong; de se précipiter, of falling headlong.

préférer, (to) prefer.

prêluder, (to) preclude; Cou- 
sine Annette préludait,|prison, $f$., prison.

Cousin Annette played the opening bars.

premi-er, -ère, first.

prend, pres. ind. of prendre;

l'eau prend le galop, the water is beginning to gallop.

prendre (à), (to) take (from), capture, get; prendre une décision, (to) make a decision; prendre garde à, (to) beware of.

prends, pres. ind. and imperative

of prendre; eh bien, je te prends au mot, oh well, I'll take your word for it. préoccupé, anxious, worried. près (de), near, nearly. présomption, $f$., presumption. présomptueu- $\mathbf{x},-$ se, presump-

tuous.

presque, nearly, almost.

presser, (to) be urgent ; pressé,

in a hurry ; l'avare n'eut rien de plus pressé que, the miser had nothing better to do than. prêt-e, ready.

prêter, (to) lend.

prier, (to) pray (to).

prière, $f$., prayer.

printemps, m., spring; mes

huit printemps, my eight

years.

prirent, pret. of prendre.

pris, pret. of prendre.

pris, $p . p$. of prendre.

prise, f., pinch (of snuff).

prisonnier, $m$., prisoner.

prit, pret. of prendre; le loup

prit comme on dit ses jambes

à son cou, the wolf took to his heels as they say; on prit le sage parti de, we wisely decided to.

prix, m., price.

procédé, $m$., proceeding.

prochain-e, next.

profond-e, profound.

programme, $m$., program, plan. promettait, imperfect of promettre.

promettre, (to) promise.

promis, p. p. of promettre.

protestation, $f$., protest.

protester, (to) protest, make objections.

prouver, (to) prove.

providentiel-le, providential.

province, $f$., province; coin de

province, secluded country-

place.

provision, $f$, provision, supply. puis, then.

puiser, (to) draw up, take.

puisque, since, as.

put, pret. of pouvoir, could.

qu', see que.

quand, when; quand même, all the same.

quant à, as for, as to.

quart, m., quarter; quart d'heure, quarter of an hour. 
quatre, four; quatre à quatre, four steps' at a time. que, conj., that (or not always necessarily translated), than; (to avoid repetition of other conjunctions) because, as, etc.; ne ... que, only; il n'y a qu'à tirer la chevillette, you need only pull the string; même il n'en fit qu'une bouchée, he even swallowed her at a single mouthful; ne parlèrent que du voyage, talked of nothing else but the excursion; ce n'était pas précisément chose commode que d'atteindre, it was not exactly easy to reach; tant bien que mal, as well as they (we, etc.) could.

que, rel. pron., that, whom, which.

que, int. or excl. adv. and pron., what; que ne donnerais-je pas, what would I not give. quel-1e, what, which. quelconque, whatever, of some kind.

quelque-s, some, a few. quelqu'un, somebody, any one. quenouille, $f$., distaff. queue, $f$., tail. qui, who, whom, that, which; un écu à qui m'attachera solidement, a crown to any one who will tie me up stoutly; bon pour vous qui vous en allez tranquillement sur votre âne, it's all very well for you going quietly along on your donkey.

quitter, (to) leave, put down, give up.

quoi, what, which; je ne sais plus quoi, I do not know what else; eh quoi! what then! de quoi, something, wherewith.

quoique, although.

raidillon, $m$. , up-hill road, steep hill.

raison, $f$., reason; mettre à la raison, (to) bring to his (her, etc.) senses.

ralentir, (to) slacken; ralentissait par trop la mesure, was playing rather too slowly.

ramasser, (to) pick up; allez ramasser, go and pick up.

ramener, (to) bring back; me ramenait sur son chemin, brought me back towards it. rang, $m$., row.

ranger, (to) put in order, arrange, draw up; se ranger, (to) step aside. rapport, $m$., connection. rassasié, satisfied, satiated. rayon, $m$., ray ; miel en rayon, honey in the comb. rayonnement, $m$., radiation. recevez, pres. ind. and imperative of recevoir; recevez mes 
compliments, I congratulate you.

recevoir, (to) receive, get. recevras, future of recevoir. réclamer, (to) protest. récompenser, (to) reward. se récrier, (to) cry out. reçu, $p$. p. of recevoir. reculer, (to) move back; faire reculer, (to) move back. récuser, (to) challenge; se récuser, (to) decline, draw off. redescendre, (to) come down again, go down again. reflet, $m$. , reflection; des reflets, light and shade. réflexion, $f$., reflection; réflexion faite, all things considered.

refrain, $m$., refrain, chorus. rêfugier, (to) take refuge; réfugié, who had taken refuge. refuser, (to) refuse.

régaler, (to) treat (to); se régaler (de), (to) feast (upon). regard, $m$. , look; le regard au ciel, looking up to the sky (heaven).

regarder, (to) look (at); ne me regarde pas, is no affair of mine.

régler, (to) settle, dispatch. régner, (to) reign.

regret, $m$., regret.

relever, (to) turn up; se relever, (to) get up again, stand up. remercier, (to) thank.

remettre, (to) hand; se remettre, (to) recover; se remettre en route, (to) go on one's way.

remit, pret. of remettre.

remonter, (to) get up ... again; remontant le courant des jours disparus, going back over past times.

remplir, (to) fill; se remplir (de), (to) get filled (with). remuer, (to) move.

renâcler, (to) hang back, draw back; se renâcler devant, (to) grumble at.

rendre, (to) give back, return; on rendit à Jean, Jean was given back; tu as suffisamment écorché le pauvre monde que les épines te le rendent, you have fleeced the poor long enough, now the thorns shall fleece you; se fit rendre la sarbacane, got back the pea-shooter. se rengorger, (to) bridle up. rente, $f$., revenue; de petites rentes, a small income; de ces toutes petites rentes, one of those very small incomes.

rentrée, f., reopening; firent leur rentrée dans, reëntered. répandre, (to) spread around. reparaître, (to) reappear. repas, m., meal. 
répéter, (to) repeat, say ... again.

répondre, (to) reply.

repos, $m$., rest.

reposer, (to) put down again;

se reposer, (to) rest.

reprendre (à), (to) reply, rejoin, go back to, resume, take back (from); pour bien se reprendre à la vie, (to) make another good start in life.

représenter, (to) represent. reprit, pret. of reprendre. réseau, m., net, network, wirework.

résigner, (to) resign. résolut, pret. of résoudre. résolution, $f$., resolution. résoudre, (to) resolve.

respect, $m$., respect.

respectueu-x, -se, respectful. ressembler (à), (to) look like,

resemble.

restant, $m$., remains, remainder. reste, $m$., remainder, rest; du reste, but however, nevertheless.

'rester, (to) stay, remain; son corsage restait souple et mince, her bodice was still soft and slim.

résultat, $m$., result. retenait, imperfect of retenir. retenir, (to) keep. retirer, (to) take off, remove. retour, m., return; à chaque retour d'avril, every time April came round.

retourner, (to) go back; se retourner, (to) turn (round); pour que je m'en retourne vers Azay, for me to go back to Azay.

retrousser, (to) turn up, tuck up.

réussir, (to) succeed, be a success; je garantis de les réussir, I warrant I'll do them well.

réussite, $f$., success ; la réussite était bonne, they were a great success.

revanche, $f$., revenge.

rêve, $m$., dream.

revenir, (to) come back, accrue,

be due, return.

revenu, $m$., income.

rêver, (to) dream (of).

reviennent, pres. ind. of revenir; qui s'en reviennent en voiture, driving back.

revient, pres. ind. of revenir.

ricaner, (to) grin, sneer.

rideau, $m$., curtain.

rien, anything, nothing; pour rien au monde, not for anything in the world; je n'y comprends rien, I don't understand it.

rillettes, $f . \quad p l .$, a particular preparation of minced pork made in Touraine.

rire, (to) laugh, chuckle. 
risque, $m$. , risk.

rivière, $f$., river.

roche, $f$., rock.

rocher, $m$., rock.

rogner, (to) pare, cut, chip.

rôle, $m$., part.

romance, $f$., ballad, song.

ronce, $f$., bramble, briar.

rose, $f$., rose; rose trémière,

hollyhock.

rossignol, $m$., nightingale.

roue, $f$., wheel.

rouge, red.

rougeâtre, reddish.

rouler, (to) rumble along, roll;

cailloux roulés, shingle of round stones.

route, $f$., way, road; se mettre

en route, (to) start.

roux, rousse, red, ruddy.

ruisseau, $m$., stream.

rustre, $m$., boor.

s', see se and si.

sa, his, her, its.

sable, $m$., sand,

sablier, $m$., sand-glass, hour-

glass.

sachant, pres. part. of savoir.

sage, good.

saint-e, holy.

sais, pres. ind. of savoir; je ne

sais plus le goût qu'ont les

poires, I have quite forgotten

the taste of the pears.

saisir, (to) seize.

saisissant, pres. part. of saisir. sait, pres. ind. of savoir.

salon, $m$., drawing-room.

salut, m., bow, salvation.

sanguinaire, bloodthirsty.

sans, without; sans doute,

doubtless, probably; sans

cela, otherwise, but for that.

sarbacane, $f$., pea-shooter.

satisfaire, (to) satisfy.

saurai, future of savoir, can.

saurez, future of savoir.

sauter, (to) jump.

savais, imperfect of savoir; je

ne vous savais pas musicien,

I did not know you were a musician.

savait, imperfect of savoir.

savant, $m$., scientist.

savant-e, adj., learned, wellinformed, clever.

savoir, (to) know (how to),

know ... (to be); sans le

savoir, without knowing it.

scélérat, $m$., wretch, villain, scoundrel.

se (often not to be translated), himself, herself, itself, themselves.

sec, sharp, gaunt, dry.

sécateur, $m$., pruning scissors.

second-e, adj., second.

seconde, $f$., second.

s'écrier, see écrier.

seigneur, m., lord, Lord.

sel, $m$., salt.

selon, according to.

semaine, $f$., week. 
sembler, (to) seem.

s'en aller, see aller.

s'en venait, see venait.

sentier, m., path, track.

sentiment, m., sentiment, "feeling.

sentir, (to) feel; se sentir, (to)

feel.

sera, future of être.

serais, conditional of être.

serait, conditional of être.

seront, future of être.

serpolet, $m$., wild thyme.

serrer, (to) hug, squeeze; se

serrer, (to) squeeze.

service, $m$., service.

servir, (to) serve; dont il se

servit encore, which he used again.

ses, his, her, its.

seul-e, alone.

seulement, only, even; je n'y

pensais seulement plus, I

had forgotten all about it.

si, $a d v$., so, such; si bien que,

so that.

si, conj., if.

sien-ne (le, la), his (own), her (own).

sieste, $f$., siesta; faire un bout

de sieste, (to) take a little nap. siffler, (to) whistle.

silencieusement, silently, in silence.

simple, simple, easy; simple d'esprit, simple-minded. simplement, simply, merely. singuli-er, -ère, singular, extraordinary.

sinistre, sinister, forbidding, ominous.

sinon, if not.

société, $f$., society; le salut de

la société, social salvation.

sœur, $f$., sister; sœur tourière,

lay-sister.

soi, him, oneself, himself.

soie, f., silk; vers à soie, silk

worms.

soigneusement, carefully.

soin, $m$., care, task.

soir, m., evening.

sois, imperative and subjunctive

of être, be.

soleil, m., sun.

solide, strong, firm, stout; solides comme, as firm as. solidement, firmly, stoutly.

somme, $f$., sum; cela fait une

somme, that makes a good round sum; mais c'est une somme, it's a big sum of money.

sommeil, m., sleep.

sommes, pres. ind. of être;

sommes-nous bêtes, how silly

we are.

son, his, her, its (sometimes

translated the).

songer (à), (to) think (of).

sonner, (to) ring, jingle.

sonore, echoing, ringing.

sont, pres. ind. of être.

sorte, $f$., sort, kind. 
sortir, (to) go out, come out, get out; tu sortiras, you shall come out; ce n'est pas Biquette qui est sortie du chou, it was not Biquette who came out of the cabbage; d'où sortait un peu de fumée, out of which there came (issued) a little smoke; en sortant de table, on leaving the dinner table, after dinner.

sou, $m$., cent.

souci, m., care; il paraît que

les soucis ne te gênent pas, toi, you don't seem to be troubled with cares. se soucier de, (to) care about. soudain, suddenly. souhait, m., wish. soulager, (to) relieve. soulever, (to) hold up, bear up, raise. souper, (to) have supper, sup. soupirer, (to) sigh. souple, soft. source, $f$., spring. sourire, (to) smile. sous, under, beneath. souvenir, m., memory, remembrance, keepsake, souvenir. souvent, often. sphinx, $m$., sphinx. stratagême, m., stratagem. stupeur, f., stupor; Stupeur ! Great heavens! suer, (to) perspire. suffire, (to) be enough. suffisaient, imperfect of suffire. suffisamment, enough. suis, pres. ind. of être. suite, f., continuation; par suite de, owing to; tout de suite, immediately.

suivant, according to ; suivant son cœur, after his own heart. suivre, (to) follow.

sujet, $m$., subject; au sujet de, about.

superbe, superb, full of pride. supplément, m., supplement; un supplément de revenu, an addition to their income. suprême, supreme, crowning. sur, to, onto, on, at, upon, up ; sur pied, on our (my, etc.) feet.

sûr-e, sure; à coup sûr, to a certainty, certainly. surcroît, $m$., increase. surtout, especially. surveiller, (to) keep an eye on. survenir, (to) come on, arise, occur. survenu, past part. of survenir; est survenu, occurred. suspendre, (to) hang up; on le suspendit, he was hung up. sut, pret. of savoir.

t', see te.

ta, thy, your. tabatière, $f$., snuff-box. table, $f$., table; table à ouvrage, work-table. 
tabouret, $m$., stool.

taille, $f$., figure, shape, size. tailler, (to) cut, shape, prune. taire, not to say, say nothing of ; fais taire cette musique $d u$ diable, make that devil's music stop, stop that devil's music. talus, $m$., bank, slope. tambourin, $m$., tambourine. tandis que, while, whilst. tant, so much, so many; tant bien que mal, as well as they could; tant pis, so much the worse (for us), it couldn't be helped; tant que, as long as, so long as.

tantôt, by and by; tantôt . . . tantôt, now .. now, sometimes . . sometimes.

tantôt, $m$., afternoon.

tard, late; tôt ou tard, sooner or later.

tarte, f., tart; tarte à la crême, custard tart.

tas, $m$., heap.

te, thee, you, to you (sometimes not translated), for you, yourself.

tel-le, adj., such; avait un tel air de misère, looked so miserable.

temple, $m$., temple.

temps, m., time, weather; des personnes de l'ancien temps, old-fashioned people; de temps en temps, from time to time. tendre, (to) pass, hand, hold out, hang. tenir, (to) hold, keep (on). terme, m., term; dans toute la force du terme des personnes de l'ancien temps, thoroughly old-fashioned people.

ternir, (to) tarnish, dull, dim; les glaces lentement ternies, the mirrors which had slowly been tarnished.

terre, $f$., earth, land; mit pied à terre, alighted.

tes, adj. pl., thy, your.

tête, f., head; le juge et le fermier en tête, headed by the judge and the farmer; en tête à tête, all alone. tiens, pres. ind. and imperative of tenir.

tiens ! interjection, here! timide, shy.

tiroir, m., drawer.

tirer, (to) draw, pull (out); on pourrait en tirer un bon prix, a good price could be got for it. toi, thee, you (often added for emphasis, not necessarily translated). toit, $m$., roof. tomber, (to) fall. tonnelle, $f$., arbor. tonner, (to) thunder; qui tonne, thundering. tonnerre, $m$., thunder.

tort, m., wrong; avoir tort, (to) be wrong. 
tôt, soon, early; tôt ou tard, sooner or later.

total, $m$., total, whole. toucher, (to) touch, receive. touffe, $f$., tuft, clump. toujours, always, still. tour, m., turn, trick.

Touraine, $f$., old name of one of the central provinces of France, now formed into the department of Indre-et-Loir.

tourière, $a d j$. : sœur tourière, lay-sister.

tourmenter, (to) torment. Tours, old capital of Touraine, on the Loire.

tous, adj. and pron., m. sing., all, everything; tous les deux, both; tous les, every. tout, adj. and pron., m. sing., all, everything; tout le monde, everybody; une absence de tout un jour, a whole day's absence.

tout, $a d v$., all, quite, very, right ; tout à coup, all of a sudden, suddenly ; tout d'abord, first, foremost; tout au contraire, on the contrary; tout de suite, immediately; tout de même, all the same.

toute(s), pron. and adj., f., all ; toutes deux, both; de ces toutes petites rentes, one of those very small incomes; toute la vie, all life long; à toute extrémité, dying. tracas, $m$., worry.

tracasser, (to) worry.

train, m., train; en train de

filer, who was spinning; en train de, in the act of.

tranquille, quiet; laisse donc

les arbres tranquilles, do

leave the trees alone.

tranquillement, quietly.

transformer, (to) transform.

transparent-e, transparent.

travail, $m$., work.

travailler, (to) work.

travers, $m$. : à travers, across,

through; en travers $\mathbf{d u}$, crosswise (on), across.

traverser, (to) cross, traverse.

treillage, m., trellis, trellis

work.

tremblant-e, trembling.

trémière, $a d j$. : rose trémière,

hollyhock.

très, very.

trésor, m., treasure.

triomphalement, triumphantly.

triompher, (to) triumph.

triste, sad.

trompette, $f .$, trumpet; avec

un bruit de trompette, as

loud as a trumpet.

tronc, m., trunk.

trop (de), too, too much, too

many, much.

trot, m., trot; au petit trot, at

a jog trot.

trotter, (to) trot; voilà donc notre petite fille qui trotte, 
qui trotte, and so the little girl trotted off.

trotteu-r, -se: aiguille trotteuse, second-hand (of $a$ watch).

trouver, (to) find; se trouver,

(to) find oneself, be, happen

to be; ils se trouvèrent, they were, as it happened.

tu, past part. of taire; et Ma-

dame Peyrolles s'étant tue, and as Madame Peyrolles stopped talking.

tu, thou, you.

tuer, (to) kill.

tyran, $m$., tyrant.

un, une, a, an, one; une fois, once.

unir, (to) link.

utile, useful.

va, pres. ind. and imperative of aller, is going to, will; va-t-en, be off.

vais, pres. ind. of aller, will.

valet, m., servant, (serving) man.

valeur, $f$., value.

valoir, (to) be worth.

vanter, (to) praise.

vas, pres. ind. of aller, will;

tu vas t'en aller, you must go and; vas-tu? are you going?

vaudrait, cond. of valoir; il vaudrait peut-être mieux que ce fût toi, perhaps it had better be you.

venait, imperfect of venir; qui s'en venait en face de lui, who was coming towards him.

venir, (to) come (and); que vois-je venir, what do I see coming.

vent, $m$., wind.

ver, m., worm; vers à soie, silk-worms.

ver, $m$., verse.

vers, to, towards.

vert, green.

vêtements, $m . p l$., clothes.

veux, pies. ind. of vouloir, will,

want; que veux-tu? what would you have? ce que je veux dire, what I mean.

veut, pres. ind. of vouloir, will (sometimes translated by the past, would).

vibrer, (to) vibrate.

vide, empty.

vie, $f$., life.

vieille, $f$., old.

vieillir, (to) grow old, make older.

vieux, adj., m., old.

vieux, $m$., old man; les deux

vieux, the two old people.

vigne, $f$., vine.

village, $m$., village.

ville, $f$., city, town.

vîmes, pret. of voir.

vin, $m$., wine. 
violon, $m$., violin .

visage, $m$., face.

viser, (to) take aim at.

visiter, (to) visit.

visiteur, $m$., visitor.

vit, pret. of voir.

vite, quickly.

vitre, $f$., pane of glass ; la glace

feuilletée en vitres, the thin

layers of ice.

vivant, lively.

vivant, $m$., living creature.

vivement, briskly, vigorously,

sharply.

vivre (de), (to) live (on).

vli! vlan! slap! bang!

vœu, $m$., wish.

voici, here is, here are.

voilà, there are, there is, it is

(sometimes not to be trans-

lated); mais voilà que le chien ne veut pas mordre Biquette, but lo and behold! the dog would not bite Biquette; voilà pourtant deux mois que nous nous exterminions. vet we had been wearing ourselves out for two months; voilà que, and then; voilà deux années de cela, that is two years ago. voir, (to) see; se voir, (to) be seen ; fit voir, showed. vois, pres. ind. of voir. voisin-e, $m$. and $f$., neighbor; plus voisin de, nearer to. voiture, f., carriage, cart, ve- hicle ; qui s'en reviennent en voiture, driving back.

voix, $f$., voice.

voler, (to) steal (something), rob (some one).

volière, $f$., aviary, bird-cage. volontiers, willingly, gladly;

que volontiers elle montrait, which she liked to show.

vomir, (to) pour forth.

vont, pres. ind. of aller.

votre, your.

voudrais, cond. of vouloir.

voudras, future of vouloir; tout

ce que tu voudras, all you

want, (I will accept) any-

thing you like.

voudriez, cond. of vouloir.

voulait, imperfect of vouloir, would, wanted.

vouloir, (to) want, like, be willing.

voulu, past part. of vouloir.

vous, you.

Vouvray, small city in Touraine, known for its sparkling wine. voyage, m., journey, trip, excursion.

voyageur, m., traveler, wayfarer.

voyaient, imperfect of voir; se voyaient, were seen, you could see.

voyais, imperfect of voir.

voyez, pres. ind. of voir; non, mais vous voyez ça d'ici, just fancy what it was like. 


\section{VOCABULARY}

vrai-e, real, true; maman disait $\mid \mathrm{y}, a d v$. and pron., there, about vrai, mamma told the truth. it (often not to be translated); vraiment, really.

vu, past part. of voir; j'ai vu,

I saw.

vue, $f$., view. il y avait, there was; il $y$ a cinquante ans, fifty years ago.

yeux, m. pl., eyes. 







\section{CIRCULATION DEPARTMENT 198 Main Stacks}

\begin{tabular}{cc|l|l}
\hline $\begin{array}{c}\text { LOAN PERIOD } \\
\text { Home Use }\end{array}$ & 1 & 2 & 3 \\
\hline & 4 & 5 & 6 \\
\hline
\end{tabular}

\section{ALL BOOKS MAY BE RECALLED AFTER 7 DAYS.}

Renewals and Recharges may be made 4 days prior to the due date. Books may be renewed by calling 642-3405.

\section{DUE AS STAMPED BELOW.}

\begin{tabular}{l|l|l}
\hline & & \\
\hline & & \\
\hline & & \\
\hline A 9,9 & 9005 & \\
\hline
\end{tabular}




\section{YA 00216}

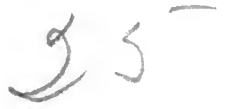

$\overline{\mathrm{M}} 442: 35$

$803 d$

$M 152$

PY

THE UNIVERSITY OF CALIFORNIA LIBRARY 
t. 